\title{
Recent Changes in U.S. Family Finances: Evidence from the 2001 and 2004 Survey of Consumer Finances
}

Brian Kı Bucks, Arthur B. Kennickell, and Kevin B. Moore, of the Board's Division of Research and Statistics, prepared this article with assistance from Gerhard Fries and A. Michael Neal.

The Federal Reserve Board's Survey of Consumer Finances for 2004 provides insights into changes in family income and net worth since the 2001 survey. The survey shows that, over the 2001-04 period, the median value of real (inflation-adjusted) family income before taxes continued to trend up, rising 1.6 percent, whereas the mean value fell 2.3 percent. Patterns of change were mixed across demographic groups. These results stand in contrast to the strong and broad gains seen for the period between the 1998 and 2001 surveys and to the smaller but similarly broad gains between the 1995 and 1998 surveys (figure 1).

Much like median income, median real family net worth in the 2001-04 period increased 1.5 percent, but mean net worth rose 6.3 percent. The increase in wealth appears to have been clearest in the middle income group. Over many other demographic groups, the data show a complex pattern of mixed increases

1. Change in median and mean incomes, 1995-2004 SCF

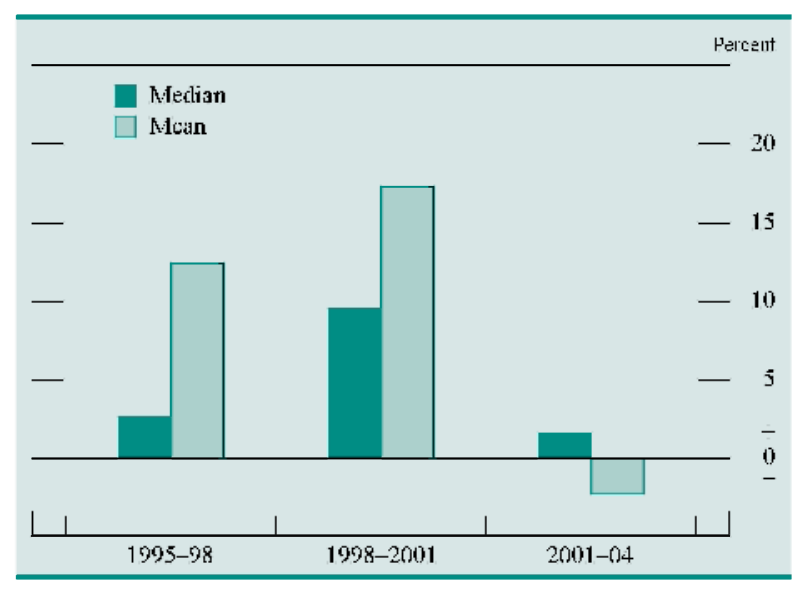

Source: Federal Reserve Board, Survey of Consumer Finances.
2. Change in median and mean net worth, 1995-2004 SCF

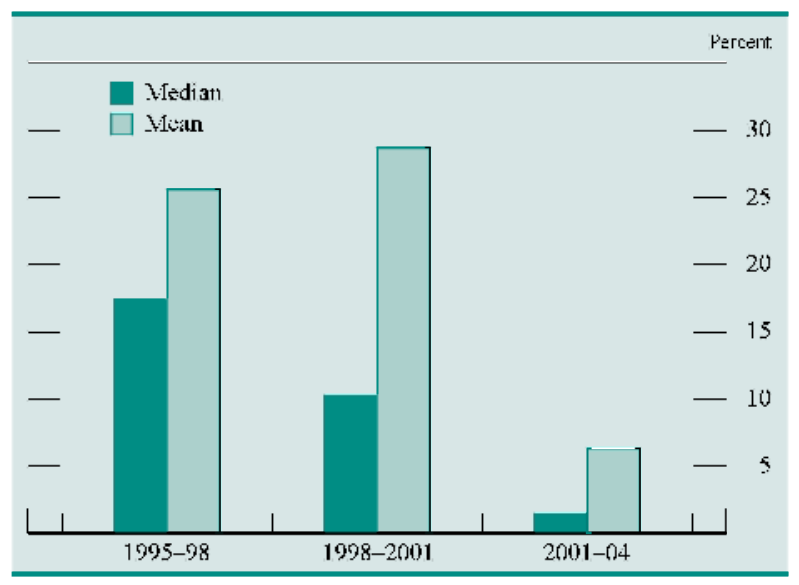

SOURCE: Federal Reserve Board, Survey of Consumer Finances.

and decreases in wealth; in some instances, median and mean values moved in opposite directions, a pattern that signals distributional changes within groups. In contrast, the growth in wealth between the 1998 and 2001 surveys and between the 1995 and 1998 surveys was stronger both in the mean and in the median, and the growth was shared by most demographic groups (figure 2).

Three key shifts in the 2001-04 period underlie the changes in net worth. First, the strong appreciation of house values and a rise in the rate of homeownership produced a substantial gain in the value of holdings of residential real estate. Second, despite the general recovery of prices in equity markets since 2001, the direct and indirect ownership of stocks declined, as did the typical amount held. Third, the amount of debt relative to total assets increased markedly, and the largest part of that increase was attributable to debt secured by real estate.

As debt rose over the period, families devoted more of their incomes to servicing their debts, despite a general decline in interest rates. Also, the fraction of families with large required debt service payments relative to their incomes rose a small amount, and the 
fraction of families that had payments that were late sixty days or more in the year preceding the survey rose more substantially. These increases affected mainly the bottom 80 percent of the income distribution.

This article reviews these and other changes in the financial condition of U.S. families between 2001 and $2004 .^{?}$ The discussion draws on data from the Federal Reserve Board's Survey of Consumer Finances (SCF) for those years; it also uses evidence from earlier years of the survey to place the 2001-04 changes in a broader context.

\section{ECONOMIC BACKGROUND}

The U.S. economy was in a mild recession through much of 2001, and real gross domestic product was flat for the year. However, this pause in the growth of real GDP was followed by some pickup in 2002 and sharper gains of 4.1 percent in 2003 and 3.8 percent in 2004. The unemployment rate, which had peaked at 6.5 percent in mid-2003, fell to 5.1 percent in 2004. The rate of inflation, as measured by the consumer price index for all urban consumers (CPI), was moderate by historical standards over the 2001-04 period; for 2004 , it was 2.7 percent, nearly the same rate as for 2001 .

Developments in financial markets over the threeyear period were varied. The major stock market indexes declined before erasing most of the losses with an increase in 2004. Most interest rates had initially declined but began to rise by the end of 2004. For example, the interest rate on a thirty-year fixed-rate mortgage averaged 6.82 percent in September 2001, when about half the interviews for the 2001 SCF had been completed, and was 5.75 percent three years later. Lower interest rates also brought lower yields on liquid deposits, time deposits, and bonds; for example, the rate on a three-month certificate of deposit had dropped from an average of 3.69 percent for 2001 to slightly more than 1 percent in early 2004 , although the rate climbed to 2.45 percent by the end of the year.

1. See box "The Dala Ised in This Arlicle" lor a general description of the data. The appendix to this article protides a sunmary of key lechnical aspects of the survey. For a detailed discussion of the 1998 and 2001 surveys as well as relerences to earlier surveys, see Ina H. Aizcorbe. Arthur B. Kinnickell, and Kevin 13. Hoore (2003). "Recent Clhanges in L:S. lanily linanees: lividence from the 1998 and 2001 Survey of Consumer Finances," Federal Reverne Bulletin, vol. 89 (January), pp. 1-32.
The national house price index produced by the Office of Federal Housing Enterprise Oversight increased nearly 27 percent from 2001 to 2004 . Price increases varied sharply across the country; by area, the largest gains were in the New England, Middle Atlantic, and Pacific sections of the country-all more than 35 percent; average gains were considerably smaller in parts of the South. Homeownership rates continued a gradual climb.

Other institutional factors also affected family finances. Tax cuts enacted by the Jobs and Growth Tax Relief Reconciliation Act of 2003 increased the child tax credit, provided some concessions for married couples, and expanded the proportion of taxpayers covered by the lowest tax-rate bracket. A major element of the 2003 tax act was the decrease in tax rates on capital gains coupled with the change to taxing dividends at the same rate as capital gains. The proportion of families that use the Internet as a source for financial services, tools, or information continued to grow; according to the SCF, it rose from 32.5 percent in 2001 to 46.5 percent in 2004.

Several demographic shifts had important consequences for the structure of the population. The aging of the baby-boom population from 2001 to 2004 drove a 2 percentage point increase in the share of the population aged 55 to 64 . Overall population growth was about 3 percent, and, according to figures from the Bureau of the Census, 58 percent of the growth was due to net immigration. Also according to Census estimates, the number of households increased 3.6 percent - a rate slower than the 5.5 percent pace in the 1998-2001 period - and the average number of people per household remained close to two and a half.

\section{INCOME}

The change in real before tax family income between 2001 and 2004 stands in strong contrast to the change for the preceding three-year period ${ }^{2}$ Over the more

2. To measure income, the interviewers request information on the lamily"s cash income, before laxes, for the full calendar year preceding the surfyey. The components of income in the SCl are wages; self-enployment and business income; taxable and tax-exempt interest; divitends; realized capilal gains; lood stamps and other, related support prograins provided by gowerment; pensions and witlidrawals from retirenent accounts: Social Security: alimony and other support payments; and miscellaneous sources of income for all members of the primary economic unit in the household. 


\section{The Data Used in This Article}

Data from the Survey of Consumer Finances (SCF) are the basis of the analysis presented in this article. The SCF is a triennial interview survey of U.S. families sponsored by the Board of Governors of the Federal Reserve System with the cooperation of the U.S. Department of the Treasury. Since 1992, data for the SCF have been collected by NORC, a research organization at the University of Chicago, roughly between May and December of each survey year.

The majority of statistics included in this article are related to characteristics of "families." As used here, this term is more comparable to the U.S. Bureau of the Census definition of "households" than to its use of "families," which excludes the possibility of one-person families. The appendix provides full definitions of "family" for the SCF and the associated family "head." The survey collects information on families' total income before taxes for the calendar year preceding the survey. But the bulk of the data cover the status of families as of the time of the interview, including detailed information on their balance sheets and use of financial services as well as on their pensions, labor force participation, and demographic characteristics. Except in a small number of instances (see the appendix for details), the survey questionnaire has changed in only minor ways since 1989 , and every effort has been made to ensure the maximum degree of comparability of the data over time.

The need to measure financial characteristics imposes special requirements on the sample design for the survey. The SCF is expected to provide reliable information both on attributes that are broadly distributed in the population (such as homeownership) and on those that are highly concentrated in a relatively small part of the population (such as closely held businesses). To address this requirement, the SCF employs a sample design, essentially unchanged since 1989, consisting of two parts: a standard, geographically based random sample and a special oversample of relatively wealthy families. Weights are used to combine information from the two samples to make estimates for the full population. In the 2004 survey, 4,522 families were interviewed, and in the 2001 survey, 4,449 were interviewed.

This article draws principally upon the final data from the 2004 and 2001 surveys. To provide a larger context, some information is also included from the final versions of earlier surveys. ${ }^{1}$ Differences between estimates from earlier surveys as reported here and as reported in earlier Federal

1. Adtitional tabular intiormation from the survey is available at www.feteralreserve govipubs:oss:oss $2 / \operatorname{sct}^{2}(11)$ thome.html. These tables include diata compsirahle to the fiesures shewen in this article for all of the surveys from 1980 to 2101 . For some assets and telits by demographic

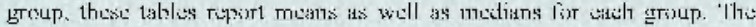
cstimates of the means, howewer, are more likely to be allected by simpliner error than are the estimates of the medians. The tables also include some

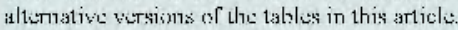

Reserve Bulletin articles are attributable to additional statistical processing, correction of minor data errors, revisions to the survey weights, conceptual changes in the definitions of variables used in the articles, and adjustments for inflation. In this article, all dollar amounts from the SCF are adjusted to 2004 dollars using the "current methods" version of the consumer price index (CPI) for all urban consumers. ${ }^{2}$

The principal detailed tables describing asset and debt holdings focus on the percent of various groups that have such items and the median holding for those that have them ${ }^{3}$ This conditional median is chosen to give a sense of the "typical" holding. Generally, when one deals with data that exhibit very large values for a relatively small part of the population as is the case for many of the items considered in this article-estimates of the median are often statistically less sensitive to such outliers than are estimates of the mean.

One liability of using the median as a descriptive device is that medians are not "additive"; that is, the sum of the medians of two items for a common population is not generally equal to the median of the sum (for example, median assets less median liabilities does not equal median net worth). In contrast, means for a common population are additive. Where a comparable median and mean are given, the growth of the mean relative to the median may usually be taken as indicative of change at the top of the distribution; for example, when the mean grows more rapidly than the median, it is typically taken to indicate that the values comprised by the top of the distribution rose more rapidly than those in the lower part of the distribution.

To provide a measure of the significance of the developments discussed in this article, standard errors due to sampling and imputation for missing data are given for selected estimates. Space limits prevent the inclusion of the standard errors for all estimates. Although we do not directly address the statistical significance of the results, the article highlights findings that are significant or are interesting in a broader context.

2. In an ongoing ettiort to improve accuracy, the Rureau of Labor Statistics has imtroduced several revisions to its (:I) methodislingy. 'The cumentmethits intex attempts to extend these changes to earlier years to oltain a

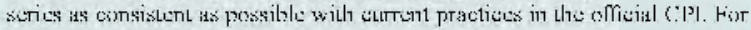

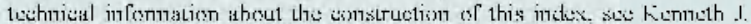
Stewalt and Stephen Is. Reed (1095) "Consumer F'rice Index Research

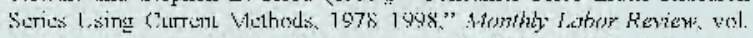
122 (June). pp. 20-38. To adjust assets and liabilities to 21$)(14$ dollars, the earlier survey data were multiplied by the following amounts: for 1095

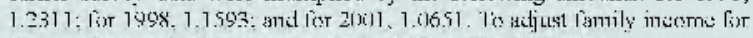
the previous salendar year to 2101)4 dollars, the following factors were applied: for $15095,1.2610$; for $1008,1.1757$; fior 20$)(11,1 .(15) 48$; ant fior 21$)(14$, $1.120 \%$

3. The median af a distribution is tetined as the value at which equal

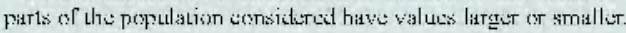


1. Before tax family income, percentage of families that saved, and distribution of families, by selected characteristics of: families, 1995-2004 surveys

Thousands of 2004 dollars except as noted

\begin{tabular}{|c|c|c|c|c|c|c|c|c|}
\hline \multirow{3}{*}{$\begin{array}{l}\text { Fannily } \\
\text { charachristic }\end{array}$} & \multicolumn{4}{|c|}{1555} & \multicolumn{4}{|c|}{1058} \\
\hline & \multicolumn{2}{|c|}{ Incime } & \multirow{2}{*}{$\begin{array}{c}\text { F'arcentage } \\
\text { inl' } \\
\text { tamilies } \\
\text { that saved }\end{array}$} & \multirow{2}{*}{$\begin{array}{l}\text { Purcentages } \\
\text { of } \\
\text { Pumilies }\end{array}$} & \multicolumn{2}{|c|}{ Income } & \multirow{2}{*}{$\begin{array}{c}\text { Percentage } \\
\text { ol } \\
\text { families } \\
\text { that saved }\end{array}$} & \multirow{2}{*}{$\begin{array}{l}\text { Percentage } \\
\text { of } \\
\text { limilies }\end{array}$} \\
\hline & Median & Mean & & & Metian & Mean & & \\
\hline All families $\ldots \ldots \ldots$ & $\begin{array}{r}37.8 \\
(.9)\end{array}$ & $\begin{array}{r}54.9 \\
(9)\end{array}$ & 55.2 & 100 & $\begin{array}{r}38.8 \\
(.9)\end{array}$ & $\begin{array}{l}61.7 \\
(1.3)\end{array}$ & 55.9 & 100 \\
\hline $\begin{array}{l}\text { Percemife of income } \\
\text { Less than } 2(1\end{array}$ & $\begin{array}{r}8.5 \\
21.7 \\
37.8 \\
56.1 \\
84.5 \\
138.6\end{array}$ & $\begin{array}{r}8.2 \\
21.6 \\
37.1 \\
57.0 \\
85.7 \\
215.8\end{array}$ & $\begin{array}{l}31.5 \\
43.4 \\
57.2 \\
65.8 \\
69.9 \\
84.2\end{array}$ & $\begin{array}{l}2(1 .(1) \\
2(1 .(1) \\
2 i) . i 1 \\
2(1 .(1) \\
1 i 1 . i) \\
1(1 .(1)\end{array}$ & $\begin{array}{r}9.6 \\
23.5 \\
38.8 \\
61.8 \\
91.6 \\
151.5\end{array}$ & $\begin{array}{r}9.2 \\
23.4 \\
34.4 \\
53.1 \\
92.2 \\
254.5\end{array}$ & $\begin{array}{l}32.1 \\
45.5 \\
56.1 \\
67.9 \\
73.7 \\
82.1\end{array}$ & $\begin{array}{l}210.1) \\
210.1) \\
20.10 \\
210.1) \\
10.10 \\
(10.1)\end{array}$ \\
\hline 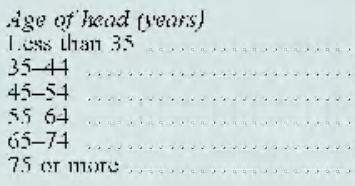 & $\begin{array}{l}31.5 \\
47.2 \\
40.5 \\
41.6 \\
33.7 \\
19.7\end{array}$ & $\begin{array}{l}35.4 \\
601.1 \\
81.4 \\
66.4 \\
40.1 \\
32.7\end{array}$ & $\begin{array}{l}56.4 \\
54.3 \\
58.1) \\
58.13 \\
511.1) \\
51.7\end{array}$ & $\begin{array}{r}24.5 \\
23.01 \\
17.5 \\
12.5 \\
12.1 \\
9.8\end{array}$ & $\begin{array}{l}31.8 \\
48.8 \\
58.8 \\
41.7 \\
28.2 \\
19.4\end{array}$ & $\begin{array}{l}41.9 \\
69.6 \\
80.9 \\
83.2 \\
54.2 \\
33.9\end{array}$ & $\begin{array}{l}53.11 \\
57.3 \\
57.8 \\
61.1 \\
56.3 \\
48.6\end{array}$ & $\begin{array}{l}23.3 \\
23.3 \\
10.2 \\
12.8 \\
11.2 \\
10.2\end{array}$ \\
\hline 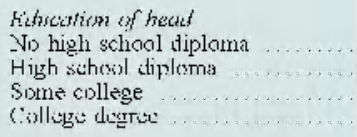 & $\begin{array}{l}17.0 \\
32.1 \\
37.8 \\
56.3\end{array}$ & $\begin{array}{l}25.8 \\
43.11 \\
45.5 \\
87.9\end{array}$ & $\begin{array}{l}42.8 \\
50.6 \\
54.1 \\
68.2\end{array}$ & $\begin{array}{l}18.5 \\
31.7 \\
19 .(1 \\
311.7\end{array}$ & $\begin{array}{l}18.0 \\
33.4 \\
41.1 \\
63.7\end{array}$ & $\begin{array}{l}25.2 \\
42.9 \\
58.9 \\
943\end{array}$ & $\begin{array}{l}35.5 \\
53.7 \\
56.7 \\
65.6\end{array}$ & $\begin{array}{l}16.5 \\
31.9 \\
18.5 \\
33.2\end{array}$ \\
\hline $\begin{array}{l}\text { Race of ethnicity of resporderst } \\
\text { White nism-Hispinic } \\
\text { Nonwhite or Ilispanis }\end{array}$ & $\begin{array}{l}40.7 \\
24.4\end{array}$ & $\begin{array}{l}601.4 \\
36 .(1\end{array}$ & $\begin{array}{l}59.1 \\
41.7\end{array}$ & $\begin{array}{l}77.6 \\
22.4\end{array}$ & $\begin{array}{l}4.2 \\
27.1\end{array}$ & $\begin{array}{l}68.7 \\
38.5\end{array}$ & $\begin{array}{l}\text { Sil.i1 } \\
42.3\end{array}$ & $\begin{array}{l}76.8 \\
23.2\end{array}$ \\
\hline 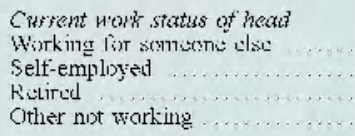 & $\begin{array}{l}4.5 .4 \\
45.7 \\
20.7 \\
1.5 .0\end{array}$ & $\begin{array}{l}50.6 \\
58.5 \\
34.5 \\
22.2\end{array}$ & $\begin{array}{l}60.4 \\
63.4 \\
4(6.10 \\
310.8\end{array}$ & $\begin{aligned} 58.3 \\
1(1.3 \\
25.1 \\
6.4\end{aligned}$ & $\begin{array}{l}47.11 \\
61.1 \\
22.3 \\
13.5\end{array}$ & $\begin{array}{r}62.1 \\
126.8 \\
33.2 \\
25.2\end{array}$ & $\begin{array}{l}50.8 \\
61.1 \\
48.7 \\
33.3\end{array}$ & $\begin{array}{r}59.2 \\
11.3 \\
24.4 \\
5.1\end{array}$ \\
\hline 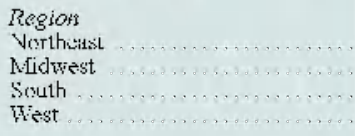 & $\begin{array}{l}37.8 \\
38.6 \\
3.5 .11 \\
30.1\end{array}$ & $\begin{array}{l}5 i 1.6 \\
56 .(1 \\
5 i 1.9 \\
55.2\end{array}$ & $\begin{array}{l}52.6 \\
50.2 \\
54.6 \\
54.1\end{array}$ & $\begin{array}{l}19.8 \\
23.5 \\
35.1 \\
21.2\end{array}$ & $\begin{array}{l}41.1 \\
38.2 \\
36.6 \\
42.0\end{array}$ & $\begin{array}{l}70.7 \\
56.8 \\
57.3 \\
60.2\end{array}$ & $\begin{array}{l}53.5 \\
58.3 \\
55.11 \\
56.9\end{array}$ & $\begin{array}{l}19.3 \\
23.5 \\
3.5 .7 \\
21.5\end{array}$ \\
\hline $\begin{array}{l}\text { Horsing status } \\
\text { Ownit } \ldots \ldots \ldots \ldots \ldots \ldots \ldots \ldots \ldots \ldots \ldots \\
\text { Renter or other }\end{array}$ & $\begin{array}{l}46.7 \\
22.7\end{array}$ & $\begin{array}{l}6 \$ . i 1 \\
3(1.9)\end{array}$ & $\begin{array}{l}61.3 \\
44.1)\end{array}$ & $\begin{array}{l}64.7 \\
35.3\end{array}$ & $\begin{array}{l}50.7 \\
23.5\end{array}$ & $\begin{array}{l}77.3 \\
31.0\end{array}$ & $\begin{array}{l}62.2 \\
43.4\end{array}$ & $\begin{array}{l}66.2 \\
3.8 .8\end{array}$ \\
\hline 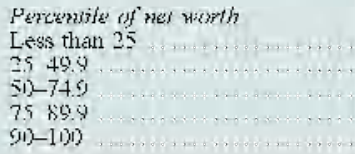 & $\begin{array}{l}17.8 \\
3.5 .3 \\
43.5 \\
52.6 \\
00.1\end{array}$ & $\begin{array}{r}22.5 \\
38.6 \\
5(1.1 \\
65.11 \\
172.8\end{array}$ & $\begin{array}{l}35.7 \\
51.4 \\
50.4 \\
68.8 \\
83.4\end{array}$ & $\begin{array}{l}25.1 \\
25.11 \\
25.01 \\
15.11 \\
10.0\end{array}$ & $\begin{array}{r}18.5 \\
35.3 \\
470 \\
65.8 \\
102.4\end{array}$ & $\begin{array}{r}236 \\
39.3 \\
54.3 \\
78.4 \\
306.3\end{array}$ & $\begin{array}{l}36,3 \\
\text { Sil. } 3 \\
\text { 6il.8 } \\
71 \text { y } \\
80.0\end{array}$ & $\begin{array}{l}25.11 \\
25.10 \\
25.10 \\
1.5 .10 \\
10.1)\end{array}$ \\
\hline
\end{tabular}

NotE: For questions on income, respondents were asked to base their answers on the calendar year preceding the interview. For questions on saving, respondents were asked to base their answers on the twelve months preceding the interview. For discussion of racial and ethnic designations, see the appendix.

Percentage distributions may not sum to 100 because of rounding. Dollars have been converted to 2004 values with the current-methods consumer price

recent period, median income rose 1.6 percent, while the mean fell 2.3 percent (table 1 ). ${ }^{3}$ Over the preced-

3. Over the 2001-04 period, estimates of inllation-adjusted household incone for the previous year from the Current Population Survey (CPS) of the Bureau of the Census show a decline in both the median (1.5 percent) and the mean (2.6 pereent). Typically, the SCF shows a higher level of mean income than does the CTS; for 2004, the SCF yiclds an estimate of $\$ 70,700$, while the CPS yields an estinate of $\$ 62.200$. This differenee in mean levels is largely the result of the trumcation of large values in the CTS tata above a certain amount. which is done with the intent of mimimizing the possibility that

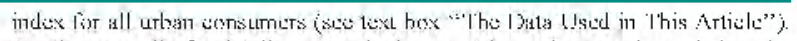

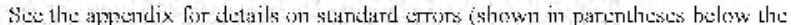
tirst row of data firr the means ant medians here ant in table $3 j$ and fior detiniLims of Panily and family hasid.

ing three-year period, the median had increased 9.5 percent, and the mean had increased 17.3 percent.

respondents in that survey might be identifiable. As discussed in more detail in the appendix. the two surveys also difter in their definitions of the units of observation and in other aspects of their methodologies. The national income and product accounts (NIPA) provide aggregate information on the incoines of houscholds. If VIPA estinates of personal incone are adjusted for inflation and growtle in the number of households over the 2001-04 period, they imply virtually no change in household income. 
1.-Continued

Thousands of 2004 dollars except as noted

\begin{tabular}{|c|c|c|c|c|c|c|c|c|}
\hline \multirow{3}{*}{$\begin{array}{l}\text { Family } \\
\text { characturistic }\end{array}$} & \multicolumn{4}{|c|}{20101} & \multicolumn{4}{|c|}{$21)(14$} \\
\hline & \multicolumn{2}{|c|}{ Income } & \multirow{2}{*}{$\begin{array}{c}\text { F'ercentage } \\
\text { oil' } \\
\text { tamilies } \\
\text { that saved }\end{array}$} & \multirow{2}{*}{$\begin{array}{c}\text { Percentage } \\
\text { of } \\
\text { Pitmilies }\end{array}$} & \multicolumn{2}{|c|}{ Ineome } & \multirow{2}{*}{$\begin{array}{c}\text { Percentage } \\
\text { si } \\
\text { families } \\
\text { that savest }\end{array}$} & \multirow{2}{*}{$\begin{array}{l}\text { Percentage } \\
\text { of } \\
\text { lismilies }\end{array}$} \\
\hline & Median & Mèan & & & Metian & Mean & & \\
\hline All families $\ldots . \ldots \ldots$. & $\begin{array}{r}+2.5 \\
(.8)\end{array}$ & ?2.4 & 59.2 & 100 & $\begin{array}{l}43.2 \\
(.8)\end{array}$ & $\begin{array}{l}70.7 \\
(1.2)\end{array}$ & 56.1 & 100 \\
\hline 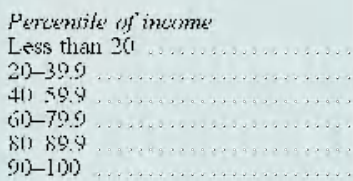 & $\begin{array}{r}119.0 \\
35.15 \\
42.5 \\
619.1) \\
1135.1 \\
1810.5\end{array}$ & $\begin{array}{r}10.7 \\
25.7 \\
42.9 \\
65.4 \\
1114.4 \\
322.4\end{array}$ & $\begin{array}{l}31.1) \\
53.4 \\
61.3 \\
72.1 \\
74.9 \\
84.3\end{array}$ & $\begin{array}{l}2(1.11 \\
2(1.11 \\
2 i 1 . i) \\
2(1.11 \\
7 i, i) \\
1(1.11\end{array}$ & $\begin{array}{r}11.1 \\
25.7 \\
43.2 \\
68.1 \\
111.7 \\
184.8\end{array}$ & $\begin{array}{r}10.8 \\
30.1 \\
43.4 \\
65.1 \\
106.5 \\
3102.1\end{array}$ & $\begin{array}{l}34.01 \\
43.5 \\
54.4 \\
65.3 \\
77.5 \\
8(1.6\end{array}$ & $\begin{array}{l}2(1) .1) \\
210.1) \\
2(0.0 \\
210.10 \\
10.10 \\
11.1)\end{array}$ \\
\hline 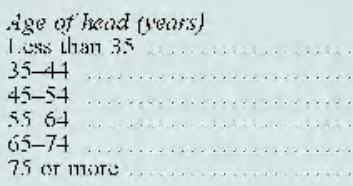 & $\begin{array}{l}35.6 \\
54.7 \\
58.1 \\
48.2 \\
20.6 \\
23.8\end{array}$ & $\begin{array}{l}47.1 \\
82.1 \\
55.3 \\
92.6 \\
61.5 \\
39.1\end{array}$ & $\begin{array}{l}52.9 \\
63.3 \\
61.7 \\
62.0 \\
61.8 \\
55.5\end{array}$ & $\begin{array}{l}22.7 \\
22.3 \\
20.6 \\
13.2 \\
101.7 \\
11.4\end{array}$ & $\begin{array}{l}32.9 \\
49.8 \\
61.1 \\
54.4 \\
33.3 \\
23.7\end{array}$ & $\begin{array}{r}45.1 \\
73.8 \\
04.4 \\
101.3 \\
59.6 \\
40.4\end{array}$ & $\begin{array}{l}55.11 \\
58.1 \\
58.5 \\
58.5 \\
57.1 \\
45.7\end{array}$ & $\begin{array}{l}22.2 \\
219.6 \\
21.8 \\
1.5 .2 \\
11.5 \\
10.7\end{array}$ \\
\hline 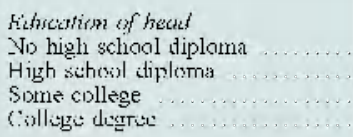 & $\begin{array}{l}18.1 \\
36.1 \\
43.6 \\
72.3\end{array}$ & $\begin{array}{r}26.7 \\
47.7 \\
59.1 \\
124.2\end{array}$ & $\begin{array}{l}38.7 \\
56.7 \\
61.7 \\
70.13\end{array}$ & $\begin{array}{l}16.01 \\
31.7 \\
18.3 \\
34.1\end{array}$ & $\begin{array}{l}12.4 \\
3.5 .6 \\
41.1 \\
73.13\end{array}$ & $\begin{array}{r}25.9 \\
448 \\
56.8 \\
117.5\end{array}$ & $\begin{array}{l}35.5 \\
54.11 \\
51.1 \\
65.3\end{array}$ & $\begin{array}{l}14.4 \\
30.6 \\
18.4 \\
366\end{array}$ \\
\hline $\begin{array}{l}\text { Race or ethniciti of resporsdent } \\
\text { White nisn-Hispinic } \\
\text { Nonwhite or Ilispanic }\end{array}$ & $\begin{array}{l}48.2 \\
27.4\end{array}$ & $\begin{array}{l}\$ 1.9 \\
43.3\end{array}$ & $\begin{array}{l}6.3 .1 \\
47.4\end{array}$ & $\begin{array}{l}75.4 \\
246\end{array}$ & $\begin{array}{l}49.4 \\
29.8\end{array}$ & $\begin{array}{l}8 i 1.7 \\
44.5\end{array}$ & $\begin{array}{l}6 i 1.1 \\
45.6\end{array}$ & $\begin{array}{l}72.2 \\
27.8\end{array}$ \\
\hline 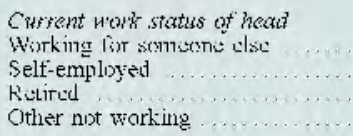 & $\begin{array}{l}50.4 \\
67.4 \\
22.4 \\
17.6\end{array}$ & $\begin{array}{r}71.7 \\
147.3 \\
42.6 \\
38.8\end{array}$ & $\begin{array}{l}61.6 \\
71) .4 \\
50.6 \\
42.3\end{array}$ & $\begin{array}{r}6 i 1.9 \\
11.7 \\
22.9 \\
4.5\end{array}$ & $\begin{array}{l}49.3 \\
615.7 \\
24.4 \\
215.5\end{array}$ & $\begin{array}{r}7 i 1.1 \\
141.5 \\
43.2 \\
37.4\end{array}$ & $\begin{array}{l}50.2 \\
68.7 \\
44.11 \\
44.5\end{array}$ & $\begin{array}{r}60.1 \\
11.8 \\
23.7 \\
4.4\end{array}$ \\
\hline 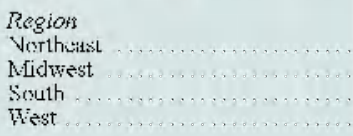 & $\begin{array}{l}4.0 \\
45.7 \\
38.3 \\
43.4\end{array}$ & $\begin{array}{l}82.7 \\
68.9 \\
65.4 \\
78.5\end{array}$ & $\begin{array}{l}58.1 \\
(0.1) \\
57.3 \\
51.5\end{array}$ & $\begin{array}{l}19.1 \\
23.1 \\
36.2 \\
21.8\end{array}$ & $\begin{array}{l}50.9 \\
45.2 \\
37.11 \\
45.2\end{array}$ & $\begin{array}{l}87.5 \\
67.4 \\
61.9 \\
74.5\end{array}$ & $\begin{array}{l}50.5 \\
56.9 \\
52.5 \\
55.2\end{array}$ & $\begin{array}{l}18.8 \\
22.0 \\
36.3 \\
22.1\end{array}$ \\
\hline $\begin{array}{l}\text { Horsing status } \\
\text { Ownet . } \\
\text { Renter of other }\end{array}$ & $\begin{array}{l}55.5 \\
26.3\end{array}$ & $\begin{array}{l}911.6 \\
34.3\end{array}$ & $\begin{array}{l}66.7 \\
43.65\end{array}$ & $\begin{array}{l}67.7 \\
32.3\end{array}$ & $\begin{array}{l}55.2 \\
24.6\end{array}$ & $\begin{array}{l}87.3 \\
33.7\end{array}$ & $\begin{array}{l}62.3 \\
42.3\end{array}$ & $\begin{array}{l}69.1 \\
319.9\end{array}$ \\
\hline 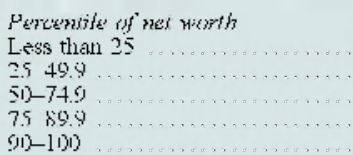 & $\begin{array}{r}21.1) \\
37.2 \\
54.2 \\
74.6 \\
136.9\end{array}$ & $\begin{array}{r}25.5 \\
42.3 \\
62.2 \\
83.9 \\
273.1\end{array}$ & $\begin{array}{l}34.5 \\
54.3 \\
68.1) \\
77.7 \\
83.0\end{array}$ & $\begin{array}{l}25.01 \\
25 . i 1 \\
25.01 \\
15.11 \\
10.11\end{array}$ & $\begin{array}{r}21.5 \\
37 . i 1 \\
53.4 \\
77.01 \\
14.8\end{array}$ & $\begin{array}{r}25.1 \\
42.2 \\
601.6 \\
87.8 \\
256.01\end{array}$ & $\begin{array}{l}34.8 \\
53.6 \\
62.2 \\
72.4 \\
76.1\end{array}$ & $\begin{array}{l}25.1) \\
2.5 .0 \\
25.11 \\
1.5 .1 \\
10.1)\end{array}$ \\
\hline
\end{tabular}

The change over the 2001-04 period was strongly influenced by a 6.2 percent decline in the overall median amount of wages measured in the survey and a 3.6 percent decline in the mean (data not shown in the tables); wages represent the largest share of family income. Investment-related incomes also declined.

Some patterns of income distribution hold generally across the years of SCF data shown in table 1 . Across age classes, median and mean incomes show a life-cycle pattern, rising to a peak in the middle age groups and then declining for groups that are older and increasingly more likely to be retired. Income also shows a strong positive association with education; in particular, incomes for families headed by persons who have a college degree are substantially higher than for those with any lesser amount of schooling. Incomes of white non-Hispanic families are substantially higher than those of other families. ${ }^{4}$ Families headed by self-employed workers consistently have the highest median and mean incomes of all work-status groups. Income is also higher for homeowners than for other families, and it is progressively higher for groups with greater net worth. Across the four regions of the country as defined by the Bureau of the Census, the ordering of median

4. See the appendix for a discussion of racial and ethnic identificalion in the SCF. 
incomes over time has varied, but the means generally show higher values for the Northeast and the West than for the Midwest and the South.

\section{Income by Demographic Category}

Across the lowest 90 percent of the income distribution between 2001 and 2004, changes in median and mean incomes varied in direction, but all the changes were 2 percent or less in absolute value. ${ }^{5}$ For the top 10 percent, changes in the median and mean were more substantial, but changes in the two statistics were in opposite directions; the median rose 2.3 percent, while the mean fell 6.3 percent. The decline in the mean for this group appears to be a result of a decline since 2001 in investment income, which tends to be concentrated among high-income families. The changes throughout the income distribution contrast with the broad and substantial gains in both median and mean incomes that had been seen over the preceding three-year period, when both measures had risen 10 percent or more for most groups.

The income changes across almost all age groups were substantial. For the groups under age 45, both median and mean incomes dropped. For the remaining age groups, median incomes rose strongly except for the 75-or-older group, but the means rose only for the 55-64 group and the 75-or-older group. Over the preceding three-year period, median income had increased for most age groups, particularly for the oldest, while the mean rose for all groups but especially for the 45-54 group.

Across education groups, median incomes rose only for families headed by persons with less than a high school diploma and for families headed by persons with a college degree; growth was particularly strong for the former group-7.2 percent-but that group still has the lowest median income of all education groups. ${ }^{6}$ Mean incomes declined for all educa-

5. Ilere are selected pereentiles of the incone distribution for the past four surweys, in 2004 dollans:

\begin{tabular}{|c|c|c|c|c|}
\hline $\begin{array}{l}\text { Percentile } \\
\text { of incisme }\end{array}$ & 1495 & 1998 & 200101 & $20)(14$ \\
\hline 201. & 15,1001 & 16,1001 & $17, \sin 01$ & $18, .91010$ \\
\hline 4i). & $28,1(00)$ & $30,600 \mathrm{i}$ & 328000 & 33,900 \\
\hline$\ldots \ldots \ldots \ldots \ldots \ldots \ldots$ & $45,61)(1$ & $40,-40)(1$ & $54,71)(1$ & $53,(01) 0$ \\
\hline$x_{i j}$. & $73.8(0 i)$ & $79.10 i)$ & $87.60 i)$ & 89,300 \\
\hline$Q(1$. & $1(11,1)(1$ & $1(18,2)(1$ & $126,(1)(1$ & 129,4100 \\
\hline
\end{tabular}

6. Over the 2001 (44 period, the share of families with a head with less than a high selool diploma declined 1.6 pereentage points, to 14.4 peresent. Compared with 2001. a larger sliare of the 2004 group was nonwhile or Hispanic, and the share younger than 45 increased slightly (data not shown in the tables). tion groups. In the preceding three-year period, mean incomes had increased markedly for all education groups except the some-college group, and median incomes had increased notably for all groups except the no-high-school-diploma group; the median had increased most strongly for the college-degree group.

In the 2001-04 period, the median income of nonwhite or Hispanic families rose 8.8 percent, and the mean rose 3.7 percent. In contrast, the median for white non-Hispanic families rose 2.5 percent, and the mean declined 1.5 percent. However, both the median and the mean for nonwhites or Hispanics were about 60 percent of the corresponding figures for nonHispanic whites in 2004. Between 1998 and 2001, the median income of nonwhite or Hispanic families had been about unchanged, while the median had increased 9.0 percent for other families; the mean had risen for both groups. ${ }^{7}$

Of the work-status groups, only the retired group had an increase in both median and mean incomes between 2001 and 2004; the median rose 8.9 percent and the mean 1.4 percent $^{8}$ For the other-not-working group, the median rose 16.5 percent, and the mean declined 3.6 percent; since before the 1995 survey, this group has had the lowest measures of income of any of the work-status groups. For the other workstatus groups, both median and mean incomes fell from 2001 to 2004. Over the 1998-2001 period, median income had increased most for the selfemployed and the other-not-working groups; mean incomes were higher for all groups, especially the other-not-working group.

By region, the only growth in both median and mean incomes between 2001 and 2004 was in the Northeast. In the West, only the median rose, and in the Midwest and South, median and mean incomes both fell. Over the 1998-2001 period, regional median income increased at the highest rate in the Midwest; growth in the mean was similar for all regions except the South, where it was somewhat lower.

7. If the information on Hispanic or $\mathrm{T}$ atino ethnic identification is used in the classification of the 2004 results, the median incone of nomphites or Ilispanics was $\$ 30.000$. and the mean was $\$ 45.400$ : for other lamilies, the median was $\$ 49,900$, and the mean was $\$ 81,200$. These figures difter only slightly from those given in table 1 .

8. 10 be included in the retired group. the fanily head inust report being retired and not currently working al any job or report being oul of the labor foree and over the age of 65 . The olher-not-working group comprises fanily heads who are uncmployed and those who are out of the labor lorce but who are neither relired nor over age 65 ; the composition of this group shilied from 2001 to 2004 to include more families with a head who had a college degree. In 2004, 62.1 pereent of the group was unenployed. and the remainder was out of the labor force; in 2001, 52.5 percent of the group was unemployed (data not shown in the tables). 
By housing status, median and mean incomes fell both for homeowners and for other families from 2001 to 2004 . The decline in the median for homeowners was only 0.5 percent, but the decline for other families was 6.5 percent. The fact that the median for these groups dropped while the overall median showed a gain may be explained, in part, by an influx of new homeowners, who tend, on the one hand, to have incomes lower than those of previously existing homeowners and, on the other hand, to have incomes higher than those of remaining renters. Over the preceding three-year period, median and mean incomes had risen both for homeowners and for others.

By percentile of net worth, median income increased from 2001 to 2004 only for families above the 75 th percentile of the wealth distribution; it fell or was little changed for other groups. ${ }^{9}$ Mean income rose only between the 75th and 90th percentiles of the wealth distribution. From 1998 to 2001, the two income measures had increased for all groups but particularly for the top decile.

\section{Saving}

Because saving out of current income is an important determinant of family net worth, the SCF asks respondents whether, over the preceding year, the family's spending was less than, more than, or about equal to its income. Though only qualitative, the answers are a useful indicator of whether families are saving. 'Asking instead for a specific dollar amount would require much more time from respondents and would likely lower the rate of response to the survey.

Overall, from 2001 to 2004 the proportion of families that reported that they had saved in the preceding year fell 3.1 percentage points, to 56.1 percent, although the proportion remained higher than in the 1995 and 1998 surveys. 'Across most of the demographic groups over the recent three-year period, the predominant pattern is also one of a decline in the proportion of families that saved. In contrast, the 2001 survey had predominantly shown increases from 1998 .

9. Ilere are sclested percentiles of the distribution of net worth for the past four surveys. in 2004 dollars:

\begin{tabular}{|c|c|c|c|c|}
\hline $\begin{array}{l}\text { Percentile } \\
\text { of net worth }\end{array}$ & 1995 & 1998 & $2 i)(01$ & $2 i)(1,4$ \\
\hline $\begin{array}{l}25 \\
\begin{array}{l}25 \\
s_{i j}\end{array} \\
75\end{array} \ldots \ldots \ldots$ & $\begin{array}{r}12,30(1 \\
70,80 i) \\
197,80(1 \\
469,0(0 i)\end{array}$ & $\begin{array}{r}11,51)(1 \\
83,10 i) \\
242,10(1 \\
572,10 i)\end{array}$ & $\begin{array}{r}13,51)(1 \\
91,70 i) \\
3(11,10(1) \\
780,90 i)\end{array}$ & $\begin{array}{r}13,3100 \\
93,100 \\
328,500 \\
831,600\end{array}$ \\
\hline
\end{tabular}

2. Reasons respondents gave as most important for their families' saving, distributed by type of reason, 1995-2004 surveys

Percent

\begin{tabular}{|c|c|c|c|c|}
\hline Reason & 1505 & 15,98 & $2(11) 1$ & $2(11) 4$ \\
\hline Fiduciationn ..... & 10.8 & 11.0 & 10.9 & 11.6 \\
\hline For the family ... & 2.7 & 4.1 & 5.1 & 4.7 \\
\hline Buying own home & 5.1 & 4.4 & 4.2 & $5.1)$ \\
\hline I'urethases ......... & 12.8 & 9.7 & 9.5 & 7.7 \\
\hline Retirement & 23.7 & $33.1)$ & 32.1 & 34.7 \\
\hline I.iquidily. & 33.10 & 29.8 & 31.2 & 30,0 \\
\hline Investments .......... & 4.2 & $2.1)$ & $1.1)$ & 1.5 \\
\hline Vo pirticular teison .... & 8 & 1.3 & 1.1 & .7 \\
\hline $\begin{array}{l}\text { When asked for a reason, } \\
\text { repertud dos nith sive } \\
\text { Total }\end{array}$ & 1(11) & $\begin{array}{c}4.9 \\
1010\end{array}$ & $\begin{array}{l}4.9 \\
1010\end{array}$ & ${ }_{1(1) 1}^{4.11}$ \\
\hline
\end{tabular}

Note: See note to table 1 and text note 10 .

In contrast to the SCF measure, estimates of the personal saving rate from the national income and product accounts (NIPA) show no change on an annual basis from 2001 to 2004 . However, the SCF and NIPA concepts of saving differ in some important ways. First, the underlying SCF question asks only whether the family's spending has been less than, more than, or about the same as its income over the past year. Thus, fewer families may be saving, but those that are doing so may be saving more. Second, the NIPA measure of saving relies on definitions of income and consumption that may not be the same as those that respondents had in mind when answering the survey questions. For example, the NIPA measure of personal income includes payments employers make to their employees' defined-benefit pension plans but not the payments made from such plans to families, whereas the SCF measure includes only the latter. The SCF measure also includes realized capital gains, whereas the NIPA measure excludes capital gains of all forms, realized and unrealized.

'A separate question in the survey asks about families' more typical saving habits. In 2004, 7.0 percent of families reported that their spending usually exceeds their income; 16.1 percent reported that the two are usually about the same; 36.1 percent reported that they typically save income "left over" at the end of the year, income of one family member, or unusual additional income; and 40.8 percent reported that they save regularly (data not shown in the tables). These figures are not much changed over the last three surveys.

The SCF also collects information on families' most important motivations for saving (table 2). ${ }^{10}$

10. Although families were asked to report their motives for saving regardless of whether they were eurrently sawing. some families reported only that they do not save. The analysis here is confined to the first reason reporled by lamilies. 
3. Family net worth, by selected characteristics of families, 1995-2004 surveys

Thousands of 2004 dollars

\begin{tabular}{|c|c|c|c|c|c|c|c|c|}
\hline \multirow{2}{*}{$\begin{array}{l}\text { Family } \\
\text { characturistic }\end{array}$} & \multicolumn{2}{|c|}{1995} & \multicolumn{2}{|c|}{$159 x$} & \multicolumn{2}{|c|}{$2 i(1) 1$} & \multicolumn{2}{|c|}{20114} \\
\hline & Vucitian & Mثill & Muctian & Me:an & Modian & Me:a17 & Mectian & Vu:an \\
\hline All liamilies ........ & $\begin{array}{l}70.8 \\
(2.4)\end{array}$ & $\begin{array}{r}260.8 \\
(65.4)\end{array}$ & $\begin{array}{l}\mathbf{8 3 . 1} \\
(3.2)\end{array}$ & $\begin{array}{l}327.5 \\
(11) .7)\end{array}$ & $\begin{array}{l}91.7 \\
(3.3)\end{array}$ & $\begin{aligned} 421.5 \\
(7.1)\end{aligned}$ & $\begin{array}{l}93.1 \\
(4.3)\end{array}$ & $\begin{array}{r}48.2 \\
(9.7)\end{array}$ \\
\hline 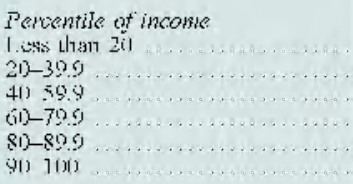 & $\begin{array}{r}7.4 \\
41.3 \\
57.1 \\
93.6 \\
157.7 \\
436.9\end{array}$ & $\begin{array}{r}54.7 \\
97.4 \\
126.13 \\
108.5 \\
316.8 \\
1.338 .0\end{array}$ & $\begin{array}{r}6.8 \\
38.4 \\
61.9 \\
130.2 \\
218.5 \\
524.4\end{array}$ & $\begin{array}{r}5.5 \\
111.5 \\
146.6 \\
238.3 \\
377.1 \\
1.793 .9\end{array}$ & $\begin{array}{r}\$ .4 \\
35.5 \\
66.5 \\
15(1.7 \\
280.3 \\
\$ 87.9\end{array}$ & $\begin{array}{r}56.1 \\
121.8 \\
171.4 \\
311.3 \\
4865 \\
24.6 \\
416.7\end{array}$ & $\begin{array}{r}7.5 \\
34.3 \\
71.6 \\
161.01 \\
311.1 \\
924.1\end{array}$ & $\begin{array}{r}72.6 \\
122.1) \\
193.8 \\
342.8 \\
485.1 \\
2.534 .4\end{array}$ \\
\hline 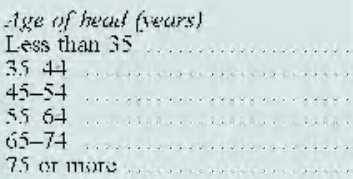 & $\begin{array}{r}14.8 \\
64.2 \\
115.8 \\
141.9 \\
136.5 \\
114.5\end{array}$ & $\begin{array}{l}53.2 \\
176.8 \\
364.8 \\
471.1 \\
420.3 \\
317.9\end{array}$ & $\begin{array}{l}10.6 \\
73.5 \\
122.3 \\
148.2 \\
165.8 \\
14.6\end{array}$ & $\begin{array}{r}74.1 \\
227.6 \\
42(1.2 \\
617 . i 1 \\
541.1 \\
36 i 1.3\end{array}$ & $\begin{array}{r}12.3 \\
83.6 \\
141.5 \\
193.3 \\
187.8 \\
161.2\end{array}$ & $\begin{array}{r}56.6 \\
276.4 \\
517.5 \\
775.4 \\
717.0 \\
496.2\end{array}$ & $\begin{array}{r}14.2 \\
64.4 \\
144.7 \\
248.7 \\
19(1.1 \\
163.1\end{array}$ & $\begin{array}{r}73.5 \\
299.2 \\
542.7 \\
543.8 \\
6911.9 \\
528.1\end{array}$ \\
\hline 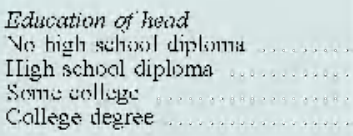 & $\begin{array}{r}27.9 \\
53.9 \\
57.6 \\
128.6\end{array}$ & $\begin{array}{l}1103.7 \\
163.7 \\
232.3 \\
473.7\end{array}$ & $\begin{array}{r}24.5 \\
62.7 \\
\$ 5.6 \\
165.7\end{array}$ & $\begin{array}{r}91.4 \\
182.9 \\
275.5 \\
612.3\end{array}$ & $\begin{array}{r}27.2 \\
61.8 \\
76.3 \\
227.2\end{array}$ & $\begin{array}{l}119.7 \\
192.5 \\
3 i 13.8 \\
845.7\end{array}$ & $\begin{array}{r}201.6 \\
68.7 \\
60.3 \\
226.1\end{array}$ & $\begin{array}{l}136.5 \\
156.8 \\
3 i 18.6 \\
851.3\end{array}$ \\
\hline $\begin{array}{l}\text { Race of ethnicity of respossdent } \\
\text { White nisn-Hispinic } \\
\text { Nonwhite or IIispanis }\end{array}$ & $\begin{array}{l}94.3 \\
10.5\end{array}$ & $\begin{array}{r}308.7 \\
0.12\end{array}$ & $\begin{array}{r}111 . i 1 \\
19.3\end{array}$ & $\begin{array}{l}3 \% 1.1 \\
116.5\end{array}$ & $\begin{array}{r}129.6 \\
19.1\end{array}$ & $\begin{array}{l}578.7 \\
123.8\end{array}$ & $\begin{array}{r}14 i 1.7 \\
24.8\end{array}$ & $\begin{array}{l}561.8 \\
153.1\end{array}$ \\
\hline 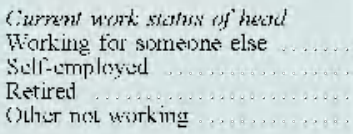 & $\begin{array}{r}51) .3 \\
191.8 \\
000.0 \\
4.5\end{array}$ & $\begin{array}{r}168.4 \\
862.8 \\
277.2 \\
70.1\end{array}$ & $\begin{array}{r}61.2 \\
28 \% . i \\
131 .(1 \\
4.1\end{array}$ & $\begin{array}{r}154.8 \\
1.1071 .3 \\
356.5 \\
85.8\end{array}$ & $\begin{array}{r}55.3 \\
375.2 \\
120.4 \\
4.5\end{array}$ & $\begin{array}{r}2419.1 \\
1.3410 .6 \\
479.2 \\
191.7\end{array}$ & $\begin{array}{r}67.2 \\
335.6 \\
139.8 \\
11.8\end{array}$ & $\begin{array}{r}268.5 \\
1.423 .2 \\
4(19.1) \\
162.3\end{array}$ \\
\hline $\begin{array}{l}\text { Rexpiom } \\
\text { Violtheast } \\
\text { Midwest } \\
\text { Sisuth } \\
\text { Wust . . . . }\end{array}$ & $\begin{array}{r}102.1) \\
817.8 \\
54.2 \\
67.4\end{array}$ & $\begin{array}{l}3108.0 \\
241.7 \\
220.5 \\
286.1\end{array}$ & $\begin{array}{l}109.3 \\
53.1 \\
71.0 \\
71.1\end{array}$ & $\begin{array}{l}351.3 \\
288.5 \\
3(15) .6 \\
379.1\end{array}$ & $\begin{array}{r}08.3 \\
111.3 \\
78.6 \\
93.3\end{array}$ & $\begin{array}{l}481) .1) \\
3(61.6 \\
4(11) .4 \\
468.8\end{array}$ & $\begin{array}{r}151.7 \\
115.8 \\
63.8 \\
94.8\end{array}$ & $\begin{array}{l}560.1 \\
436.1 \\
348.1 \\
523.7\end{array}$ \\
\hline 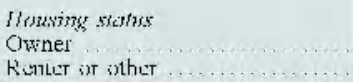 & $\begin{array}{r}128.1 \\
6.0\end{array}$ & $\begin{array}{r}373.7 \\
53.8\end{array}$ & $\begin{array}{r}153.2 \\
4.9\end{array}$ & $\begin{array}{r}46 i 8.7 \\
5 i 1.4\end{array}$ & $\begin{array}{r}182.0 \\
5.1\end{array}$ & $\begin{aligned} 564.8 \\
5 \times .5\end{aligned}$ & $\begin{array}{r}184.4 \\
4 . i 1\end{array}$ & $\begin{array}{r}624.0 \\
54.1\end{array}$ \\
\hline 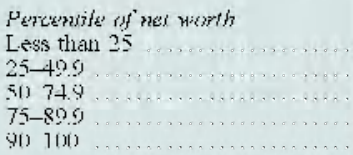 & $\begin{array}{r}1.2 \\
34.7 \\
117.1 \\
272.3 \\
836.7\end{array}$ & $\begin{array}{r}-.2 \\
37.65 \\
122.6 \\
293.6 \\
1.766 .7\end{array}$ & $\begin{array}{r}.6 \\
37.9 \\
139.7 \\
357.7 \\
1.1030 .1\end{array}$ & $\begin{array}{r}-2.1 \\
41.6 \\
149.1 \\
372.6 \\
2.241 .2\end{array}$ & $\begin{array}{r}1.2 \\
43.4 \\
166.8 \\
458.2 \\
1.386 .6\end{array}$ & $\begin{array}{c}* \\
47.1) \\
176.6 \\
478.6 \\
2436.1\end{array}$ & $\begin{array}{r}1.7 \\
43.6 \\
17 i 1.7 \\
51)(i .8 \\
1.43 i 1.1\end{array}$ & $\begin{array}{r}-1.4 \\
47.1 \\
18.5 .4 \\
525.7 \\
3.114 .2\end{array}$ \\
\hline
\end{tabular}

Note: See note to table 1 .

v Less than $(1,05(8501)$

In 2004 , the most frequently reported motive was retirement-related (34.7 percent of families), and the next most frequently reported was liquidity-related (30.0 percent of families), a response that is generally taken to be indicative of saving for precautionary reasons. ${ }^{11}$ At least since 1995, these have been the dominant reported reasons, but saving for retirement has increased notably in importance. The educationrelated motive also appears to be important; in 2004, 11.6 percent of families reported it as their primary motive. The importance of saving for purchases has fallen over time.

11. I.iquidily-related ratasons include "emergencies;" the possibilidies of unemployment and illness, and the need for reaty money.

\section{NET. WORTH}

From 2001 to 2004, real net worth (wealth) - the difference between families' gross assets and their liabilities - rose, though the mean rose notably more strongly than the median (table 3 ). The median rose 1.5 percent, while the mean rose 6.3 percent; the corresponding values for the period from 1998 to 2001 were 10.3 percent and 28.7 percent $^{12}$

12. The Federal Reserve's flow of lunds accounts provide an estimate of the total net worth of the houschold sector, which includes both households and nonprofil institutions. Petween year-end 2001 and year-end 2004, the flow of lunds estimate of real net worth rose 12.3 percent. Accounting for the 3.6 pereent increase in the number of houscholds ofer this period produces a change in net wrorth about 2 percentage points higher than the SCF estimate of the increase in the mean. 
By age group, median and mean net worth show a "hump" pattern that generally has its peak in the 55-64 age group. This pattern reflects both life-cycle saving behavior and growth in real wages over time. The median and mean values of wealth rise in tandem with income, a relationship reflecting both income earned from assets and a higher likelihood of saving among higher-income families. Wealth shows strong differentials across groups defined in terms of education, racial and ethnic background, work status, and housing status; these differentials generally mirror those for income, but the wealth differences are larger.

\section{Net Worth by Demographic Category}

Analysis by demographic group for the 2001-04 period shows a complicated pattern of gains and losses in median and mean net worth, with changes in the median often opposing those in the mean. The patterns suggest correspondingly complex change in the underlying ownership and values of assets and debts and the distribution of wealth within demographic groups; to some degree, movements of families between groups may also explain some of the shifts in wealth.

Median and mean net worth rose or held about steady for all percentile groups of the distribution of net worth except for families in the lowest 25 percent of the distribution of net worth. In that group, the median rose from $\$ 1,200$ to $\$ 1,700$, up from $\$ 600$ in 1998; the mean fell from near zero to negative $\$ 1,400$, closer to its 1998 value of negative $\$ 2,100$. For the rest of the net worth distribution, growth in the median and mean over the recent three-year period was notable for the groups above the 50th percentile and particularly so for those in the 75-89.9 percentile group; the gains for the groups in the top half of the distribution continued a uniform pattern of gains at least back to 1995 .

Over the recent period, median net worth increased for all income groups above the 40th percentile and especially for the 80-89.9 percentile group, for which the median rose 11.0 percent; the mean for this group was little changed. The mean for the lowest quintile had the largest proportional increase-29.4 percentbut the rise appears to be due to an increase in the fraction of the group consisting of relatively wealthy families with incomes that are likely to have been temporarily low. The mean increased or held about steady for the other income groups, and it rose particularly for the 40-59.9 percentile group-a 13.1 percent gain. Over the preceding years shown, median net worth rose for most income groups; the mean rose for all income groups, but the increases were strongest for the top two income quintiles.

The survey shows some substantial movements of wealth by age group between 2001 and 2004. Median wealth rose most strongly-28.7 percent-for the 55-64 age group, which had also experienced the largest median gain over the previous three-year period. The less-than-35 age group also saw a substantial gain in the median-15.4 percent-over the more recent period; at the same time, median wealth fell 16.0 percent for the 35-44 age group. Mean wealth rose for all age groups except for the lessthan-35 group and the 65-74 group.

More than offsetting gains over the 1998 to 2001 period, median net worth fell 24.3 percent from 2001 to 2004 for families headed by persons with less than a high school diploma or equivalent; the median for the group with some college education also fell, by 9.2 percent. The median rose only for families headed by persons with a high school diploma or equivalent. Mean wealth rose or held about steady for all education groups. For the no-high-school-diploma group, mean wealth rose 24.4 percent; given the large decline in the median for this group, this result suggests a shift in the distribution of net worth within the group. The college-degree group, which had experienced the largest gains in the preceding three-year period, saw little change in its median or mean wealth.

The data show gains from 2001 to 2004 in median and mean wealth for white non-Hispanic families and for nonwhite or Hispanic families, but the gains for the latter were much larger in percentage terms. ${ }^{13}$ For white non-Hispanics, the median rose 8.6 percent, and the mean rose 8.3 percent; for nonwhites or Hispanics, the median rose 29.8 percent, and the mean rose 23.7 percent. However, as was the case with income, these measures of the wealth of nonwhites or Hispanics are far lower than those for other families, and the differences are even larger than those in the case of family income; in 2004, the median wealth of nonwhite or Hispanic families was only 17.6 percent of that for other families. In contrast to the whole group of nonwhite or Hispanic families, the subgroup of African American families saw virtually no change in their median net worth from $2001(\$ 20,300)$ to $2004(\$ 20,400)$, but their

13. If the information on Hispanic or Latino ethnic identification is used in the classification of the 2004 results, the median net worth of: nonwhites or Hispanies was $\$ 27,100$, and the mean was $\$ 162,500$, for other families, the median was $\$ 142,700$, and the mean was $\$ 566,600$. These figures are slightly higher than the corresponding values reported in table 3 
mean net worth rose 37.1 percent, from $\$ 80,700$ to $\$ 110,600$ (data not shown in the tables). Over the 1998-2001 period, the growth of wealth for nonwhites or Hispanics had substantially lagged that for other families.

Among work-status groups, both of the groups in which the family head was currently working saw a decline in median wealth from 2001 to 2004 , while the median rose substantially for the other groups. However, the means show the opposite pattern: gains for those working and losses for the other groups. Over the preceding three years, both median and mean wealth had risen for all work-status groups except for the retired group, which had seen a decline in its median wealth.

Between 2001 and 2004, the mean and median wealth of families increased in all regions of the country except for the South, where the median declined 18.8 percent and the mean fell 13.1 percent. The most striking gain is the 64.5 percent rise in median wealth for the Northeast region, where it had declined in the 1998-2001 period.

By housing status, the mean net worth of homeowners rose 5.1 percent from 2001 to 2004 . The median for homeowners was little changed; for other families, the median fell 21.6 percent, and the mean fell 7.5 percent. This pattern is likely explained in part by the growth in homeownership over the period, as discussed later in this article. New homeowners tend to have less wealth than previously existing homeowners, having had less time to benefit from appreciation of home prices. At the same time, the wealth of the remaining renters will tend to be depressed by rising homeownership because the renter group will have fewer families with assets sufficient to initiate a home purchase. In the preceding three-year period, median and mean wealth had increased for both groups.

\section{ASSETS}

Movements in the dollar value of families' financial assets (tables 4, 5, and 6) and nonfinancial assets (tables 7 and 8) are, by definition, a result of changes in valuation and in the patterns of ownership. The overall proportion of families with any asset rose 1.2 percentage points, to 97.9 percent, in 2004 (first half of tables 8.A and 8.B, last column); this rise continues a trend, at work at least since 1995, that had been interrupted by a pause in 2001 (data not shown in the tables). The largest increases in the proportion holding any asset were in the following demographic groups: the lowest quintile of the income distribution, families headed by persons aged less than 35 and by those aged 65 or older, nonwhite or Hispanic families, families with a head who was not working, renters, and families in the bottom quartile of the wealth distribution. The 2001 ownership levels for other groups were already at or near 100 percent.

Over the recent three-year period, the median real value of assets among families having any asset rose 10.3 percent, from $\$ 156,800$ to $\$ 172,900$ (second half of tables 8.A and 8.B, last column). That gain far exceeds the 1.5 percent rise in median net worth computed for all families regardless of whether they have assets. This divergence suggests that changes in debt holdings, which in some cases appear to have a direct connection to the increased assets of families, are a key factor. Median assets rose substantially for most demographic groups. However, declines were notable for almost all the groups that saw the largest increases in ownership levels - the lowest quintile of the income distribution, the youngest age group, nonwhite or Hispanic families, the other-not-working group, renters, and the lowest quartile of the wealth distribution. One particularly noteworthy increase in the median value of assets was in the 55-64 age group, which saw a rise of 45.7 percent. The prevailing impression from the preceding three years had been one of broad increases in the median. In the recent three-year period, mean assets rose 8.6 percent (second half of tables 8.A and 8.B, memo line).

\section{Financial Assets}

Financial assets as a share of total assets fell 6.3 percentage points from 2001 to 2004 , to 35.7 percent (table 4, memo line); the decline is from a level in

4. Value of financial assets of all families, distributed by type of asset, 1995-2004 surveys

Percent

\begin{tabular}{|c|c|c|c|c|}
\hline $\begin{array}{c}\text { Type of finuncial } \\
\text { asset }\end{array}$ & 1905 & 1948 & 2iiil & $200 i 4$ \\
\hline Transaction acciounts & 13.9 & 11.4 & 11.5 & 13.2 \\
\hline Certificates of deposit & 5.65 & 4.3 & 3.1 & 3.7 \\
\hline Savinges hamds . ...... & 1.3 & .7 & .7 & .5 \\
\hline Eionds & 63 & 4.3 & 4.6 & 53 \\
\hline 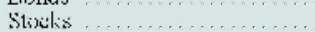 & 15.6 & 22.7 & 21.7 & 17.6 \\
\hline $\begin{array}{l}\text { F'ooled investment finds } \\
\text { (uxcluding moncy mark }\end{array}$ & & & & \\
\hline fundsj .................. & 12.7 & 12.4 & 12.2 & 14.7 \\
\hline 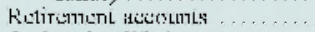 & 28.1 & 27.6 & $2 \times .4$ & $32 . i 1$ \\
\hline Cash value life insurance & 7.2 & 6.4 & 5.3 & 3.61 \\
\hline Other managed assets ... & 50 & 8.6 & 110.6 & 8.1 \\
\hline Ouhet ................ & 3.3 & 1.7 & 2.1 & 2.1 \\
\hline Total & 1(11) & $1(11)$ & 1(ii) & 100.1 \\
\hline MLANO & & & & \\
\hline $\begin{array}{l}\text { Hinancial assocts is is } \\
\text { share of total assets }\end{array}$ & 36.7 & 412.7 & 42.1 & 35.7 \\
\hline
\end{tabular}

NotE: For this and following tables, see text for definition of asset categories. Also see note to table 1 . 
5. Family holdings of financial assets, by selected characteristics of families and type of asset, 2001 and 2004 surveys A. 2001 Survey of Consumer Finances

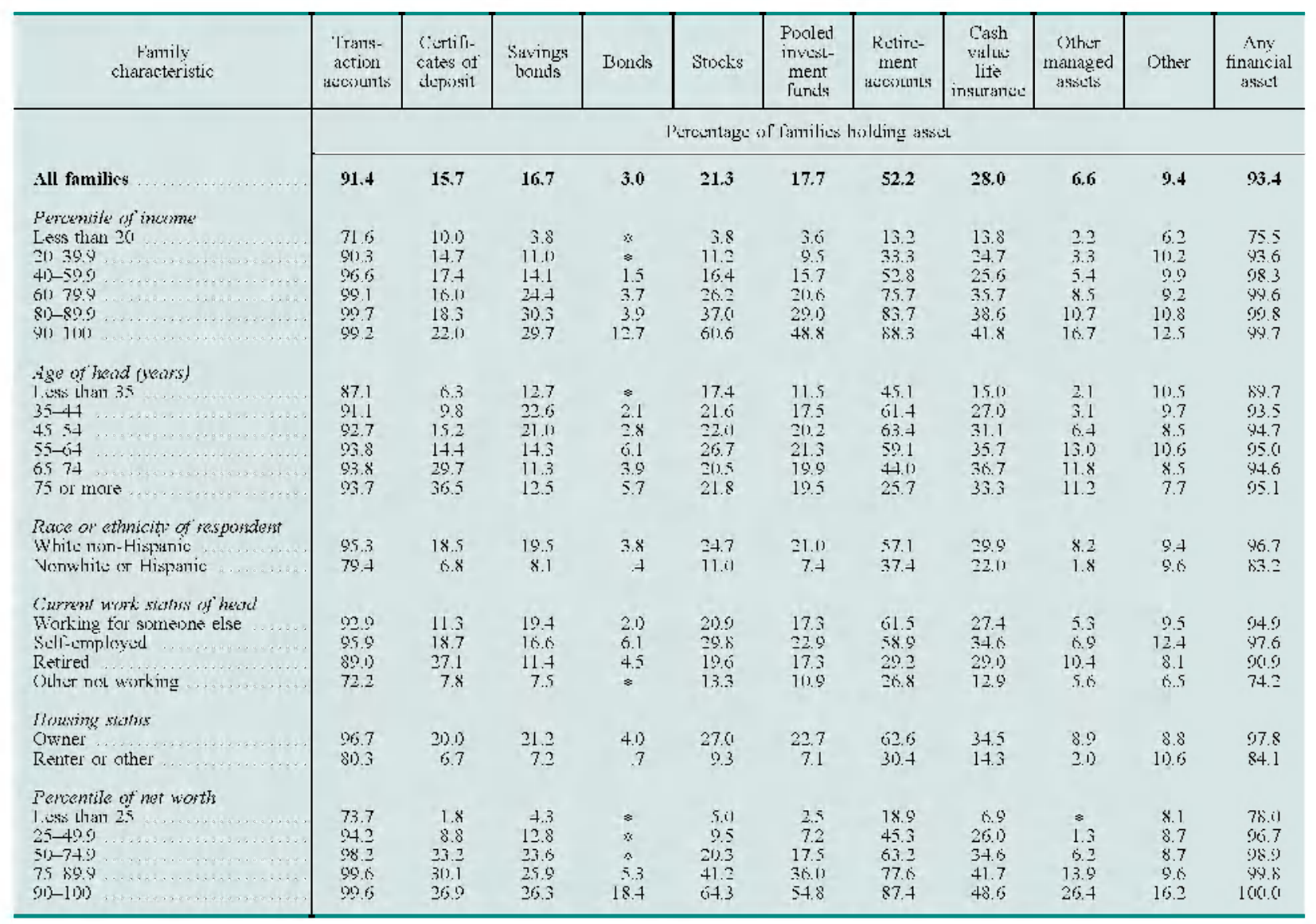

2001 that marked the high point observed in the survey. The relative shares of various financial assets also shifted. Declines in the percentage shares of direct holdings of publicly traded stocks, cash value life insurance, and "other managed assets" were approximately balanced by increases in the shares of retirement accounts, pooled investment funds, and transaction accounts. ${ }^{14}$ After showing a declining trend in earlier survey years, the share of certificates of deposit edged up.

Overall, the ownership of any financial asset over the recent period edged up only 0.4 percentage point, to 93.8 percent (first half of tables 5.A and 5. B, last column). However, the recent data show some pronounced patterns of change for some demographic groups. By income, the largest changes in ownership were a rise for the lowest quintile and a fall for the second quintile; by age, notable increases appeared only for the groups of those 65 or older; and by work status, ownership rose for families headed by people

14. The definitions of assel calegories in table 4 are given below, in the seclions of text devoled to them. who were not working and declined for other workstatus groups. Ownership also rose notably for renters and for nonwhite or Hispanic families.

Paralleling the drop in the overall ratio of financial assets to total assets over the recent period, the median holding of financial assets for families having such assets fell 22.8 percent (second half of tables 5.A and 5.B, last column), while the mean fell 6.9 percent (memo line). The change in the median more than offset the increase over the previous threeyear period. The picture is one of declines in the medians over the recent period for almost every demographic group; exceptions were the eighth income decile and the 55-64 age group. Mean holdings declined for every group (means of groups not shown in the tables).

\section{Transaction Accounts and Certificates of Deposit}

In $2004,91.3$ percent of families had some type of transaction account - a category comprising checking, savings, and money market deposit 
5.-Continued

A. 2001 Survey of Consumer Finances-Continued

\begin{tabular}{|c|c|c|c|c|c|c|c|c|c|c|c|}
\hline $\begin{array}{c}\text { Family } \\
\text { characteristic }\end{array}$ & $\begin{array}{l}\text { 'Trams-s- } \\
\text { action } \\
\text { aćcounts }\end{array}$ & $\begin{array}{l}\text { Corlifi- } \\
\text { cates of } \\
\text { dipposit }\end{array}$ & $\begin{array}{l}\text { Silvings: } \\
\text { bonts }\end{array}$ & Tronds & Stocks & $\begin{array}{l}\text { Pooled } \\
\text { invist- } \\
\text { ment } \\
\text { fundts }\end{array}$ & $\begin{array}{l}\text { Rotite- } \\
\text { ment } \\
\text { ä́coumLs: }\end{array}$ & 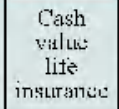 & $\begin{array}{c}\text { (yhir } \\
\text { managed } \\
\text { assuts }\end{array}$ & Other & $\begin{array}{c}\text { Any } \\
\text { financial } \\
\text { assot }\end{array}$ \\
\hline & \multicolumn{11}{|c|}{ 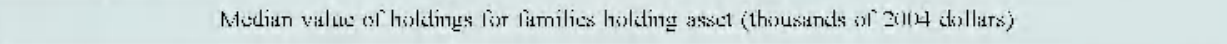 } \\
\hline All families & 4.2 & 16.0 & 1.1 & 46.3 & 21.3 & 37.3 & 30.9 & 10.7 & 74.6 & 4.3 & 29.8 \\
\hline \multicolumn{12}{|l|}{ Percensife of incems } \\
\hline L.ess than 20 & .9 & 1D. 7 & 1.1 & $\ddot{x}$ & 8.1 & 22.4 & 4.8 & 3.8 & 25.8 & 1.8 & 2.1 \\
\hline $20 \quad 394 \ldots \ldots$ & 1.9 & 14.9 & 6 & $\approx$ & $1 i 1.7$ & 256 & $\$ .5$ & 66 & $3 \$ 3$ & 3.2 & $\$ .4$ \\
\hline $41,-505$ & 3.1) & 13.8 & 5 & 11). 7 & 8.5 & 25.6 & 14.5 & 7.5 & 746 & 3.2 & 18.2 \\
\hline 6079.9 & 5.5 & 16.0 & 1.1 & 42.6 & $1 \$ .1$ & $32 . i 1$ & $32 . i$ & 12.8 & 63.9 & 3.2 & 59.1 \\
\hline $817-80.5$ & (1). 1 & 13.8 & 1.1 & 53.3 & 21.3 & 25.8 & 58.6 & 11). 7 & 74.6 & 7.5 & 1013.4 \\
\hline $90100, \ldots \ldots \ldots \ldots$ & 27.7 & 26.6 & 2.1 & 94.5 & 53.3 & 932 & 138.5 & 2.5 .6 & 1193 & 160 & 387.7 \\
\hline \multicolumn{12}{|l|}{ Age of head (t'ens) } \\
\hline 1. vess Lham 35. & 1.9 & 4.3 & $\ldots$ & $\approx$ & 6.1 & $\$ 6$ & 7.11 & 10.7 & 42.6 & 1.7 & 6.6 \\
\hline $35-41 \ldots$ & 3.6 & 6.4 & 1.1 & 14.5 & $16 .(1$ & 18.6 & $3(1.4$ & 96 & 53.3 & 2.1 & 28.6 \\
\hline 4554 & 4.8 & 12.8 & 1.1 & 63.9 & $16 . i 1$ & $41 . i 1$ & 51.1 & 11.7 & 63.9 & 5.3 & $4 i . i$ \\
\hline $55-614$ & 5.0 & 21). 2 & 2.7 & 63.0 & 42.6 & 63.5 & 58.6 & 1D. 7 & 58.6 & 10.7 & 59.8 \\
\hline $6.574 \ldots$. & 8.5 & 21.3 & 2.1 & 76.1 & Si1.5 & 74.6 & 630 & 9.3 & 137.8 & 8.5 & 54.7 \\
\hline 75 dor more & 7.8 & 26.5 & 3.2 & 37.3 & 63.9 & 74.6 & $45)(1$ & 7.5 & 160.5 & 19.2 & 42.6 \\
\hline \multicolumn{12}{|l|}{ Race or ethnicitiv of resporident } \\
\hline White nisn-Hisprinic ........... & 5.1 & 16.0 & 1.1 & $\$ 3.3$ & 23.4 & +2.6 & 37.3 & 10.7 & 74.6 & 5.3 & 41.3 \\
\hline Venwhiti or Hispanic ............ & 1.8 & 9.6 & .7 & 8.1 & $\$ .5$ & $1 \$ .6$ & $1 i 1.7$ & 9.3 & 47.9 & 1.6 & 7.6 \\
\hline \multicolumn{12}{|l|}{ 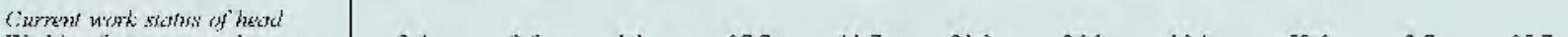 } \\
\hline Working for someione else . & 3.4 & 96 & 1.1 & 27.7 & 11.7 & 21.3 & 20.1 & 11). 1 & 58.6 & 2.7 & 25.7 \\
\hline Soli-smployed & 8.5 & 17.11 & 2.1 & 76.5 & 37.3 & 104.4 & $5 \$ 2$ & 18.1 & 116.1 & 12.8 & $65 . i$ \\
\hline Retiret & 5.3 & 26.5 & 4.3 & 53.3 & 63.5 & 74.6 & 57.5 & 9.5 & 106.5 & 110.7 & 34.4 \\
\hline Ouliut not wirktimes & 1.9 & 42.6 & .3 & $\approx$ & 8.5 & 42.6 & 21.3 & 10.7 & 41.5 & 2.1 & 56 \\
\hline \multicolumn{12}{|l|}{ Nousing sichus } \\
\hline Owner & 6.2 & $16.1)$ & 1.3 & 53.3 & 24.5 & 42.6 & $4(1.7$ & 11). 7 & 74.6 & 5.4 & 53.5 \\
\hline Renter or other & 1.3 & 11). 7 & 4 & 31.5 & 6.7 & 10.7 & 7.2 & $8.1)$ & 42.6 & 2.1 & 4.2 \\
\hline \multirow{2}{*}{\multicolumn{12}{|c|}{ Percentile of net wortis }} \\
\hline 1. Uss Lhan 25 . . . . . . . & & & & & & & 2.1 & 1.9 & $\approx$ & 1.1 & 1.4 \\
\hline $25-4059 \ldots$ & 3.3 & 5.3 & 5 & $\%$ & 3.4 & 5.3 & 8.1 & 5.5 & 10.7 & 2.4 & 11.2 \\
\hline $5(2-7+3)$ & 50 & 13.2 & 1.2 & $\therefore$ & है. & 16.1 & 32.11 & 95 & 23.4 & 4.8 & 56.5 \\
\hline 7589.9 & $1+.5$ & 21.3 & 2.1 & 21.3 & 27.6 & 309 & 81.5 & 12.8 & 74.6 & 10.7 & 214.8 \\
\hline$(91)-1110$ & 38.3 & 42.65 & 2.1 & 55.9 & 125.5 & 145.1 & $21) 2.4$ & $32.1)$ & 213.0 & 35.1 & 753.5 \\
\hline \multicolumn{12}{|l|}{ Mrsio } \\
\hline 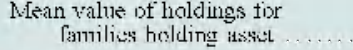 & 2.5 .3 & 39.9 & $\$ .4$ & 310.2 & 204.8 & 1343 & 1043 & 38.4 & 321.5 & 41.9 & 215.6 \\
\hline
\end{tabular}

accounts, money market mutual funds, and call accounts at brokerages. The ownership rate, essentially unchanged from 2001, was 90.6 in the 1998 survey and notably lower before then. Families that did not have any type of transaction account in 2004 were disproportionately likely to have low incomes, to be headed by a person younger than 35 , to be nonwhite or Hispanic, to be headed by a person who was neither working nor retired, to be renters, or to have relatively low levels of wealth. Over the 2001-04 period, ownership rose notably for families at the bottom of the income and wealth distributions, families headed by persons aged 75 or older, families with heads who were not working, nonwhites or Hispanics, and renters.

Underlying the leveling off in the growth of ownership of transaction accounts in the recent three-year period was a larger shift in the types of account families used. The share of families with a checking account rose, and the shares of families with all other types of transaction account declined, as shown in the following table:

\begin{tabular}{|c|c|c|}
\hline \multirow{2}{*}{$\begin{array}{c}\text { Type of } \\
\text { Lrinsaction idecount }\end{array}$} & \multicolumn{2}{|c|}{ Himilies holding } \\
\hline & $\begin{array}{c}2 i j(4) \\
\text { spercent) }\end{array}$ & $\begin{array}{l}\text { (hinge, 2i)ijl-i)4 } \\
\text { (percentage points) }\end{array}$ \\
\hline 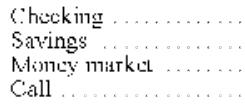 & $\begin{array}{r}89.4 \\
47.1 \\
21.7 \\
2.5\end{array}$ & $\begin{array}{r}2.1 \\
-8.1 \\
-.6 \\
-.7\end{array}$ \\
\hline
\end{tabular}

Most of the change appears to reflect consolidation of multiple types of account into a checking account; for many such families, the relatively low interest rates on deposits may have been insufficient to compensate for the effort of managing multiple accounts. See box "Families without a Checking Account" for a discussion of reasons that some families do not have a checking account.

Median holdings in transaction accounts for those who had such accounts fell 9.5 percent from 2001 to 
5. Family holdings of financial assets, by selected characteristics of families and type of asset, 2001 and 2004 surveys Continued B. 2004 Survey of Consumer Finances

\begin{tabular}{|c|c|c|c|c|c|c|c|c|c|c|c|}
\hline $\begin{array}{c}\text { F'anily } \\
\text { characteristic }\end{array}$ & $\begin{array}{l}\text { 'Trams-s- } \\
\text { action } \\
\text { itcosounts }\end{array}$ & $\begin{array}{l}\text { Corlifi- } \\
\text { cates of } \\
\text { dipposit }\end{array}$ & $\begin{array}{l}\text { Sisvings } \\
\text { bonts }\end{array}$ & Dionds & Stiocks & $\begin{array}{c}\text { Pooled } \\
\text { invisi- } \\
\text { ment } \\
\text { funds }\end{array}$ & 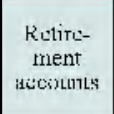 & $\begin{array}{c}\text { Cash } \\
\text { viluk } \\
\text { lite } \\
\text { insutamce }\end{array}$ & $\begin{array}{c}\text { ()his } \\
\text { managed } \\
\text { assuts }\end{array}$ & Other & $\begin{array}{c}\text { Any } \\
\text { financial } \\
\text { assot }\end{array}$ \\
\hline & \multicolumn{11}{|c|}{ 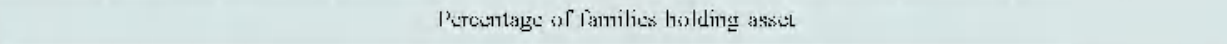 } \\
\hline All families & 91.3 & 12.7 & 17.6 & 1.8 & 20.7 & 15,0 & 49.7 & 24.2 & 7.3 & 10.0 & 93.8 \\
\hline Percensife of incems & & & & & & & & & & & \\
\hline Less than 20 & 75.5 & $5.1)$ & 6.2 & $x$ & 5.1 & 3.6 & 11). 1 & $14.1)$ & 3.1 & 7.1 & $8(1.1$ \\
\hline $2039.9 \ldots$ & 87.3 & 12.7 & 8.8 & $\approx$ & 8.2 & 7.6 & 30.0 & 19.2 & 4.9 & 9.9 & 91.5 \\
\hline $412-505$ & 556 & 11.8 & 15.4 & s & 16.3 & 12.7 & 53.4 & 24.2 & 7.2 & 0.3 & 985 \\
\hline 6079.9 & $8 \times 4$ & 14.9 & 266 & 2.2 & $2 \times .2$ & 18.6 & 69.7 & 29.8 & 7.8 & 11.2 & 0.1 \\
\hline 81$)-80.9$ & 6121 & 16.3 & 32.3 & 2.8 & 35.8 & 26.2 & 81.0 & 20.5 & 12.1 & 11.4 & 598 \\
\hline 100 & lilio,i] & 21.5 & 29.9 & 8.8 & 55.1 & 39.1 & $8 \times .5$ & 38.1 & 13.13 & 13.4 & lijilii \\
\hline tige of thend (years) & & & & & & & & & & & \\
\hline 1. Lss Lita 35.5. & 504 & 5.6 & 15.3 & $\approx$ & 13.3 & 8.3 & 40.2 & 11.0 & 2.9 & 11.6 & iil. 1 \\
\hline $35-44$ & (11).8 & 6.7 & 23.3 & 6 & 18.5 & 12.3 & 550 & 21) 1 & 3.7 & 11).1) & 53.6 \\
\hline 4554 & 91.8 & 11.9 & 21.13 & 1.8 & 23.2 & 18.2 & 57.7 & 2611 & 62 & 12.1 & 93.6 \\
\hline $55-614$ & 93.2 & 18.1 & 15.2 & 3.3 & 29.1 & 21.5 & 630 & 32.1 & 8.4 & 7.2 & 55.2 \\
\hline $6574 \ldots$ & 43.4 & 19.9 & 14.9 & 4.3 & 3.54 & 18.6 & 43.2 & $3+8$ & 12.8 & 8.1 & 46.5 \\
\hline 75 dr mara & 55.4 & 257 & 11.1) & 3.1) & 18.4 & 1656 & 292 & $34.1)$ & 16.7 & 8.1 & 57.6 \\
\hline \multicolumn{12}{|l|}{ Race or ethnicitit of resporadent } \\
\hline White 17 n-Hisplinic .......... & 95.5 & 15.3 & 21.1 & 2.5 & 2.5 .5 & 18.9 & 56.1 & $2+8$ & 9.2 & 10.2 & 97.2 \\
\hline Vennwhitis or Hispanic & $\$ 0.6$ & 6.11 & 8.5 & $\approx$ & $8 . i$ & $5 . i 1$ & 32.9 & 17.4 & 2.1 & 9.4 & $\$ 5, i 1$ \\
\hline \multicolumn{12}{|l|}{ 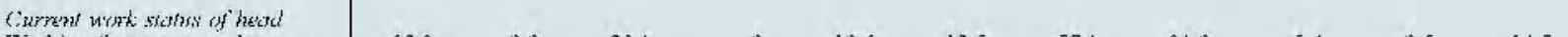 } \\
\hline Working for someione else & 52.2 & 9.8 & 21).1 & .8 & 196 & 13.5 & 57.1 & 21.8 & 5.4 & 0.5 & 94.5 \\
\hline Soli-employed & 94.4 & 14.2 & 18.7 & 4.3 & 31.6 & 22.3 & 54.6 & 29.8 & 7.6 & 1.5 .1 & 96.1 \\
\hline Retiret & (51) 4 & 2). 2 & 11.4 & 3.5 & 1901 & 16.2 & 32.0 & 297 & 12.8 & 8.4 & 53.6 \\
\hline OLliut nest work kime I & 762 & 7.9 & $1+.5$ & $\approx$ & 14.3 & 10.2 & 24.9 & 10.7 & $\approx$ & 11.5 & 796 \\
\hline \multicolumn{12}{|l|}{ Norusing sictus } \\
\hline Owner & $\operatorname{sig}(1$ & 15.9 & 21.2 & 2.65 & 25.8 & 19.2 & (i1) 2 & 31). 1 & 8.65 & 0.65 & 97.5 \\
\hline Renter or other & 811.5 & 56 & 0.5 & 2 & 2.1 & 5.7 & 26.2 & $11.1)$ & 2.1) & 11.9 & 85.5 \\
\hline \multicolumn{12}{|l|}{ Percentile of net worths } \\
\hline 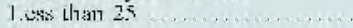 & 7.5 .4 & 2.2 & 6.2 & $\approx$ & 3.6 & 2.0 & 14.3 & 7.7 & $*$ & 69 & 79.8 \\
\hline $25-409$ & 9201 & 6.5 & 13.2 & $\nLeftarrow$ & 0.3 & 7.2 & 43.1 & 12.3 & 2.3 & 0.5 & 50.1 \\
\hline $5(2-7+i)$ & 98.1 & $1(5.1)$ & 23.7 & $\therefore$ & 21.1 & 13.5 & 61.8 & 31). 1 & 8.8 & 10.2 & 9.4 \\
\hline 7589.9 & 99.7 & 24.2 & 28.5 & 3.2 & 39.1 & 32.4 & 77.6 & 367 & 1.5 .6 & 11.2 & lilij.il \\
\hline$(91)-1130$ & $1(11)(1$ & 28.8 & 28.1 & 12.7 & 63.5 & 47.3 & 82.5 & 43.8 & $21.1)$ & 16.4 & 10010 \\
\hline
\end{tabular}

2004, while the mean rose 7.1 percent. Across demographic groups, the patterns of change in the median are mainly a mixture of substantial increases and declines. Median balances fell for the lowest two income groups and the lowest three wealth groups but rose or held steady for the other income and wealth groups. Across age groups, the median increased only for the 55-64 group and fell or was unchanged for other families. By work status, median balances rose substantially for the self-employed group. Holdings declined for both of the racial and ethnic groups and for both of the housing-status groups.

Certificates of deposit (CDs)-interest-bearing deposits with a set term - are traditionally viewed as a low-risk saving vehicle, and they are often used by people who desire a safe haven from the volatility of financial markets. Over the 2001-04 period, the attractiveness of CDs declined as the interest rates on them fell. The resulting 3.0 percentage point decline in ownership broke the slow upward movement seen since 1998. Over the more recent period, ownership declined among most demographic groups. At the same time, the overall real median value fell 6.3 percent. Across income groups, declines in the median were concentrated in the groups below the 60th percentile, whereas the medians for the higher-income groups increased; along with the fact that the overall mean holding rose 37.6 percent, this result suggests that the concentration of $\mathrm{CD}$ balances rose among the higher-income groups. The median value of CDs rose for all wealth groups except the third quartile.

\section{Savings Bonds and Other Bonds}

Savings bonds are owned disproportionately by families with incomes in the highest 40 percent of the distribution and by families in the top half of the distribution of net worth. Over the 2001-04 period, the ownership of savings bonds rose 0.9 percentage point overall, and it rose for most demographic groups; these gains partially offset declines in the preceding three-year period. Median holdings fell 9.1 percent, and the mean fell 31.0 percent between 2001 and 2004. 
5.-Continued

B. 2004 Survey of Consumer Finances-Continued

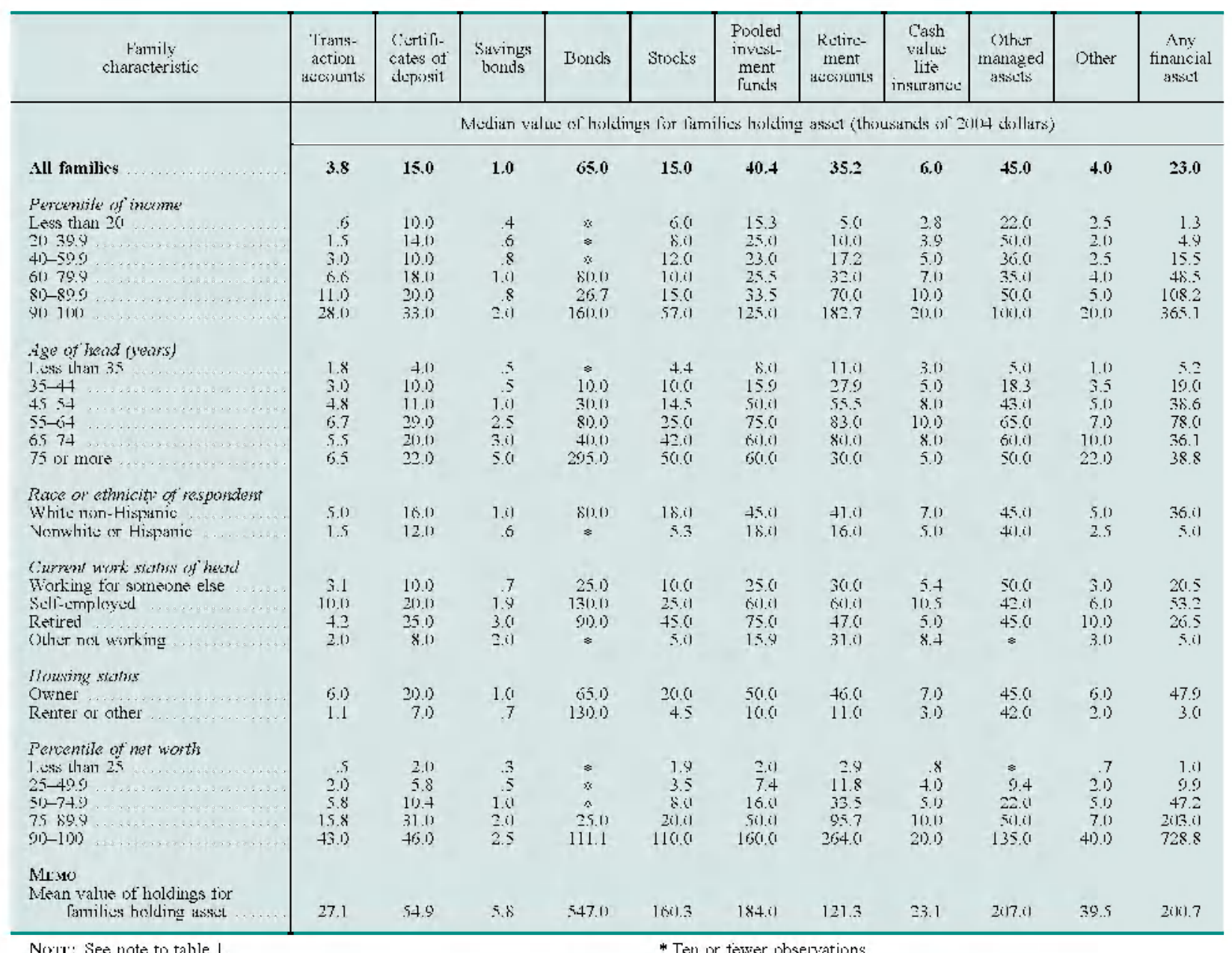

Other bond types tend to be very narrowly held, and the ownership rate, which had been flat since 1995 , fell to 1.8 percent in 2004 , a drop of 1.2 percentage points from 2001. ${ }^{15}$ The underlying data in the survey suggest that, among families that owned bonds, the proportion that owned mortgage-backed bonds and corporate or foreign bonds rose in the recent period, while ownership of tax-exempt and other government bills and bonds fell somewhat. Ownership of any type of bond is notably concentrated among the highest tiers of the income and wealth distributions, and these groups saw comparatively large declines in ownership from 2001 to 2004. At the same time, the value of bonds for families

15. "Other bonds" as reported in the survey are held direcily and include sorporate and nortgage-backed bonds; foderal. state, and local government bonds: and foreign bonds. In the survey. financial assets held indireclly are those held in retirement accounts and in olher managed assels. that had them rose substantially; the median went up 40.4 percent and the mean 76.3 percent.

\section{Publicly Traded Stock}

The direct ownership of publicly traded stocks is more widespread than the direct ownership of bonds, but, as with bonds, it is also concentrated among high-income and high-wealth families. The share of families with any such stock holdings declined 0.6 percentage point from 2001 to 2004 after having risen steadily since the 1995 survey. Over demographic groups, the decline was most marked for the highest decile of the income distribution.

Although the major stock price indexes had declined in 2001 to about the levels of 1998 and had recovered by the time of the 2004 survey, the median amount of directly held stock for families with such assets was 29.6 percent lower in 2004 than in 2001; 


\section{Families without a Checking Account}

Between 2001 and 2004, the proportion of families with any type of transaction account barely changed (table 5), while the share without a checking account fell 2.1 percentage points, from 12.7 percent to 10.6 percent (data not shown in the tables). The decline in the fraction of families without a checking account follows a longer trend; in 1992 , the share was 16.6 percent ${ }^{7}$

Among families without a checking account in 2004 , 52.1 percent had held such an account in the past, 55.1 percent had incomes in the lowest 20 percent of that distribution, 56.6 percent were headed by persons younger than 45 , and 61.0 percent were nonwhite or Hispanic.

The SCF asked all families that did not have a checking account to give a reason for not having an account (see table). The most commonly reported reason - given by 27.9 percent of families - was that the family did not write enough checks to make account ownership worthwhile. Another 14.4 percent said that they did not have enough money to make account ownership worthwhile, and 22.6 percent said that they did not like dealing with banks. The pattern of the reported reasons differs only slightly from that in 2001 .

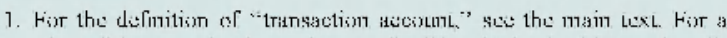
discussion of the ways that lower-income families pltain checking and credit

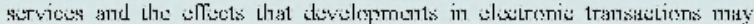
have on such tamilies, see Teanne M. IIogarth and Kerin II. O'Donnell

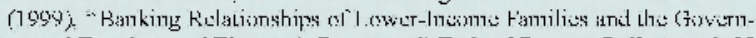
mental Trent toward Electronic Payments," Federal Resene Eulletis, viol. 85 (Iuly). pp. 4.5973.
When attention is further restricted to families that once had a checking account (data not shown in the table), the general pattern of: responses is similar to that for all families without a checking account, but there were some notable changes over the period. For families that once had a checking account, the proportion reporting that they could not manage a checking account or did not like banks both rose from 2001. These increases are offset by decreases in the proportion reporting that they found service charges too high, did not write enough checks, had credit problems, or did not have enough money for an account to be worthwhile.

Distribution of reasons cited by respondents for their families' not having a checking account, by reason, 1995-2004 surveys

P'Erest1

\begin{tabular}{|c|c|c|c|c|}
\hline RLasion & 1995 & 1998 & 20001 & 201014 \\
\hline Do not write enough checks & 953 & $78 x$ & 726 & 77 \\
\hline 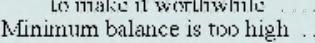 & 88 & 8.75 & 6.5 & 5.6 \\
\hline 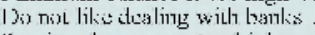 & 18.6 & 18.5 & 22.6 & 22.6 \\
\hline Serviec chirtects are lis high .. & $\$ .4$ & 11.0 & $1 i 1.2$ & 11.6 \\
\hline $\begin{array}{l}\text { Cannot manage or balance } \\
\text { it chueviming acursunt }\end{array}$ & Nat & 73 & 66 & $\therefore 8$ \\
\hline No bank has convenient hours & & & & \\
\hline or lecation............ & 1.2 & 1.2 & 4 & 1.1 \\
\hline Do not have enough money & 201.1 & 12.9 & $14 .(1$ & 14.4 \\
\hline (Tudit problums................. & 1.4 & 2.7 & 3.6 & 2.4 \\
\hline 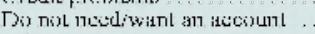 & +4 & 63 & 5.1 & 5.. \\
\hline Other $\ldots . . . \ldots \ldots \ldots . . . . .$. & 3.5 & 3.1 & 2.4 & 2.4 \\
\hline |bolal & liki & 1603 & 100.9 & 1010 \\
\hline
\end{tabular}

the mean was 21.7 percent lower. The declines in the median and mean were shared by most demographic groups (means for groups not shown in the tables); a notable exception was the increase in the median for the third income quintile, 41.2 percent.

The great majority of families owned stock in only a small number of companies. In 2004, 34.6 percent had stock in only one company, 59.5 percent had stock in three or fewer companies, and 9.5 percent had stock in fifteen or more companies (data not shown in the tables). For 37.1 percent of stock owners, at least one of the companies was one that employed or had employed the family head or that person's spouse or partner. The 2001 data show a similar pattern.

\section{Pooled Investment Funds}

From 2001 to 2004 , direct ownership of pooled investment funds fell 2.7 percentage points, to
15.0 percent of families ${ }^{16}$ Typically, the pattern of ownership of pooled investment funds resembles that of stocks, but in contrast to the mixed changes in stock ownership over this period, ownership of pooled investment funds declined for almost every demographic group. Both the overall change and the changes for demographic groups break an earlier trend toward broadly increased ownership of this asset. Among families owning pooled investment funds, the survey indicates that ownership shifted over the recent period from funds largely invested in either stocks or government bonds toward funds dedicated to a balance between stocks and bonds of any type. For 2004, the survey for the first time provides separate information on a miscellaneous category of funds, which is composed of hedge funds, exchange-

16. Pooled investment lunds in this article are laken to exclucte moncy market mutual finds and indirectly held mutual finds and to include all other types of direstly held pooled infestment funds. such as tratitional open-end and closed-end mulual lunds, real estate investment trusts, and hetge luncts. 
traded funds, and similar instruments; the survey estimates that 4.3 percent of families with pooled investment funds ( 0.7 percent of all families) had funds of this type (data not shown in the tables).

Among families owning pooled investment funds, the value of holdings has continued an increase seen over the preceding decade; in the recent period, the median holding rose 8.3 percent, and the mean rose 32.1 percent. Among the top quintile of the income distribution, where ownership is most prevalent, the median holding rose substantially over the recent period; holdings fell for the other income groups. At the same time, median holdings across wealth groups fell only for the lowest quartile. By age, holdings rose only for the 45-64 age groups. Median holdings rose for white non-Hispanic families and fell for other families.

\section{Retirement Accounts}

Ownership of tax-deferred retirement assets such as individual retirement accounts (IRAs) tends to increase with families' income and net worth. ${ }^{17}$ For several reasons, ownership is also more likely among families headed by persons less than 65 years of age than among the older groups. First, even though retirement accounts have been in existence for about twenty years, they may not have become common until relatively late in the careers of people in the older groups. Second, beginning in the year that a person reaches age 591/2, funds held by that person in retirement accounts may be withdrawn without penalty, and some in the group may have done so. Third, families may have used funds from retirement

17. Tax-delerred retirement accounis consist of IRAs, Keogh accounis, and extain employer-sponsored accounis. Fimployersponsored accounts consist of $401(k)$. $403(b)$. and thrift sawing accounts from current or past jobs: other current job plans from which loans or withdrawals can be mate; and accoumts from pasi jobs lrom which the family expects to receive the account balanes in the future. This definition of enployer-sponsored plans is intended to confine the analysis to accounts that are portable across jobs and for which families will ultimaicly have the option to withdraw the balance.

IR $\mathrm{As}$ and Kcoglis inay be invested in virtually any asset. including stocks, bonds, pooled inwestment funds. options. and real estate. In principle, employer-sponsored plans may be invested in a similarly broad way, but. in practice, individuals" choices for investuncent are often linited to a narrofrer set of assets. The 2004 SCF introdued at new secuence of questions to cover employer-sponsored pensions associated with the current jobs of the survey respondent and the spouse or partner of that person. The goal of this redesign was to better cope with the proliferation of complex plans and with the confusion many people appear to hate about the exact types of their plans. Although the new sequence was designed to contain the earlier questions. it is still possible that the new eontext nay have changed patterns of response for some types of respondent in ways nol compatible with the earlier tata. accounts accumulated from previous employment to purchase an annuity at retirement; annuities are treated in this article as a separate type of managed asset.

From 2001 to 2004 , the fraction of families with retirement accounts fell 2.5 percentage points; the drop offset most of the 3.3 percentage point increase of the preceding three years. In the recent period, more than 60 percent of families with some type of account plan had one associated with a current or past job, and nearly as many had an IRA or Keogh account; about one-fourth of families with retirement accounts had both types (data not shown in the tables). Over this time, ownership declined for nearly all groups; key exceptions were families with a retired head and families headed by persons aged 55 to 64 or aged 75 or older. In the preceding three years, ownership had been up in almost every demographic group.

In a continuation of the trend over the preceding decade, holdings in retirement accounts increased markedly in the 2001-04 period; for those having retirement accounts, the median rose 13.9 percent, and the mean rose 11.0 percent. Gains also appeared in the median holdings of most demographic groups over the recent period; one of the largest increases was among nonwhite or Hispanic families, a group for which ownership of such accounts declined substantially in 2004 . The 75 -or-older age group saw a sizable decline in its median.

Although tax-deferred retirement assets are clearly an important element in retirement planning, families may hold a variety of other assets that are intended, at least in part, to finance retirement. Such other assets might also be used for contingencies as necessary. Similarly, a need for liquidity might drive a family to liquidate or borrow against a tax-deferred retirement asset, even if it will be assessed a penalty for doing so.

Two common and often particularly important types of retirement plan are not included in the assets described in this section: Social Security (the federally funded Old-Age and Survivors' Insurance program, or OASI) and employer-sponsored definedbenefit plans. OASI is well described elsewhere, and it covers the great majority of the population. ${ }^{18}$ The retirement income provided by defined-benefit plans is typically based on workers' salaries and years of work with an employer, a group of employers, or a union. Unfortunately, income streams from OASI and

18. lior a detailed description of OASI. sec Social Security 1 dninistration, "Online Social Security Handbook," T'ublication 65-008, wur.ssa.gow OP_Home handbookissa-libk.h1m. 
defined-benefit plans cannot be translated directly into a current value because valuation depends critically on assumptions about future events and conditions - work decisions, earnings, inflation rates, discount rates, mortality, and so on-and no widely agreed-upon standards exist for making these assumptions. ${ }^{19}$

However, the SCF does contain substantial information for family heads and their spouses or partners regarding their defined-benefit plans and plans with some type of account feature to which they have rights from a current or past job. ${ }^{20}$ In 2004, 57.5 percent of families had rights to some type of plan other than OASI through the current or past work of either the family head or that person's spouse or partner, a level nearly the same as in 2001 . Of this group of families, 57.4 percent had a plan that was a standard defined-benefit plan with an annuity payout scheme, 62.8 percent had a plan with at least some account feature, and 20.1 percent had both types of plan (data not shown in the tables).

In many pension plans with account features, contributions may be made by the employer, the worker, or both. In some cases, these contributions represent a substantial amount of saving, though workers may offset this saving by reducing their saving in other forms. An employer's contributions also represent additional income for the worker. In 2004, 88.5 percent of families with account-type plans on a current job of either the family head or the spouse or partner of the family head had employers who made contributions to the plan, and 89.4 percent of families with such plans made contributions themselves (data not shown in the tables). The median annual contribution by employers who contributed to such accounts was $\$ 2,400$, and the median contribution of families that contributed was $\$ 2,700$.

The eligibility of working heads of families to participate in any type of job-related pension fell from 57.2 percent in 2001 to 54.8 percent in 2004; it had risen 2.0 percentage points over the preceding

19. For one possible calculation of net worth that incluctes the annuity value of defined-bencfit pension benefits and $O$ ASI paynents, see Arthur B. Kennickell and Amika L. Sundén (2005), "Pensions, Social Security, and the Distribution of Weal h," Finanee and Feonomics Discussion Scries 1997-55 (Washington: 13oard of Governors of the liederal Resertie System. Otober). Www federalreserve.gow: pulsileds: 1997index.hinl.

20. The definition of account plan here diflers slightly from that used in computing the survey wealth measure, which includes aceount balances only il the lamily has the ability to make withdrawals liom. or borrow against, the account. Here the only eriterion used in classification is whether there is any account balance. For example, a defincd-bencfit plan with a portable sash option. which wrould allow the covered worker to recive a lump sum in lieu ol regular payments in retirement, would be treated as an account plan here. three years (data not shown in the tables). Participation by eligible workers is usually voluntary. In 2004 , 84.1 percent of family heads who were eligible to participate elected to do so, down from 85.2 percent in 2001. ${ }^{21}$ The choice to participate appears to be related strongly to income. Of heads of families with incomes in the lowest 20 percent of the distribution in $2004,50.6$ percent who were eligible declined to participate; in contrast, among heads of families with incomes in the highest 10 percent of the distribution, only 5.0 percent of eligible workers declined to participate.

\section{Cash Value Life Insurance}

Cash value life insurance combines an investment vehicle with insurance coverage in the form of a death benefit ${ }^{22}$ Some cash value life insurance policies offer a high degree of choice in the way the policy payments are invested. Investment returns on such policies are typically shielded from taxation until the money is withdrawn; if the funds remain untapped until the policyholder dies, the beneficiary of the policy may receive, tax-free, the death benefit or the cash value, whichever is greater. In contrast, term insurance, the other popular type of life insurance, offers only a death benefit. One attraction of cash value policies for some people is that they promote regular saving funded through the required policy premium.

Ownership of cash value insurance is broadly spread across demographic groups, with a tendency toward increasing rates among families with higher levels of income and wealth and those with older family heads. Ownership of cash value policies over the 2001-04 period continued a declining trend, decreasing 3.8 percentage points, to 24.2 percent of families. The decline was shared by nearly all the demographic groups. Over this time, the ownership of either cash value or term life insurance also fellfrom 69.3 percent to 65.4 percent of families (data

21. An analysis of the Harch CPS with a definition of fanily head that is closest to that in this article shows a sinilar trend in pension eligibility lor employed lamily heads, but that trend is at a somewhal ligher level than in the SCF. The C'PS eligibility estimate for family lweads with a job in the past year was 61.9 percent in 2001 and 57.8 percent in 2004. Dillerences in the definition of the relevant employment may explain some of the dillerence in the levels in the two surveys. Lnlike the SCF. the CPS shows a small increase in the uptake rale for such eligible workers-from 82.9 percent in 2001 to 83.4 percent in 2004

22. The surfey neasures the ralue of such policiss ascording to their current cash falue. not their death benefit. The eash yalue is inclucted as an asset in this arlicle only when there was a nonzero cash value at the time of the interview. 
not shown in the tables). Of those families with some type of life insurance, the proportion with term policies rose, while the proportion with cash value policies fell; these changes follow earlier trends in the survey.

After rising fairly strongly over the period from 1992 to 2001, the median value of cash value insurance for families that had any fell 43.9 percent between 2001 and 2004, and the mean fell 39.8 percent. The median showed sizable declines in every demographic group shown. Percentage declines were most notable among families in the bottom quartile of the wealth distribution, among younger families, and among renters.

\section{Other Managed Assets}

Ownership of other managed assets-personal annuities and trusts with an equity interest and managed investment accounts-is concentrated among families with higher levels of income and wealth and among families headed by persons who are aged 55 or older or who are retired. ${ }^{23}$ Ownership of these assets rose 0.7 percentage point between 2001 and 2004 after a similarly small increase over the previous three years. Across demographic groups, changes in ownership were mixed; ownership increased most-5.5 percent-for the oldest age group, and it decreased most-5.4 percent-for the highest wealth group. Of families having such accounts in 2004, 26.3 percent had only a trust or managed investment account, 68.9 percent had only an annuity, and 4.9 percent had both (data not shown in the tables).

23. The survey encourages respondents who have trusts or managed investment accounts that are held in relatively common invest-

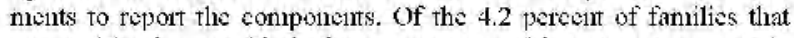
reported having any kind of trust or managed investment aceount in 2004, 45.1 percent of them reporied at least one of the component assets separately. Of families that detailed the components in 2004 , 87.2 perecent reported some type of financial asset, 11.0 perecnt reported a primary residence, 13.4 percent reported other real estats, 3.6 percent reported a business, and 2.7 percent reported another lype of asset (data not shown in the tables). Comparable figures are 10 t available for 2001

In this article, the trust or managed investment accounts included in other managed assets are those in which families luawe an equity interest and for which component parts were not separately reported. Typically, such accounts are those in which the ownership is compliealed or lla management is undertaken by a prolessional. In 2004. 79.0 percent of fanilies with trusts or managed investment accounts hat an equity interest in those accounts. Annuities may be those in which the lamily has an equity interest in the asset or in which there is an entitlement only to a streain of income. The frealth figures in this article include only the amuities in which there is an equity interest. In 2004, 7.2 percent of lamilies reporked having any type of annuity, and of these lamilies, 81.8 percent reported having an equity inierest.
Between 2001 and 2004, the median value of other managed assets fell 39.7 percent, and the mean fell 35.6 percent. During the preceding three-year period, the median had more than doubled. Over the recent period, median holdings declined for almost all demographic groups. The declines reflect substantial reductions both in annuities and in trusts or managed investment accounts. For families with an equity interest in an annuity, the median holding fell 30.6 percent, to $\$ 37,000$, in 2004 ; for families with a trust or managed investment account as defined in this article, the median holding fell 37.4 percent, to $\$ 100,000$ (data not shown in the tables).

As noted in the discussion of retirement accounts, some families use settlements from retirement accounts to purchase an annuity. In 2004, 26.7 percent of families with annuities had done so (data not shown in the tables). Of these families, 91.6 percent had an equity interest in their annuities.

\section{Other Financial Assets}

For other financial assets - a heterogeneous category including oil and gas leases, futures contracts, royalties, proceeds from lawsuits or estates in settlement, and loans made to others - ownership rose 0.6 percentage point between 2001 and 2004, to 10.0 percent. Ownership of such assets tends to be more common among higher income and wealth groups, younger age groups, and families headed by a person who is self-employed. Changes in ownership across demographic groups were generally positive, while the median holding for those who had such assets fell 7.0 percent, to $\$ 4,000$.

Some publicly traded companies offer stock options to their employees as a form of compensation ${ }^{24}$ Although stock options, when executed, may represent an appreciable part of a family's net worth, the survey does not specifically ask for the value of these options. ${ }^{25}$ Instead, the survey asks whether the family head or that person's spouse or partner had been given stock options by an employer during the preceding year. In 2004, 9.3 percent of families reported having received stock options, a share 2.1 percentage points below the level in 2001 (data not shown in the tables).

24. See David J ebow, Iouise Sheiner, Iarry Sliliman, and Marlia Starr-HeClucr (1999), "Recent Trends in Compensation Practices." Finance and Feonomics Discussion Series 1999-32 (Wiahington: Board of Covernors of the Federal Reserve System, Tuly).

25. Because such options are typically not publicly traded or their execution is othervise constrained, their value is uncertain until the exercise date; until then, meaninglul valualion would recuire complex assumptions about the luture behavior of stock prices. 
6. Direct and indirect family holdings of stock, by selected characteristics of families, 1995-2004 surveys Percent except as noted

\begin{tabular}{|c|c|c|c|c|c|c|c|c|c|c|c|c|}
\hline \multirow{2}{*}{$\begin{array}{l}\text { Family } \\
\text { iluaracturistic }\end{array}$} & \multicolumn{4}{|c|}{ r'muliliss with hasldiness } & \multicolumn{4}{|c|}{$\begin{array}{l}\text { Median value among tamilies } \\
\text { with holdings: } \\
\text { (thousands of } 2101 \text { ) } 4 \text { dollars) }\end{array}$} & \multicolumn{4}{|c|}{$\begin{array}{l}\text { 'lital stock holdings as a shirte } \\
\text { of total tinancial assets }\end{array}$} \\
\hline & 1505 & 1908 & 21301 & $2(1114$ & 1005 & 1008 & $2(101)$ & 21104 & 1595 & 1008 & $2(101)$ & 210104 \\
\hline All limilies ... & 40.4 & 48.9 & 51.9 & 48.6 & 18.0 & 29.0 & 36.7 & 24.3 & 40.1 & 54.0 & 56.0 & 47.4 \\
\hline 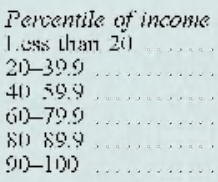 & $\begin{array}{l}6.5 \\
24.7 \\
41.5 \\
54.3 \\
64.7 \\
80.11\end{array}$ & $\begin{array}{l}10.0 \\
310.8 \\
.50 .2 \\
690.3 \\
77.9 \\
010.4\end{array}$ & $\begin{array}{l}12.4 \\
33.5 \\
5.1 \\
75.7 \\
82.11 \\
85.6\end{array}$ & $\begin{array}{l}11.7 \\
28.8 \\
49.2 \\
655.5 \\
82.5 \\
91.1\end{array}$ & $\begin{array}{r}4.6 \\
7.8 \\
7.7 \\
15.6 \\
3 i 1.8 \\
73.5\end{array}$ & $\begin{array}{r}5.8 \\
11.5 \\
13.9 \\
22.1 \\
52.2 \\
156.5\end{array}$ & $\begin{array}{r}7.4 \\
8.01 \\
16.11 \\
31) .4 \\
68.8 \\
203.8\end{array}$ & $\begin{array}{r}7.0 \\
8.8 \\
11.6 \\
2(1.1) \\
34.6 \\
169.9\end{array}$ & $\begin{array}{l}14.2 \\
26.7 \\
28.5 \\
35.6 \\
41.3 \\
45.7\end{array}$ & $\begin{array}{l}3 i 1.4 \\
25.8 \\
35.1 \\
45.8 \\
5 i 1.4 \\
62.5\end{array}$ & $\begin{array}{l}36.9 \\
34.0 \\
46.5 \\
51.7 \\
57.4 \\
601.5\end{array}$ & $\begin{array}{l}31.3 \\
29.6 \\
41 . i 1 \\
37.5 \\
43.2 \\
53.6\end{array}$ \\
\hline $\begin{array}{l}\text { Age of hend (bears) } \\
\text { Less than } 35 \\
35 \text { t4 } \\
45-54 \\
55 \text { } 64 \\
65-74 \\
75 \text { or mome }\end{array}$ & $\begin{array}{l}36.6 \\
46.4 \\
48.5 \\
41.11 \\
34.4 \\
27.9\end{array}$ & $\begin{array}{l}41) .8 \\
56.7 \\
58.6 \\
5.5 .9 \\
42.7 \\
29.4\end{array}$ & $\begin{array}{l}48.5 \\
59.5 \\
55.2 \\
57.1 \\
35.2 \\
34.2\end{array}$ & $\begin{array}{l}38.8 \\
52.3 \\
54.4 \\
61.6 \\
45.8 \\
34.8\end{array}$ & $\begin{array}{l}6.3 \\
12.3 \\
31.5 \\
3 \$ .2 \\
41.5 \\
24.6\end{array}$ & $\begin{array}{r}8.1 \\
23.2 \\
44.1 \\
54.5 \\
64.9 \\
69.6\end{array}$ & $\begin{array}{r}7.5 \\
29.3 \\
53.3 \\
86.5 \\
150.8 \\
127.8\end{array}$ & $\begin{array}{r}5.2 \\
12.7 \\
3(1.6 \\
59.5 \\
75.1) \\
8.9\end{array}$ & $\begin{array}{l}27.2 \\
39.5 \\
4.3 .1 \\
+1.5 \\
35.8 \\
39.8\end{array}$ & $\begin{array}{l}44.9 \\
55.11 \\
55.7 \\
58.4 \\
51.3 \\
48.7\end{array}$ & $\begin{array}{l}52.5 \\
57.3 \\
59.1 \\
56.2 \\
55.2 \\
51.4\end{array}$ & $\begin{array}{l}31)(1 \\
47.7 \\
46.8 \\
51.1 \\
51.1 \\
39.1\end{array}$ \\
\hline $\begin{array}{l}\text { Noswing scichss } \\
\text { Owner } \\
\text { Kunter ar wher }\end{array}$ & $\begin{array}{l}48.8 \\
25 . i 1\end{array}$ & $\begin{array}{l}50.8 \\
27.5\end{array}$ & $\begin{array}{l}62.1 \\
3 i 1.7\end{array}$ & $\begin{array}{l}50.1 \\
2.5 .1\end{array}$ & $\begin{array}{r}22.2 \\
7.9\end{array}$ & $\begin{array}{r}39.4 \\
\$ .7\end{array}$ & $\begin{array}{r}53.3 \\
7.5\end{array}$ & $\begin{array}{r}34.4 \\
6.7\end{array}$ & $\begin{array}{l}41.1 \\
32.4\end{array}$ & $\begin{array}{l}55.1 \\
4 i .5\end{array}$ & $\begin{array}{l}56.7 \\
46.2\end{array}$ & $\begin{array}{l}48.0 \\
3.5 .5\end{array}$ \\
\hline
\end{tabular}

NoTE: Indirect holdings are those in retirement accounts and other managed assets. See also note to table 1 .

\section{Direct and Indirect Holdings of Publicly Traded Stocks}

Families may hold stocks in publicly traded companies directly or indirectly, and information about each of these forms of ownership is collected separately in the SCF. When direct and indirect forms are combined, the 2004 data show a break in a trend of increasing stock ownership dating to before the 1995 survey (table 6). Between 2001 and 2004, the fraction of families holding any such stock fell 3.3 percentage points, to 48.6 percent, a level apparently last reached some time between the 1995 and 1998 surveys. Much like ownership of directly held stock, ownership of direct and indirect holdings is more common among higher-income groups and among families headed by persons aged 35 to 64 . Over the recent three-year period, ownership declined for all income groups except the top two deciles and for the age groups 55 or older.

At the same time, the overall median value of direct and indirect stock holdings dropped 33.8 percent. The decline was shared by all the demographic groups shown except for families in the second quintile of the income distribution, a group with a rate of ownership that is much below the average. As a proportion of financial assets, holdings declined 8.6 percentage points overall and also fell substantially for every demographic group shown.

Among families that held stocks in 2004, 78.2 percent held them through a tax-deferred retirement account, 42.5 percent through direct holdings of stocks, 29.4 percent through direct holdings of pooled investment funds, and 9.7 percent through a managed investment account or an equity interest in an annuity or trust (data not shown in the tables); 44.0 percent had ownership through more than one such means. Regarding the distribution of the amount of directly and indirectly held equities, 30.8 percent was held in tax-deferred retirement accounts, 37.1 percent as directly held stocks, 24.1 percent as directly held pooled investment funds, and 8.0 percent as other managed assets.

\section{Nonfinancial Assets}

By definition, a rise in nonfinancial assets as a share of total assets must exactly offset the 6.3 percentage

7. Value of nonfinancial assets of all families, distributed by type of asset, 1995-2004 surveys P'ircent.

\begin{tabular}{|c|c|c|c|c|}
\hline Type of asset & 1905 & 1998 & $2(1011$ & 2)(14 $(14$ \\
\hline Vehickss ......... & 7.1 & 6.5 & 5.9 & 5.1 \\
\hline F'rimary residence & 47.5 & $47.1)$ & 45.9 & 501.3 \\
\hline Olher Tesidential preperty & 8.0 & 8.5 & 8.1 & 9.9 \\
\hline 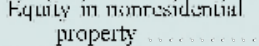 & 7.9 & 7.7 & 8.2 & 7.3 \\
\hline Piusiniss cijuily ...... & 27.2 & $2 \times .5$ & 29.3 & 250 \\
\hline Other .......... & 3.3 & 1.7 & 1.6 & 1.5 \\
\hline 'liblit & 7010 & 1010 & litio & liki \\
\hline MFMO & & & & \\
\hline 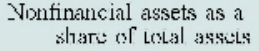 & 63.3 & 59.3 & 58.11 & 64.3 \\
\hline
\end{tabular}

NoTE: See note to table 1 and text note 26 . 
8. Family holdings of nonfinancial assets and of any asset, by selected characteristics of families and type of asset, 2001 and 2004 surveys

A. 2001 Survey of Consumer Finances

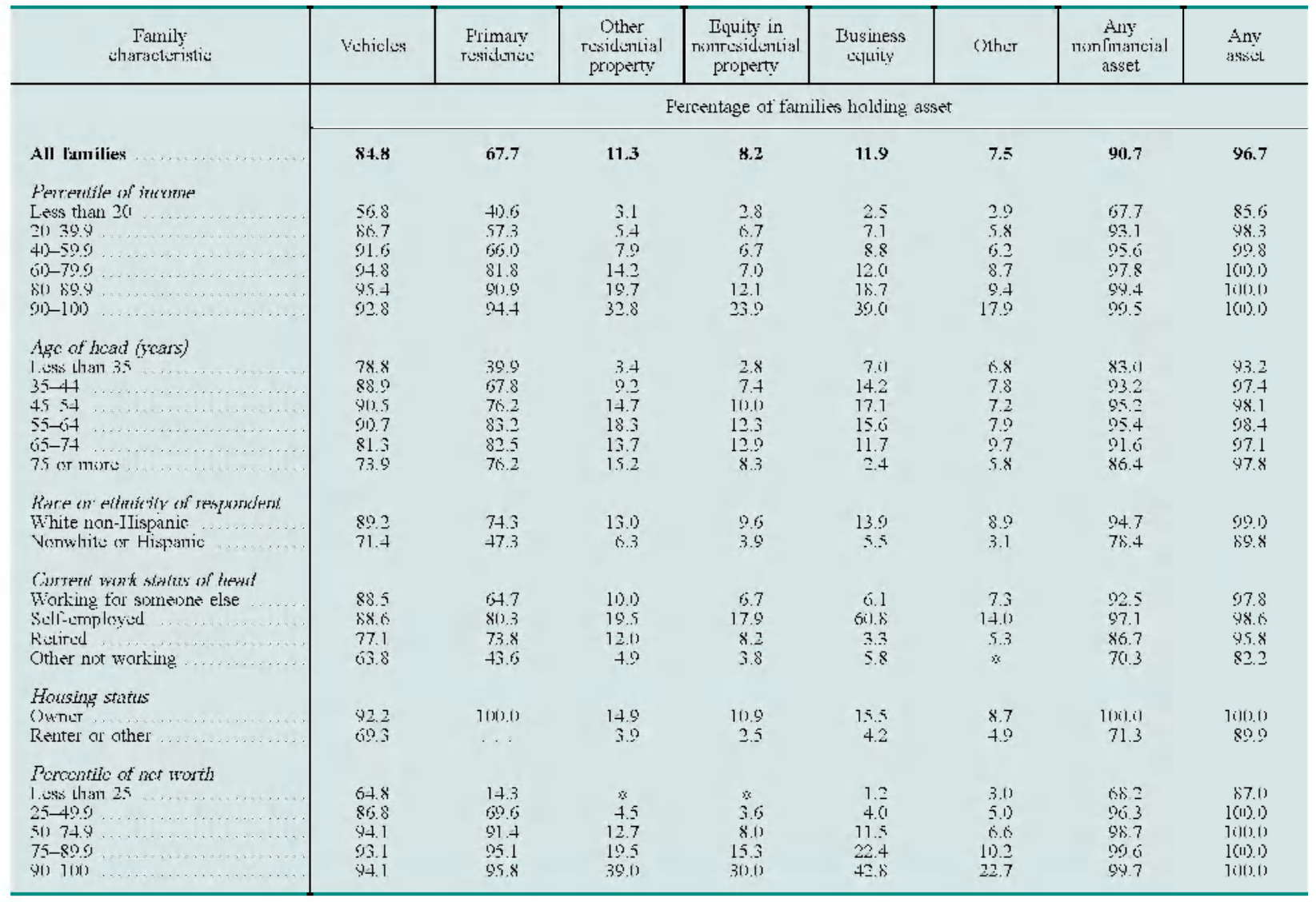

point drop in the share of financial assets from 2001 to 2004 discussed earlier in this article (table 4). The changes in these shares may have been driven by changes in portfolio choices, portfolio valuation, or both. Over the six most recent surveys, the 2001 estimate of the value of nonfinancial assets as a share of total assets, 58.0 percent, appears to be the low point; the 2004 level, 64.3 percent, is about the same as the level seen in the 1995 survey (table 7). Over the recent three-year period, the value of primary residences as a share of nonfinancial assets increased 3.4 percentage points, to 50.3 percent, the largest share ever recorded in the survey. The share of other residential property also rose. The largest offsetting decline was in the share of business equity, which fell 3.4 percentage points. Smaller declines were seen in the shares of the remaining nonfinancial assets.

In 2004, the level of ownership of nonfinancial assets was 92.5 percent, 1.8 percentage points higher than in 2001 (first half of tables 8.A and 8.B, next-tolast column). Across most of the demographic groups shown, the 2004 rate was about 90 percent or moreexceptions were the lowest income and wealth groups, nonwhite or Hispanic families, families headed by persons who were neither working nor retired, and renters. Over the 2001-04 period, ownership rose most for the lowest income and wealth groups, the youngest and the two oldest age groups, nonwhite or Hispanic families, renters, and families headed by persons who were neither working nor retired. The only substantial declines in ownership were seen by the 55-64 age group and the second quintile of the income distribution.

Over the recent period, the median holding of nonfinancial assets for families having any such assets rose 22.2 percent, and the mean rose 19.5 percent. Across demographic groups, substantial gains far outnumbered declines in the median. Over this time, the median fell only for some groups that saw gains in ownership; this result suggests that the fall in the median may have been driven, at least in part, by the influx of new owners with relatively small holdings. 
8. Continued

A. 2001 Survey of Consumer Finances-Continued

\begin{tabular}{|c|c|c|c|c|c|c|c|c|}
\hline $\begin{array}{l}\text { Family } \\
\text { characteristic }\end{array}$ & Vehicles: & $\begin{array}{l}\text { F'rimary } \\
\text { rusidences }\end{array}$ & $\begin{array}{l}\text { Other } \\
\text { residential } \\
\text { property }\end{array}$ & $\begin{array}{l}\text { Equity in } \\
\text { nomrosidemtial } \\
\text { property }\end{array}$ & $\begin{array}{l}\text { Dusiness } \\
\text { เejuily }\end{array}$ & ()het & $\begin{array}{l}\text { Any } \\
\text { mionfinancial } \\
\text { asset }\end{array}$ & $\begin{array}{l}\text { Any } \\
\text { ansito }\end{array}$ \\
\hline & \multicolumn{8}{|c|}{ Metian value of holdings for tamilies holding asset (thousands of $2(11) 4$ dollars) } \\
\hline All limilies & 14.4 & 131.0 & 85.2 & 52.7 & 106.5 & 12.8 & 120.9 & 1568 \\
\hline 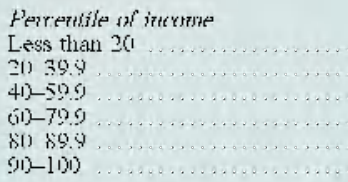 & $\begin{array}{r}5.7 \\
8.9 \\
13.4 \\
18.7 \\
24.2 \\
31.9\end{array}$ & $\begin{array}{r}610.2 \\
85.2 \\
1191.2 \\
138.5 \\
186.4 \\
310.5\end{array}$ & $\begin{array}{r}26.6 \\
76.9 \\
53.3 \\
74.6 \\
66.6 \\
213.0\end{array}$ & $\begin{array}{r}34.6 \\
32.11 \\
32.01 \\
53.3 \\
49.11 \\
155.8\end{array}$ & $\begin{array}{r}6(1.1) \\
37.3 \\
655.7 \\
66.65 \\
106.5 \\
285.7\end{array}$ & $\begin{array}{r}6.4 \\
6.4 \\
11) .7 \\
11) .7 \\
21.3 \\
53.3\end{array}$ & $\begin{array}{r}36.5 \\
601.7 \\
08.2 \\
161.5 \\
230.2 \\
510.8\end{array}$ & $\begin{array}{r}24.4 \\
71.5 \\
122.5 \\
245.1 \\
401.6 \\
1,1075.1\end{array}$ \\
\hline 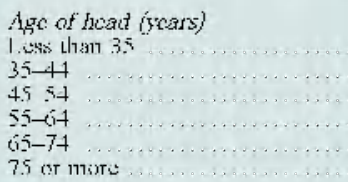 & $\begin{array}{r}12.1 \\
15.8 \\
16.7 \\
16.1 \\
14.5 \\
9.4\end{array}$ & $\begin{array}{l}1101.2 \\
133.1 \\
143.8 \\
138.5 \\
137.4 \\
118.2\end{array}$ & $\begin{array}{r}79.4 \\
75.5 \\
69.2 \\
85.2 \\
154.4 \\
85.2\end{array}$ & $\begin{array}{l}35.5 \\
42.1 \\
6 i 1.3 \\
83.6 \\
53.3 \\
29.8\end{array}$ & $\begin{array}{r}53.3 \\
1106.5 \\
110.6 \\
106.5 \\
1106.5 \\
544.2\end{array}$ & $\begin{array}{r}10.7 \\
9.6 \\
11.7 \\
32.1 \\
21.3 \\
12.8\end{array}$ & $\begin{array}{r}31.7 \\
125.5 \\
1.5 i 1.8 \\
157.5 \\
158.5 \\
1.31 .6\end{array}$ & $\begin{array}{r}41.4 \\
167.5 \\
225.7 \\
241.1 \\
228.6 \\
1811.6\end{array}$ \\
\hline 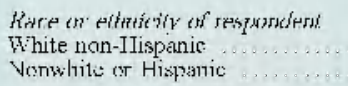 & $\begin{array}{l}15.6 \\
1066\end{array}$ & $\begin{array}{r}138.5 \\
99.1\end{array}$ & $\begin{array}{l}85.2 \\
63.9\end{array}$ & $\begin{array}{l}53.3 \\
32 . i 1\end{array}$ & $\begin{array}{r}11) 6.5 \\
53.3\end{array}$ & $\begin{array}{r}16.1) \\
4.8\end{array}$ & $\begin{array}{r}141.4 \\
62.8\end{array}$ & $\begin{array}{r}197.7 \\
61.3\end{array}$ \\
\hline 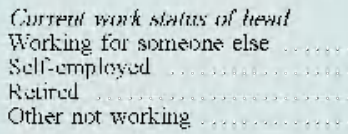 & $\begin{array}{l}14.6 \\
20.5 \\
10.7 \\
110.9\end{array}$ & $\begin{array}{l}127.8 \\
213.13 \\
106.5 \\
1106.5\end{array}$ & $\begin{array}{r}74.6 \\
150.8 \\
91.5 \\
117.2\end{array}$ & $\begin{array}{r}42.1 \\
110.1 \\
61.8 \\
35.1\end{array}$ & $\begin{array}{r}53.3 \\
1+11.9 \\
60.8 \\
117.2\end{array}$ & $\begin{array}{c}11) .7 \\
32.13 \\
21.3 \\
x\end{array}$ & $\begin{array}{l}1108.6 \\
3.56 .8 \\
111.9 \\
806\end{array}$ & $\begin{array}{r}137.4 \\
467.8 \\
145.5 \\
45.5\end{array}$ \\
\hline $\begin{array}{l}\text { Housing status } \\
\text { Ounut } \\
\text { Renter or other }\end{array}$ & $\begin{array}{r}17.2 \\
8.1\end{array}$ & $\begin{array}{c}131.0 \\
\ldots\end{array}$ & 8.2 & $\begin{array}{l}53.3 \\
34.6\end{array}$ & $\begin{array}{r}114.7 \\
37.3\end{array}$ & $\begin{array}{r}16.0 \\
6.4\end{array}$ & $\begin{array}{r}167.2 \\
5.4\end{array}$ & $\begin{array}{r}2.5 .58 \\
14.2\end{array}$ \\
\hline 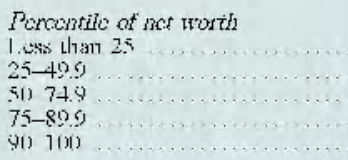 & $\begin{array}{r}6.7 \\
13.5 \\
16.2 \\
219.2 \\
30.7\end{array}$ & $\begin{array}{r}52.7 \\
74.6 \\
127.8 \\
213.15 \\
372.8\end{array}$ & $\begin{array}{r}8 \\
25.6 \\
53.3 \\
85.2 \\
233.7\end{array}$ & $\begin{array}{r}56 \\
5.6 \\
26.6 \\
55.7 \\
235.5\end{array}$ & $\begin{array}{r}1(1.7 \\
16.1) \\
53.3 \\
127.8 \\
532.6\end{array}$ & $\begin{array}{l}4.3 \\
11) .7 \\
10.7 \\
10.2 \\
42.6\end{array}$ & $\begin{array}{r}8.8 \\
66.7 \\
1.54 .3 \\
31)(1.1 \\
758.9\end{array}$ & $\begin{array}{r}8.7 \\
79.5 \\
279.7 \\
541.6 \\
1.531 .7\end{array}$ \\
\hline $\begin{array}{l}\text { MFwo } \\
\text { Mean value of holdings fior } \\
\text { familius holding issot }\end{array}$ & 19.5 & 192.6 & $19 \$ .4$ & 277.2 & 687.5 & 60.2 & 306.6 & 495.6 \\
\hline
\end{tabular}

\section{Vehicles}

Vehicles continue to be the most commonly held nonfinancial asset. ${ }^{26}$ Over the recent three-year period, the share of families that owned some type of vehicle rose 1.5 percentage points, to 86.3 percent. Ownership rose for most demographic groups but particularly for families in the lowest income and wealth groups, families headed by persons aged 65 to 74, and nonwhite or Hispanic families.

The median market value of vehicles for those who owned at least one declined 1.4 percent from 2001 to

26. The definition of velhicles here is a broad one that incluctes cars. vans, sport-utility wehicles, trucks, motor homes, recreational vehicles. motoreyeles, boats, airplanes. and helicopters. Of fanilics owning any type of folnicle in 2004. 99.8 pereent had a car. vall, sportutility vehicle, motorcycle, or truck. The remaining types of vehicle were held by 13.3 percent of families.
2004, while the mean rose 3.1 percent $^{27}$ The median value of vehicle holdings fell notably for the lowest two income and wealth groups, the two oldest and the youngest age groups, nonwhite or Hispanic families, renters, and families having a head who was retired; for most other families, the median rose. Continuing a trend, the share of the total value of owned vehicles attributable to sport-utility vehicles rose over the recent period from 14.0 percent to 19.1 percent (data not shown in the tables).

Some families have vehicles that they lease or that are provided to them by an employer for personal

27. Survey respondents are asked to provide the year, make, and moctel of each of their cars, vans, sport-utility vehicles, and trucks. This information is used to obtain market prises from data collected by the Vational Automobile Dealers issociation and a varicty of other sources. For ollher types of vehicle, the respontent is asked to provicte a best estimate of the current value. 
8. Family holdings of nonfinancial assets and of any asset, by selected characteristics of families and type of asset, 2001 and 2004 surveys Continued

B. 2004 Survey of Consumer Finances

\begin{tabular}{|c|c|c|c|c|c|c|c|c|}
\hline $\begin{array}{l}\text { Family } \\
\text { characteristic }\end{array}$ & Vhicles: & $\begin{array}{l}\text { F'rimary } \\
\text { rusidtenco }\end{array}$ & $\begin{array}{l}\text { Other } \\
\text { residential } \\
\text { property }\end{array}$ & $\begin{array}{l}\text { Equity in } \\
\text { nomresidumtial } \\
\text { property }\end{array}$ & $\begin{array}{l}\text { Dusiness } \\
\text { เéuily }\end{array}$ & ()thet & $\begin{array}{l}\text { Any } \\
\text { minn finamcial } \\
\text { asset }\end{array}$ & $\begin{array}{l}\text { Any } \\
\text { ansith }\end{array}$ \\
\hline & \multicolumn{8}{|c|}{ F'ereentage of families holting asset } \\
\hline All limilies & 86.3 & 69.1 & 12.5 & 8.3 & 11.5 & 7.8 & 92.5 & 97.9 \\
\hline 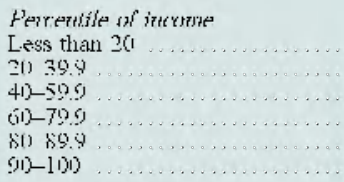 & $\begin{array}{l}65.1) \\
5.5 .3 \\
51.6 \\
55.3 \\
9.5 .9 \\
5.1\end{array}$ & $\begin{array}{l}41.3 \\
57.0 \\
71.5 \\
83.1 \\
91.8 \\
94.7\end{array}$ & $\begin{array}{r}3.6 \\
6.9 \\
11.19 \\
14.1 \\
19.3 \\
37.2\end{array}$ & $\begin{array}{r}2.7 \\
3.8 \\
7.6 \\
11) .5 \\
12.8 \\
21.8\end{array}$ & $\begin{array}{r}3.7 \\
6.7 \\
5.5 \\
12.1 \\
16.11 \\
34.7\end{array}$ & $\begin{array}{r}3.0 \\
4.4 \\
7.5 \\
11) .4 \\
8.3 \\
16.7\end{array}$ & $\begin{array}{l}76.4 \\
92 . i 1 \\
06.7 \\
28.4 \\
90.1 \\
95.3\end{array}$ & $\begin{array}{r}92.2 \\
97.8 \\
510.8 \\
1(11) .1 \\
99.8 \\
1(11) .1)\end{array}$ \\
\hline 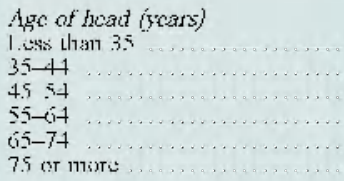 & $\begin{array}{l}\$ 2.9 \\
80.4 \\
88.8 \\
88.6 \\
80.1 \\
78.9\end{array}$ & $\begin{array}{l}41.6 \\
68.3 \\
77.3 \\
70.1 \\
81.3 \\
8.5 .2\end{array}$ & $\begin{array}{r}5.1 \\
9.4 \\
16.3 \\
10.5 \\
10.0 \\
9.7\end{array}$ & $\begin{array}{r}3.3 \\
5.4 \\
11.4 \\
12.8 \\
119.6 \\
7.7\end{array}$ & $\begin{array}{r}6.9 \\
13.9 \\
15.7 \\
15.8 \\
8.0 \\
5.3\end{array}$ & $\begin{array}{l}5.5 \\
6.1 \\
9.7 \\
0.2 \\
0.1) \\
8.5\end{array}$ & $\begin{array}{l}88.6 \\
93.1 \\
94.7 \\
92.6 \\
95.6 \\
92.5\end{array}$ & $\begin{array}{l}96.5 \\
67.7 \\
98.3 \\
67.5 \\
69.5 \\
99.6\end{array}$ \\
\hline 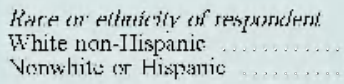 & $\begin{array}{l}\text { (11). } 3 \\
76.1\end{array}$ & $\begin{array}{l}76.1 \\
50.8\end{array}$ & $\begin{array}{r}14.1) \\
\times .9\end{array}$ & $\begin{array}{l}0.2 \\
5.8\end{array}$ & $\begin{array}{r}13.6 \\
5.9\end{array}$ & $\begin{array}{l}9.3 \\
3.8\end{array}$ & $\begin{array}{l}95.8 \\
84 . i 1\end{array}$ & $\begin{array}{l}59.3 \\
94.4\end{array}$ \\
\hline 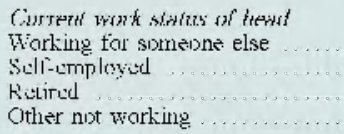 & $\begin{array}{l}80.7 \\
91.2 \\
79.0 \\
6 f 5.9\end{array}$ & $\begin{array}{l}65.5 \\
79.1 \\
75.8 \\
410.1\end{array}$ & $\begin{array}{r}11) .4 \\
2.5 .8 \\
12.8 \\
5.4\end{array}$ & $\begin{array}{r}5.8 \\
18.7 \\
7.9 \\
x\end{array}$ & $\begin{array}{r}5.8 \\
5 \$ .1 \\
3.5 \\
6.5\end{array}$ & $\begin{array}{r}7.1 \\
12.9 \\
7.1 \\
6.4\end{array}$ & $\begin{array}{l}93.8 \\
97.5 \\
89.8 \\
76.3\end{array}$ & $\begin{array}{l}58.4 \\
99.1 \\
97.7 \\
80.6\end{array}$ \\
\hline $\begin{array}{l}\text { Housing status } \\
\text { Ownut } \\
\text { Renter or other }\end{array}$ & $\begin{array}{l}92.3 \\
73.1\end{array}$ & $\begin{array}{c}1000.0 \\
\ldots\end{array}$ & $\begin{array}{r}1.5 .7 \\
5.4\end{array}$ & $\begin{array}{r}11.0 \\
2.4\end{array}$ & $\begin{array}{r}14.7 \\
4.3\end{array}$ & $\begin{array}{l}9.2 \\
4.5\end{array}$ & $\begin{array}{r}10 i 1 . i 1 \\
75.5\end{array}$ & $\begin{array}{r}\text { 1i10.0 } \\
53.3\end{array}$ \\
\hline 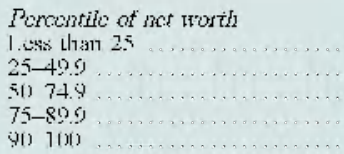 & $\begin{array}{l}69.8 \\
80.2 \\
92.11 \\
55.2 \\
93.1\end{array}$ & $\begin{array}{l}1.5 .2 \\
71.2 \\
93.4 \\
96.2 \\
96.9\end{array}$ & $\begin{array}{r}8 \\
4.2 \\
12.7 \\
23.1 \\
4.5 .6\end{array}$ & $\begin{array}{r}3 \\
4.1 \\
8.3 \\
15.1 \\
28.8\end{array}$ & $\begin{array}{l}* \\
5.6 \\
11.2 \\
15.5 \\
41.8\end{array}$ & $\begin{array}{r}2.9 \\
5.4 \\
7.8 \\
12.3 \\
18.8\end{array}$ & $\begin{array}{l}73.7 \\
97.5 \\
94.11 \\
90.8 \\
90.9\end{array}$ & $\begin{array}{r}91.7 \\
1(11) .1) \\
1(10.1) \\
1(11) .1) \\
1(10.10\end{array}$ \\
\hline
\end{tabular}

use. The share of families having a vehicle from any source rose 1.3 percentage points over the recent period, to 89.2 percent (data not shown in the tables). The small difference between this rate and the ownership rate for personally owned vehicles belies a larger change in the rates of holding for leased and employer-provided vehicles. The proportion of families with a leased vehicle fell from 5.8 percent to 4.0 percent, while that with an employer-provided vehicle fell from 9.1 percent to 7.7 percent.

\section{Primary Residence and Other Residential Real Estate}

The homeownership rate over the 2001-04 period continued its upward trend, rising 1.4 percentage points, to 69.1 percent ${ }^{28}$ In 2004 , groups that had a

28. This measure of prinary residences conprises mobile homess and their sites. the parts of farms and ranches not used for a farming or ranching business, conclominiums, cooperalives, townhouses, other single-lamily homes, and other permanent dwellings. rate less than the overall rate included nonwhite or Hispanic families, families whose head was neither working nor retired, families with relatively low income or wealth, and families headed by persons aged less than 35. Over the three-year period, ownership rose most for families in the middle of the income and wealth distributions, for families headed by persons aged 75 or older, and for nonwhite or Hispanic families; the rate fell notably for the 55-64 age group and for the self-employed and the othernot-working work-status groups. Despite the aboveaverage rise in ownership for nonwhite or Hispanic families, their ownership rate remained well below that for other families.

As would be expected from the large increase in both the share of total assets attributable to nonfinancial assets and the share of nonfinancial assets attributable to primary residences, the median and mean values of the primary residences of homeowners rose sharply over the recent period; overall, the median rose 22.1 percent, and the mean rose 28.1 percent. Because housing wealth is typically the largest com- 
8.- Continued

B. 2004 Survey of Consumer Finances-Continued

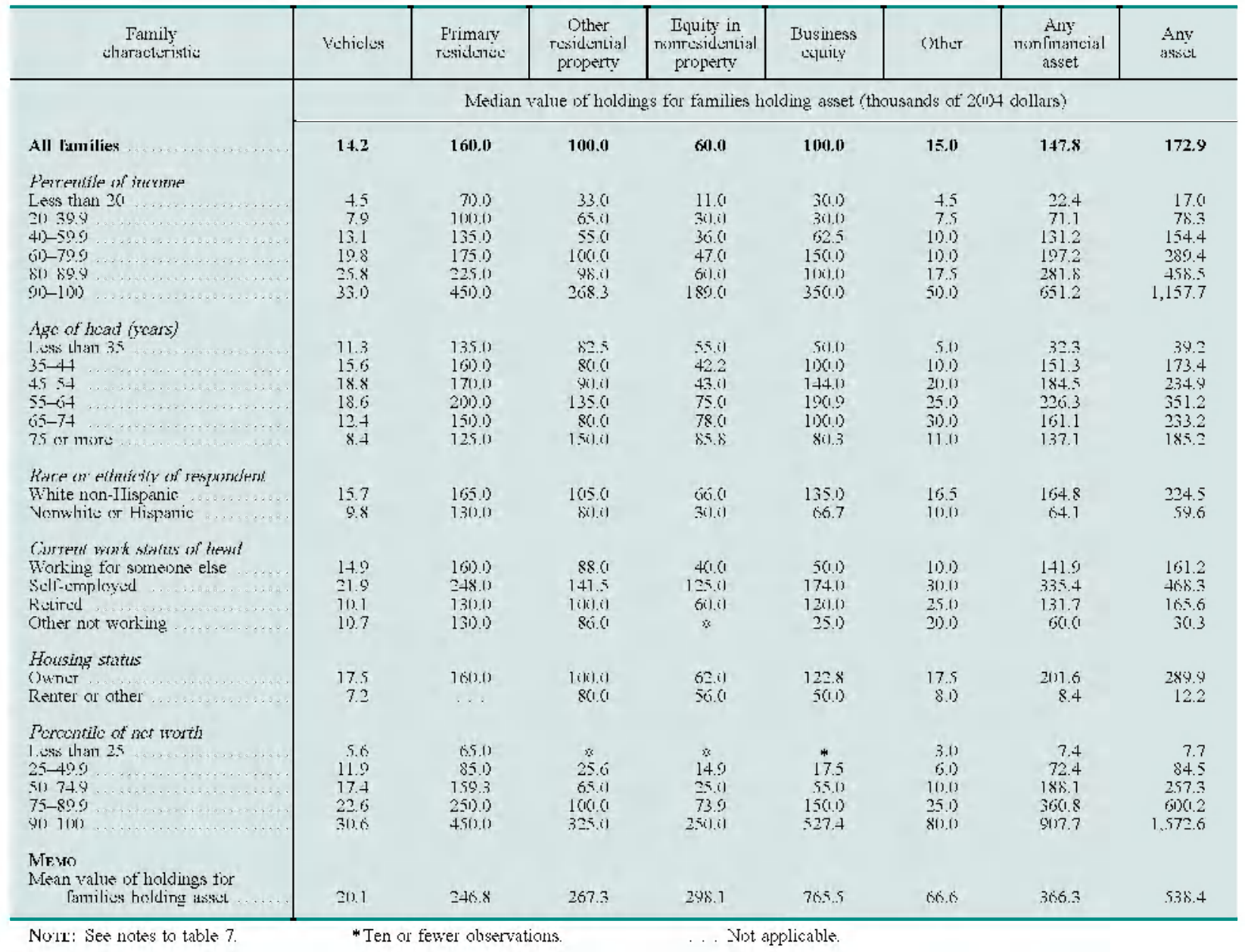

ponent of families' fungible wealth, the large percentage gains in the median and mean produced large dollar gains: $\$ 29,000$ for the median and $\$ 54,200$ for the mean. Homeowners in all demographic groups saw gains in the median, most of them substantial. One of the largest increases was the 31.2 percent rise in the median value of primary residences for nonwhite or Hispanic families; in contrast, the median for other families rose 19.1 percent.

In 2004, 12.5 percent of families owned some form of residential real estate besides a primary residence (second homes, time shares, one- to four-family rental properties, and other types of residential property), a level up 1.2 percentage points from the figure in 2001 but approximately the same as the 1998 estimate. Ownership is much more common among the highest income and wealth groups, among the age groups between 45 and 74, and among families headed by self-employed persons. As was the case with primary residences, the median and mean values for owners increased sharply over the recent period; the median rose 17.4 percent and the mean 34.7 percent. Most of the demographic groups saw substantial gains in the median; only a few saw declines, but where they occurred they tended to be substantial.

\section{Net Equity in Nonresidential Real Estate}

The ownership of nonresidential real estate was about unchanged at 8.3 percent of families in $2004^{29}$ Ownership follows approximately the same relative distribution over demographic groups as does the owner-

29. - Vonresidential real estate comprises the following types of property unless it is owned through a business: conmercial property, rental property with five or more units, larm and ranch land, unclevelopect lanct, and all other types of nonresidential real estate. 
ship of other residential real estate. Changes in ownership during the recent period were mixed across demographic groups. Among the income groups with substantial ownership in 2001, the key changes were a decline in ownership among the highest decile and an increase among the fourth quintile. Overall, the median value of such property for owners rose 13.9 percent, and the mean rose 7.5 percent. Among income groups, the largest gains in the median were in the top two deciles, which also had the highest rates of ownership; declines in the median appeared for all other income groups except the third quintile.

\section{Net Equity in Privately Held Businesses}

The share of families that owned a privately held business interest edged down 0.4 percentage point during the recent period, to 11.5 percent ${ }^{30}$ The proportion has changed little over the past several surveys. Ownership of this type of asset tends to increase with income and wealth and to be the highest for families headed by persons aged between 45 and 64; over the recent three-year period, declines in ownership were largely concentrated in the highest income and wealth groups. Continuing a pattern seen in the preceding three years, ownership also declined among families with a head who was selfemployed .1 $^{31}$

The median holding of business equity for those having any declined 6.1 percent, while the mean increased 11.3 percent. These changes follow a jump of 53.0 percent in the median and 21.8 percent in the mean between the 1998 and 2001 surveys. Across income groups over the recent three-year period, gains in the median were seen in the top decile and the fourth quintile. Growth rates in median holdings were similar across racial or ethnic groups; however, the median level for nonwhites or Hispanics remained roughly half that of other families with business assets.

30. The forns of business in this category are sole proprictorships, limited partnerships. other types of partnership. subchapter $\mathbf{S}$ corporations and other types of corporation that are not publicly traded. limited liability companies. and other types of private business. If the fanily surveyed lived on a farm or ranch that was used at lcast in part for agricultural business, the value of that part net of the corresponting share of associated debts is included with other business assels

31. In the survey: self-enployment status and business ownership are independently detemined. Among the 11.5 pereent of tamilies with a business in 2004, 69.9 pereent hat a family heat or the spouse or partner of the head who was self-einployed; anong the 15.0 pereent of families in which either the lead or the spouse or partner of the head was self-employed, 53.5 percent ouned a business (dala not shown in the tables?
The SCF classifies privately owned business interests into those in which the family has an active management role and those in which it does not. Of families having any business interests in 2004, 92.8 percent had an active role and 12.3 percent had a passive role; 5.1 percent had interests in which they had each type of role (data not shown in the tables). In terms of assets, the actively managed interests accounted for 89.1 percent of total privately owned business interests. The median number of actively managed businesses was 1 . The businesses reported in the survey were a mixture of very small businesses with moderate values and substantially more valuable businesses.

Families with more than one business are asked to report which business is most important; that business is designated as the primary one. ${ }^{32}$ The vast majority of primary businesses operated in an industry other than manufacturing; the most common organizational form of those businesses was sole proprietorship, and the median number of employees was 2 . However, primary actively managed businesses with more than two employees accounted for 83.7 percent of the value of all such businesses, and the largest share of value (40.6 percent) was attributable to businesses organized as subchapter $\mathrm{S}$ corporations.

\section{Other Nonfinancial Assets}

Ownership of the remaining nonfinancial assets (tangible items including artwork, jewelry, precious metals, antiques, hobby equipment, and collectibles) increased marginally in the recent period, to 7.8 percent. Among wealth groups, the notable change was a decline of 3.9 percentage points in ownership in the highest wealth group; this change entirely offset a gain for the group over the previous three years. For families having such assets, the median value rose 17.2 percent over the recent period, and the mean rose 10.6 percent. Across wealth groups, median holdings rose substantially in the top two wealth groups and declined among the rest.

\section{Unrealized Capital Gains}

Changes in the values of assets such as stock, real estate, and businesses are a key determinant of changes in families' net worth. Unrealized gains are

32. lior families with only one business. that business is. by default, considered the primary one. In 2004. the prinary actively nanaged business accounted for 78.7 percent of the value of all actively managed businesses. 
9. Family holdings of unrealized capital gains, by selected characteristics of families, 1995-2004 surveys Thousands of 2004 dollars

\begin{tabular}{|c|c|c|c|c|c|c|c|c|}
\hline \multirow{2}{*}{$\begin{array}{c}\text { Tramily } \\
\text { chidriaturistic }\end{array}$} & \multicolumn{2}{|c|}{1905} & \multicolumn{2}{|c|}{1 1) } & \multicolumn{2}{|c|}{$20 i 11$} & \multicolumn{2}{|c|}{20114} \\
\hline & Mitian & MLam & Mecilian & VL:an & Vecitian & ML:an & Mocitian & Maㅛ \\
\hline All limilies & 6.8 & 83.3 & 12.5 & 111.9 & 16.0 & 138.2 & 23.0 & 161.7 \\
\hline 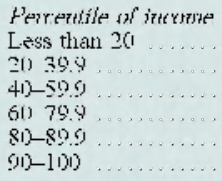 & $\begin{array}{c}1 \\
4 \\
4.6 \\
16.4 \\
33.2 \\
80.0\end{array}$ & $\begin{array}{r}10.1 \\
31.2 \\
41.4 \\
56.9 \\
85.5 \\
452.5\end{array}$ & $\begin{array}{r}1 \\
2.1 \\
10.4 \\
23.4 \\
39.6 \\
112.5\end{array}$ & $\begin{array}{r}2(1.5) \\
34.1 \\
51.1 \\
76.3 \\
110.5 \\
643.7\end{array}$ & $\begin{array}{c}1 \\
1.5 \\
10.1 \\
20.8 \\
58.6 \\
170.4\end{array}$ & $\begin{array}{r}18.6 \\
4.0 \\
49.1 \\
91.8 \\
151.1 \\
824.1\end{array}$ & $\begin{array}{c}* \\
3 . i 1 \\
21.0 \\
46.7 \\
7(1.0 \\
221.5\end{array}$ & $\begin{array}{r}31.1 \\
52.1 \\
74.3 \\
120.3 \\
155.5 \\
0105.8\end{array}$ \\
\hline 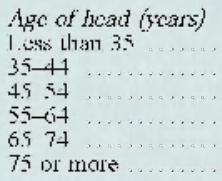 & $\begin{array}{c}t \\
4.9 \\
22.9 \\
34.01 \\
36.9 \\
4(1.2\end{array}$ & $\begin{array}{r}11.8 \\
44.7 \\
117.7 \\
1619.5 \\
145.3 \\
1(165.1)\end{array}$ & $\begin{array}{c}\dagger \\
8.2 \\
2.5 .9 \\
40.8 \\
53.9 \\
41.7\end{array}$ & $\begin{array}{r}17.9 \\
73.4 \\
145 . i 1 \\
216.8 \\
161.2 \\
131.8\end{array}$ & $\begin{array}{c}\dagger \\
11.7 \\
29.8 \\
43.6 \\
51.1 \\
53.3\end{array}$ & $\begin{array}{r}30.3 \\
50.1) \\
164.5 \\
237.2 \\
254.9 \\
150.8\end{array}$ & $\begin{array}{c}\div \\
19.4 \\
39.11 \\
58.1 \\
5 i 1 . i 1 \\
58.1\end{array}$ & $\begin{array}{r}28.1 \\
115.5 \\
205.4 \\
286.7 \\
231.4 \\
185.0\end{array}$ \\
\hline
\end{tabular}

Note: See note to table 1

"L.ess than $1.05(850)$.

increases or decreases in the value of assets that are yet to be sold. To obtain information on this part of net worth, the survey asks about changes in value from the time of purchase for certain key assetspublicly traded stocks, pooled investment funds, the primary residence, other real estate, and the current tax basis of businesses. ${ }^{33}$ The median unrealized capital gain in these assets over the 2001-04 period moved up 43.8 percent, and the mean moved up 17.0 percent (table 9); during the 1998-2001 period, the median had risen 28.0 percent, and the mean had risen 23.5 percent. The recent gains predominantly accrued to the middle income groups and to age groups other than the youngest and the 65-74 groups. The rise in unrealized gains reflects strong appreciation of residential real estate over the period as well as the relative illiquidity of real estate and businesses. Of the total amount of unrealized capital gains in $2004,44.6$ percent was due to appreciation of primary residences; the comparable figure for 2001 had been 35.6 percent (data not shown in the tables). In 2004, unrealized gains measured in the SCF accounted for 30.7 percent of the assets of all families; the median share of such gains relative to assets over all families was 11.2 percent.

\section{LIABILITIES}

Liabilities and assets increased substantially from 2001 to 2004, but the rise in liabilities was more rapid overall. Over this time, the principal changes in

33. The survey does not collest information on capital gains on every assel lor which such gains are possible. Mosi notably, it does not collect such informalion for retirement accounts.
10. Amount of debt of all families, distributed by type of debt, 1995-2004 surveys

Pereent

\begin{tabular}{|c|c|c|c|c|}
\hline Type of debt & 1555 & 1958 & $21)(11$ & 20104 \\
\hline \multicolumn{5}{|l|}{ Secured by rasidential property } \\
\hline Primaly residence ........... & 73.1 & 71.4 & 75.2 & 75.2 \\
\hline (Mhus . . . . . . . . . . . . & 7.6 & 7.5 & 6.2 & $8 . .5$ \\
\hline Lines of credit not secured by & & & & \\
\hline $\begin{array}{l}\text { residintial propurty . . . . . } \\
\text { Installment loans }\end{array}$ & $12.1)$ & 13.1 & 12.3 & 11.7 \\
\hline Credit card balances .......... & 3.0 & 3.5 & 3.4 & 3.1) \\
\hline OLhet . . . . . . . . . . . . . . & 2.9 & 3.7 & 2.3 & 1.6 \\
\hline '|istial & $1(10)$ & lilil & $10 i]$ & $100 i$ \\
\hline \multicolumn{5}{|l|}{ MFMMO } \\
\hline $\begin{array}{l}\text { Delit as a prercentage } \\
\text { iol tital is:sicts... }\end{array}$ & 14.6 & 14.2 & 12.1 & 1.5 .1 \\
\hline
\end{tabular}

Note: See note to table 1 and text note 38

different types of debt as a share of total debt were an increase in the share of loans for other residential property and a decrease in the share of installment loans (table 10). The largest share of total debt was debt secured by the primary residence, the amount of which kept pace with the increase in total debt.

Because liabilities increased faster than assets, the ratio of the overall sum of family debts to the sum of their assets (the leverage ratio) rose 2.9 percentage points, from 12.1 percent to 15.0 percent (table 10 , memo line). ${ }^{34}$ This increase follows a 2.1 percentage point decrease over the preceding three years. If the calculation is restricted to families that had debt, the leverage ratio was 19.9 percent in 2004 , an increase of 3.4 percentage points from 2001 (data not shown in the tables).

34. Data from the flow of funds accounts show that the lewerage ratio for the household sector increased from 16.3 percent in 2001 to 18.1 percent in 2004 
11. Family holdings of debt, by selected characteristics of families and type of debt, 2001 and 2004 surveys A. 2001 Survey of Consumer Finances

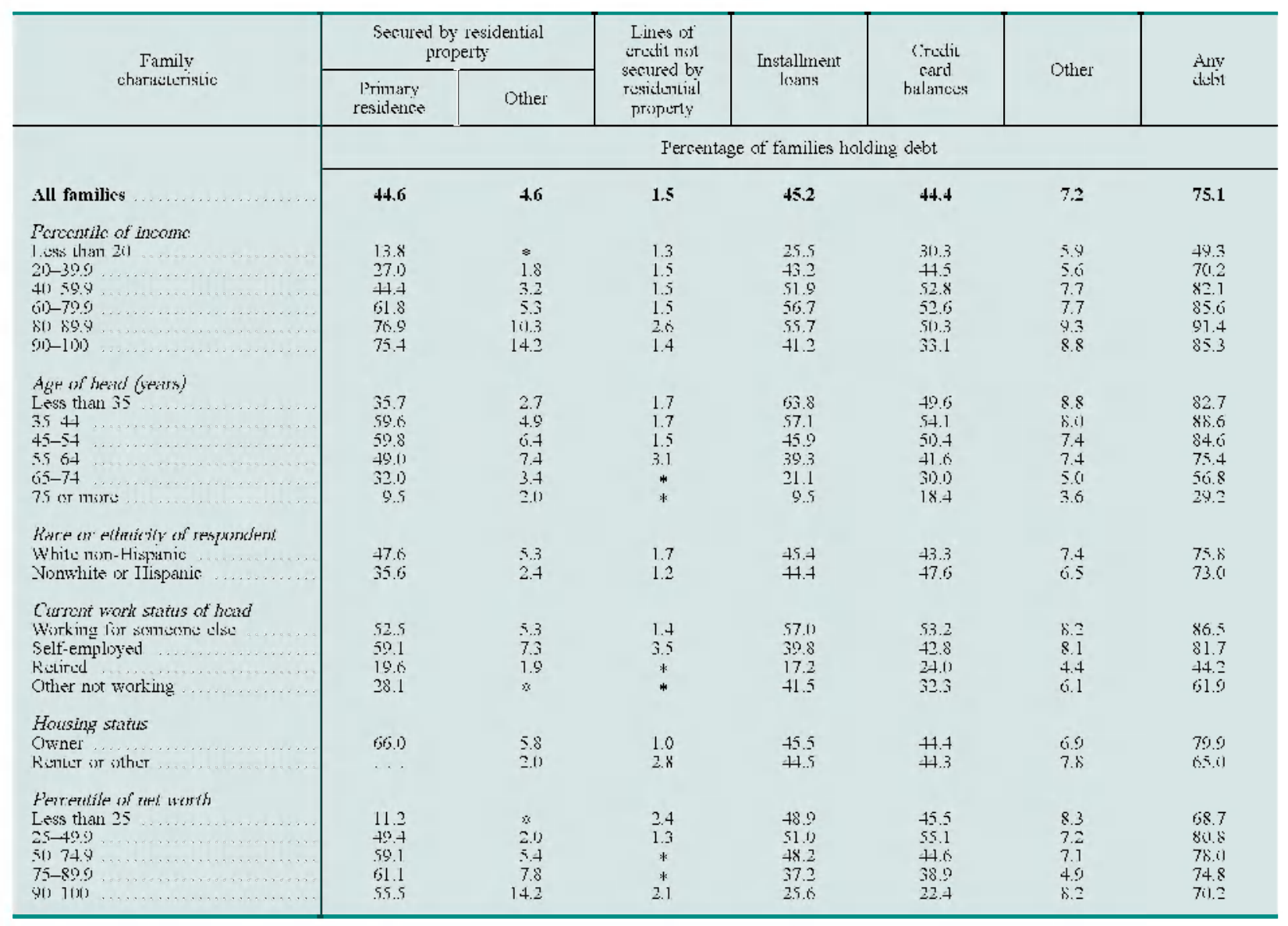

\section{Holdings of Debt}

The share of families with any type of debt climbed 1.3 percentage points during $2001-04$, to 76.4 percent (first half of tables 11.A and 11.B, last column); the share had risen 1.0 percentage point over the preceding three years. Borrowing is less prevalent among families in the lowest income and wealth groups and in age groups 65 or older. Over the 2001-04 period, the prevalence of borrowing declined for renters, the youngest age group, and the lowest quartile of the wealth distribution and increased or held about steady for the other groups. The largest increase was the 11.1 percentage point rise for families headed by persons aged 75 or older.

The overall median and mean values of total outstanding debt for families that had any each rose 33.9 percent from 2001 to 2004; from 1998 to 2001, median debt had increased 9.5 percent and the mean 5.2 percent. Across demographic groups, median debt tends to rise with income and wealth and to rise and then decline with age. The decline among older age groups is driven in large part by the paying off of mortgages on primary residences. Over the recent three-year period, the median amount of outstanding debt rose for all groups except for families headed by persons who were neither working nor retired. The increases in the median were particularly notable for families headed by persons aged 65 or older, but their median remained much below the overall median.

\section{Mortgages and Other Borrowing on the Primary Residence}

Continuing an earlier trend of increases, the proportion of families with debt secured by the primary residence (hereafter, home-secured debt) rose 3.3 percentage points, to 47.9 percent (the share of homeowners with such debt in 2004 was 69.3 percent). ${ }^{35}$

35. Ilone-secured debt sonsists of first-licn and junior-lisn mortgages and home ecuity lines of credil secured by the primary residence. For purposes of this article, first- and junior-lien morigages 
11. Continued

A. 2001 Survey of Consumer Finances - Continued

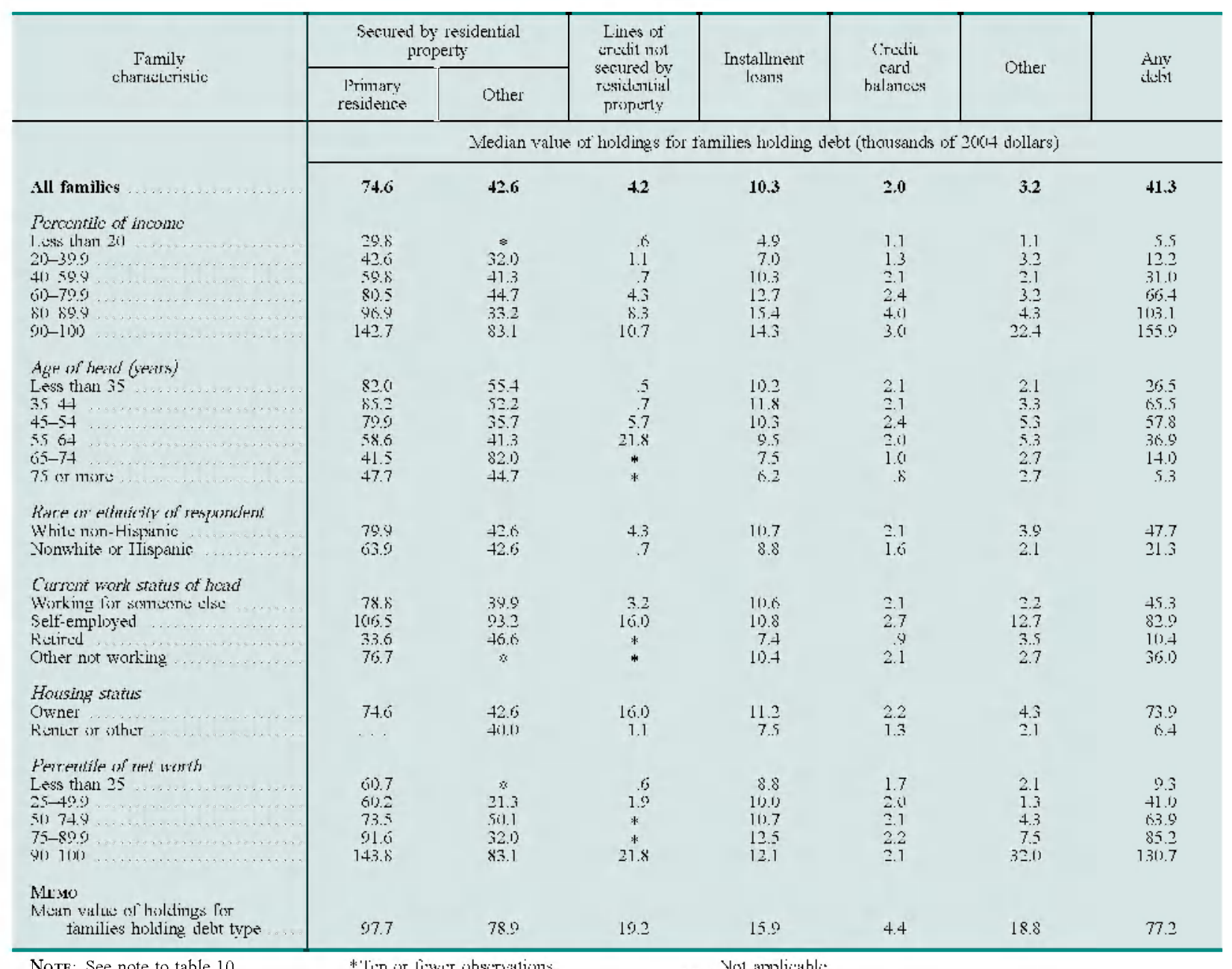

In 2004, 45.0 percent (42.3 percent in 2001) of families had a first-lien mortgage, 4.2 percent $(5.8$ percent in 2001) had a junior-lien mortgage, and 8.6 percent (4.8 percent in 2001) had a home equity line of credit with a current balance (data not shown in the tables). Of the types of debt considered in this article, homesecured debt had the largest change in overall prevalence. The use of such debt tends to rise with income. Across wealth groups, it is more nearly equal for groups above the bottom quartile; however, homeowners in the lowest wealth group in 2004 had the highest rate of such borrowing, 81.6 percent. Over age groups, the rate of borrowing peaks among fami-

consist only of closect-end loans, that is, loans typically with a one-lime extension of credil and a prearranged payment size and frequeney: $A$ s a type of open-end credit, home equity lines typically allow credit sxtensions at the borrower"s discretion subject to a prearranged limit and allow repayments at the borrower's discretion subjest to a prearranged minimun size and frectuency. lies in the 45-54 group and declines sharply among older age groups, a pattern also seen in earlier years. Over the recent period, the prevalence of homesecured debt increased for nearly every demographic group.

Overall, the median amount of home-secured debt rose 27.3 percent from 2001 to 2004 , and the mean rose 27.0 percent; the median had increased 3.8 percent over the preceding three years, and the mean had increased 8.4 percent. In the recent period, median borrowing rose substantially for every group but one. It declined for the 75-or-older age group even as the group had an unusually large increase in the fraction of families having such debt. This result indicates that the decline in the median was driven by a rise in the number of smaller home-secured loans. Overall, in 2004, 91.3 percent (92.4 percent in 2001) of total home-secured debt was owed on first-lien mortgages, 3.0 percent (4.4 percent in 2001) was owed on junior- 
11. Family holdings of debt, by selected characteristics of families and type of debt, 2001 and 2004 surveys - Continued B. 2004 Survey of Consumer Finances

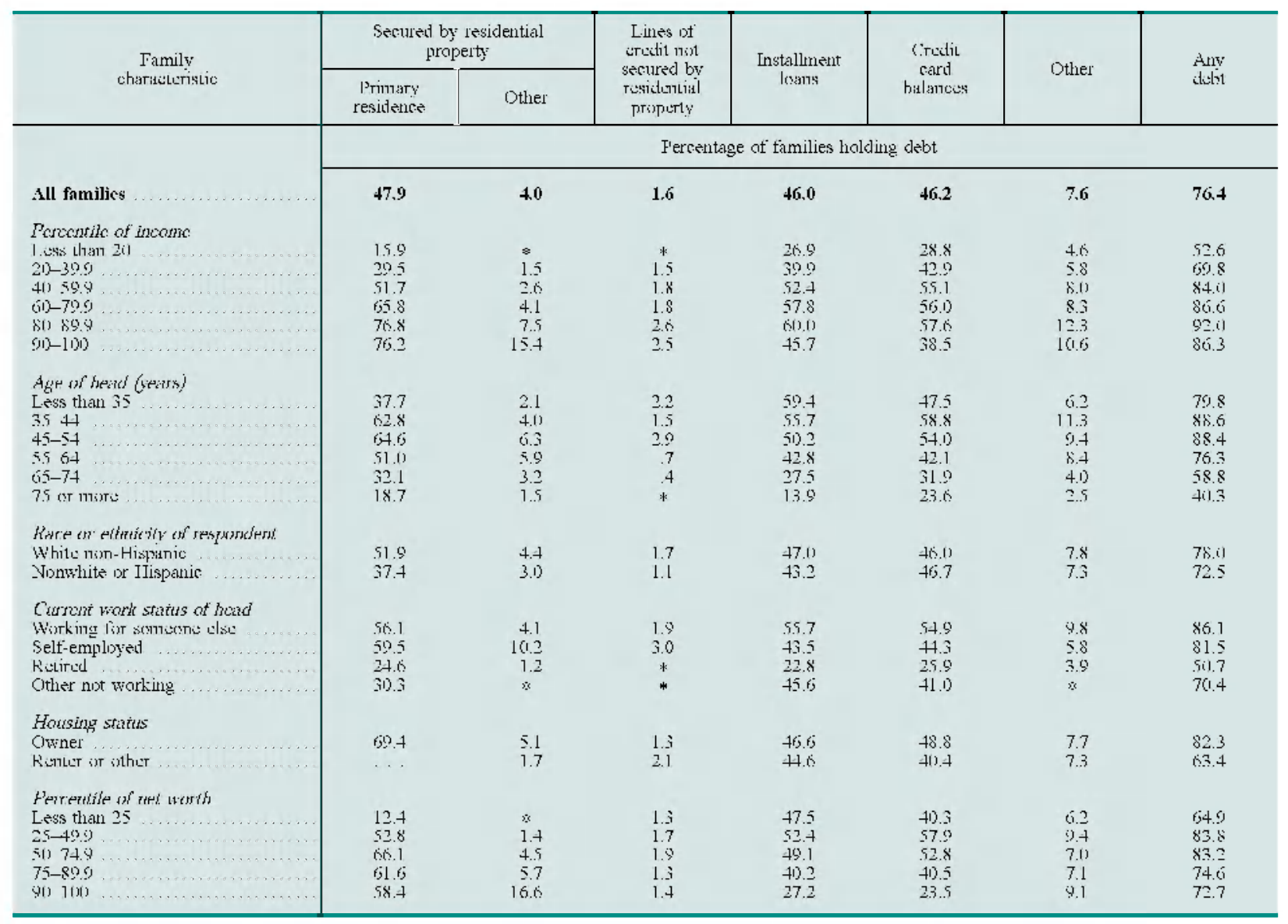

lien mortgages, and 5.7 percent $(3.2$ percent in 2001) was owed on home equity lines of credit (data not shown in the tables).

The rising values of primary residences over the 2001-04 period outpaced the increases in homesecured debt and thus raised the typical amount of home equity held by families. Median home equity among those with home-secured debt rose from $\$ 61,900$ to $\$ 70,000$ over the period, a 13.1 percent increase (data not shown in the tables). ${ }^{36}$ Among those with such debt, the median ratio of homesecured debt to the value of the primary residence held steady at 56.0 percent, down from 58.8 percent in 1998. Over the recent three-year period, an SCFbased estimate of the aggregate ratio of home-secured debt to home values for all homeowners rose 1.4 percentage points, to 34.9 percent.

By eliminating the deductibility of interest payments on most loans other than those on primary and

36. Among all homeowners in 2004 , median home equity was $\$ 86,000$; in 20061 it had been $\$ 74,600$. secondary residences, the Tax Reform Act of 1986 created an incentive for homeowners with a need for additional liquid funds to borrow against their home equity. Over the 2001-04 period, some families may have felt an important additional incentive from low mortgage interest rates, rapidly appreciating home values, and technological changes that reduced the time and cost of mortgage refinancing. Such borrowing against home equity may take the form of refinancing an existing first-lien mortgage for more than the outstanding balance, obtaining a juniorlien mortgage, or accessing a home equity line of credit.

The survey provides detailed information on all these options for home equity borrowing. In 2004, 44.9 percent of homeowners with a first-lien mortgage had refinanced their current first-lien mortgage in the preceding three years (20.8 percent in 2001), and 34.0 percent of such refinancers had borrowed money beyond the amount refinanced (35.2 percent in 2001); the median amount of additional equity extracted by those who had done so was $\$ 20,000$ 
11. Continued

B. 2004 Survey of Consumer Finances-Continued

\begin{tabular}{|c|c|c|c|c|c|c|c|}
\hline \multirow{2}{*}{$\begin{array}{l}\text { Family } \\
\text { charieturistic }\end{array}$} & \multicolumn{2}{|c|}{$\begin{array}{c}\text { Secured by residential } \\
\text { property }\end{array}$} & \multirow{2}{*}{$\begin{array}{l}\text { Lines of } \\
\text { ircedit niwt } \\
\text { secured by } \\
\text { residentiil } \\
\text { priperly }\end{array}$} & \multirow{2}{*}{$\begin{array}{l}\text { Installment } \\
\text { lo:ans: }\end{array}$} & \multirow{2}{*}{$\begin{array}{l}\text { Crectil } \\
\text { cart } \\
\text { bislances }\end{array}$} & \multirow{2}{*}{ Other } & \multirow{2}{*}{$\begin{array}{l}\text { Anv } \\
\text { distit }\end{array}$} \\
\hline & $\begin{array}{l}\text { P'rinnary } \\
\text { resitence }\end{array}$ & Other & & & & & \\
\hline & \multicolumn{7}{|c|}{ Median value of holdings fior tamilies holding tebt (thousands of $20(14$ dollars) } \\
\hline All families $\ldots \ldots \ldots$ & 95.0 & 87.0 & 3.0 & 11.5 & 2.2 & 40 & 55.3 \\
\hline 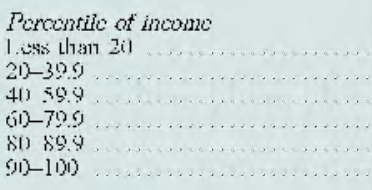 & $\begin{array}{r}37 . i 1 \\
53.3 \\
78 . i 1 \\
57.01 \\
133 . i 1 \\
185.0\end{array}$ & $\begin{array}{r}* \\
32.5 \\
60.11 \\
62.10 \\
78.0 \\
150.10\end{array}$ & $\begin{array}{c}* \\
.3 \\
1.11 \\
7.1) \\
14.0 \\
4(1.1)\end{array}$ & $\begin{array}{r}5.6 \\
8.1) \\
110.8 \\
13.9 \\
1.5 .1 \\
18.1\end{array}$ & $\begin{array}{l}1 . i 1 \\
1.5 \\
2.2 \\
3.01 \\
2.7 \\
4.0\end{array}$ & $\begin{array}{l}2.0 \\
2.7 \\
2.3 \\
3.5 \\
5.0 \\
5.4\end{array}$ & $\begin{array}{r}7.0 \\
16.1 \\
11.7 \\
0.4 \\
136.0 \\
2100.1\end{array}$ \\
\hline 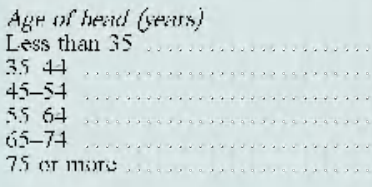 & $\begin{array}{l}107.01 \\
110.01 \\
57.01 \\
83 . i 1 \\
51.01 \\
31 . i 1\end{array}$ & $\begin{array}{r}63.5 \\
75.11 \\
87.1) \\
7118.8 \\
1(11) .1) \\
39.0\end{array}$ & $\begin{array}{c}1.1) \\
1.9 \\
7.10 \\
14.0 \\
4.19 \\
*\end{array}$ & $\begin{array}{r}11.0 \\
12.0 \\
12.19 \\
12.9 \\
8.3 \\
6.7\end{array}$ & $\begin{array}{l}1.5 \\
2.5 \\
2.5 \\
2.2 \\
2.2 \\
1 . i 1\end{array}$ & $\begin{array}{l}3.1) \\
4.10 \\
4.1 \\
5.5 \\
5.10 \\
2.10\end{array}$ & $\begin{array}{l}3.6 .5 \\
87.2 \\
83.2 \\
48.11 \\
25.1 \\
1.5 .4\end{array}$ \\
\hline 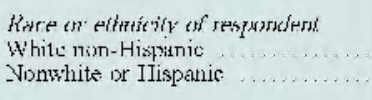 & $\begin{array}{l}98 . i \\
83.01\end{array}$ & $\begin{array}{l}\$ 7.0 \\
6(5.1)\end{array}$ & $\begin{array}{r}4.0 \\
.4\end{array}$ & $\begin{array}{r}12.4 \\
0.5\end{array}$ & $\frac{2.5}{1.6}$ & $\begin{array}{l}4.10 \\
3.1)\end{array}$ & $\begin{array}{l}69.5 \\
310.5\end{array}$ \\
\hline 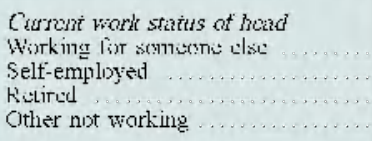 & $\begin{array}{r}1110.0 \\
119.8 \\
42.11 \\
78.1\end{array}$ & $\begin{array}{r}83.13 \\
1(11) .1) \\
79.11 \\
3\end{array}$ & $\begin{array}{l}4.11 \\
2.2 \\
* \\
+\end{array}$ & $\begin{array}{r}12.10 \\
15.4 \\
7.3 \\
7.5\end{array}$ & $\begin{array}{l}2.3 \\
2.7 \\
1.4 \\
2.5\end{array}$ & $\begin{array}{l}3.5 \\
7.1) \\
3.0 \\
\$\end{array}$ & $\begin{array}{l}71.8 \\
93.4 \\
1.5 .4 \\
21.1\end{array}$ \\
\hline $\begin{array}{l}\text { Housing status } \\
\text { Owner } \\
\text { KunLut ar whet }\end{array}$ & 550 & $\begin{array}{l}(11) .1) \\
\$ 3.13\end{array}$ & $\begin{array}{r}8.1) \\
.5\end{array}$ & $\begin{array}{r}12.0 \\
8.7\end{array}$ & $\begin{array}{l}2.5 \\
1.5\end{array}$ & $\begin{array}{l}4.1) \\
3.1\end{array}$ & $\begin{array}{r}95.8 \\
7.8\end{array}$ \\
\hline 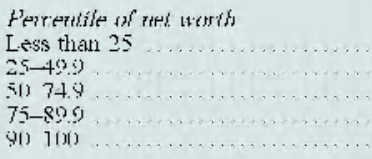 & $\begin{array}{r}71.0 \\
75.0 \\
97.1 \\
115.1 \\
156.1\end{array}$ & $\begin{array}{r}35 \\
25.3 \\
47.0 \\
50.10 \\
148.0\end{array}$ & $\begin{array}{r}.3 \\
1.11 \\
\$ 1.10 \\
22.10 \\
\text { Sil. } 10\end{array}$ & $\begin{array}{r}11.5 \\
9.3 \\
1.3 .3 \\
12.9 \\
17.5\end{array}$ & $\begin{array}{l}1.8 \\
2.01 \\
2.5 \\
3.01 \\
3 . i 1\end{array}$ & $\begin{array}{r}4.11 \\
2.11 \\
4.10 \\
5.10 \\
201.10\end{array}$ & $\begin{array}{r}11.4 \\
+1.2 \\
90.1 \\
111) .7 \\
190.8\end{array}$ \\
\hline 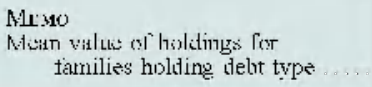 & 124.1 & 166.7 & Sti.ts & 18.8 & 5.1 & 17.1 & 103.4 \\
\hline
\end{tabular}

(data not shown in the tables). ${ }^{37}$ Junior-lien mortgages not used to finance a home purchase were used by 4.7 percent of homeowners in 2004 ( 7.2 percent in 2001), and the median amount owed on such loans for those having one was $\$ 16,000$ ( $\$ 20,200$ in 2001). The proportion of homeowners with home equity lines of credit in 2004 was 17.8 percent (11.2 percent in 2001), and the proportion borrowing against such lines was 12.4 percent (7.1 percent in 2001); the median balance for those borrowing against such lines was $\$ 22,000(\$ 16,000$ in 2001). For 2004 , the major uses of extracted equity were for home improvement and debt consolidation. Home improvement accounted for 45.0 percent of the outstanding

37. Or those with a first-lien morlgage in 2004, 56.7 percent are recorded in the survey as having refinanced it at least ones ( 42.8 persent in 2001): 35.0 perecnt of these refinaneers cxtracted equity in the most recent instance (36.2 percent in 2001), and the median amount extracted was $\$ 20,000$ (clata not shown in the tables). balances attributable to equity extraction, and debt consolidation accounted for 31.0 percent (data not shown in the tables).

With house prices rising over the past three years, much discussion has centered on how families have managed to finance the purchase of a new home. Interest rates are a key determinant of the size of the regular payment that families must make to service their mortgages. The median rate on the stock of outstanding first-lien mortgages on primary residences was 5.90 percent in 2004 (the mean was 6.19) and 7.25 percent in 2001 (the mean was 7.59). Some families select a mortgage with a variable interest rate, typically because such loans have a lower initial rate than a fixed-rate loan. In 2004, 15.0 percent of homeowners with a first-lien mortgage on the primary residence had an interest rate on their loan that could vary; the comparable figure for 2001 was 11.4 percent. 
Another key determinant of mortgage payments is the length of time over which the loan must be repaid. Mortgages with an initial term of thirty years or longer accounted for 57.5 percent of fixed-term first-lien mortgages on the primary residence in 2004 , and those with a term of fifteen years or less accounted for 32.9 percent; in 2001, 62.9 percent had a term of thirty years or more, and 28.6 percent had a term of fifteen years or less. Some purchasers take out mortgages that do not require them to pay back the entire principal over the contract period of the loan; in such cases, a payment of any remaining principal is required at the end of the loan term. In $2004,4.1$ percent of first-lien mortgages on primary residences had such a loan feature; in 2001, the comparable figure had been 2.1 percent.

\section{Borrowing on Other Residential Real Estate}

From 2001 to 2004, the proportion of families that owned other residential property rose, but the proportion with outstanding loans on such properties declined 0.6 percentage point, to 4.0 percent. Only about one-third of owners in 2004 also had a mortgage on the property. As with the ownership of such property, the associated borrowing is most prevalent among families with relatively high income or wealth. Use of such borrowing declined for most demographic groups over the three-year period. But as would be expected from the increased share of total debt attributable to this type of borrowing, the amount outstanding rose substantially. Both the median and the mean amounts owed more than doubled. Median and mean amounts also rose substantially among families with mortgages on other residential real estate in most demographic groups.

\section{Borrowing on Other Lines of Credit}

Only 3.3 percent of families had an available line of credit other than a home equity line in 2004 (data not shown in the tables). ${ }^{38}$ Even fewer families1.6 percent-had a balance on such a line, a proportion virtually unchanged from 2001. The median amount outstanding on these lines fell 28.6 percent over this three-year period, while the mean rose 90.6 percent.

38. In this arlicle, borrowing on lines of credit excluctes borrowing on credil carels.

\section{Installment Borrowing}

Installment borrowing is about as common as homesecured borrowing. ${ }^{39}$ In 2004, 46.0 percent of families had installment debt, an increase of 0.8 percentage point over 2001. Although the use of installment borrowing has increased in each of the past two survey intervals, the overall rate of use is comparable to the levels seen in the 1992 and 1995 surveys. The use of installment borrowing is broadly distributed across demographic groups, with notably lower use only in the lowest income group, the highest wealth group, and families headed by retired persons or persons aged 65 or older. From 2001 to 2004, the median amount owed on installment loans rose 11.7 percent, and the mean rose 18.2 percent. Most of the demographic groups shared in the overall increase in the median. The majority of installment borrowing is related to the purchase of a vehicle (data not shown in the tables); in 2004, such borrowing accounted for 55.5 percent of the total amount owed (54.8 percent in 2001). The second-largest use of installment borrowing is for education-related expenses. Balances on loans for this purpose in 2004 made up 26.0 percent of total installment debt; the comparable figure for 2001 had been 22.2 percent.

\section{Credit Card Balances}

As with installment borrowing, the carrying of credit card balances is widespread but notably lower among the highest and lowest income groups, the highest wealth group, and families headed by persons who are aged 65 or older or are retired. ${ }^{40}$ From 2001 to 2004 , the proportion of families carrying a balance rose 1.8 percentage points, to 46.2 percent. The preceding three years had seen a much smaller increase in use. The recent increase was shared by most demographic groups; the proportion carrying a balance declined for the lowest two income groups, the lowest wealth group, the youngest age group, nonwhite or Hispanic families, and renters.

39. The term "installnewt borrowing" in this article describes closed-end consumer loans, that is, those that typically have fixed payments and a fixed tern. Lixanples are automobile loans. student loans. and loans for furniture, appliances, and other durable goods.

40. In this article, credil card balances consist of balances on bank-type cards (such as Fisa, MasterCard, and Discover, and Oplima and other Anerican lixpress eards that routincly allow earrying a balance), store carcls or charge accounts, gasoline company cards. so-called iravel and entertainment cards (such as American Fixpress cards that do not routinely allow carrying a balanse and Dinces (lub), other credit cards. and rewolving store accounts that are not ticd to a crectil card. Balances exclude purchases made alter the most recent bill was paicl. 
Overall, the median balance for those carrying a balance rose 10.0 percent, to $\$ 2,200$; the mean rose 15.9 percent, to $\$ 5,100$. Over the preceding three years, the median had been little changed, but the mean had fallen 8.3 percent. In the recent period, the median balance rose strongly for most demographic groups; but borrowing declined notably for the lowest and next-to-highest income groups and for the youngest age group.

Many families with credit cards do not carry balances. $^{41}$ Of the 74.9 percent of families with credit cards in 2004 , only 58.0 percent had a balance at the time of the interview; in 2001, 76.2 percent had cards, and 55.4 percent of these families had an outstanding balance on them (data not shown in the tables). The proportion of cardholders who had a bank-type card was unchanged over this three-year period, whereas the proportion of cardholders having most other card types declined, as shown in the following table:

\begin{tabular}{|c|c|c|}
\hline \multirow{2}{*}{$\begin{array}{l}\text { Iype or } \\
\text { credit card }\end{array}$} & \multicolumn{2}{|c|}{ (aardholders holding } \\
\hline & $\begin{array}{c}201014 \\
\text { (percest) }\end{array}$ & $\begin{array}{l}\text { Change } 20101 \text { (14 } \\
\text { (percestlage poimls) }\end{array}$ \\
\hline $\begin{array}{l}\text { Bink } \\
\text { Store } \\
\text { (Jasiline } \\
\text { Travel and entertainment } \\
\text { Miscellanelous ........ }\end{array}$ & $\begin{array}{r}9.5 \\
58.4 \\
17.3 \\
1(1.1) \\
2.5\end{array}$ & $\begin{array}{r}.0 \\
-1 . i \\
-3.8 \\
-3.8 \\
.2\end{array}$ \\
\hline
\end{tabular}

The declines in card ownership probably reflect, at least in part, a rise during the period in the issuance of bank-type cards under the brand names of stores and gasoline companies and in the issuance of new types of American Express card that routinely allow carrying a balance.

As the most widely held type of card, bankcards hold particular importance in any examination of family finances. Indeed, balances on such cards accounted for 84.9 percent of outstanding credit card balances in 2004, up from 82.1 percent in 2001. As reflected in the overall movement for credit cards from 2001 to 2004, the proportion of bankcard holders who had a balance went up 2.5 percentage points, to 56.2 percent; the proportion of bankcard holders who reported that they usually pay their balances in full was about unchanged in 2004 at 55.7 percent. For the month preceding the interview, the median charge

41. The remaining diseussion of eredit cards cxcludes rewolving store accounts that are not tied to a crectil card. In 2004,60 percent (5.5 percent in 2001 ) of lamilies hat such an account, the median outstanding balanes for families that had a balance was $\$ 700$ ( $\$ 600$ in 2001). and the total of such balaness ascounted for 4.3 percent (5.2 percent in 2061) of the total of balances on credil carck and such store accounts (tata not shown in the tables). on all bank-type cards held by the family rose slightly over the recent three-year period, from $\$ 210$ in 2001 to $\$ 250$ in 2004 . For families having any bank-type cards, the median number of such cards remained at 2; the median credit limit on all such cards rose 26.2 percent, to $\$ 13,500$; and the median interest rate on the card with the largest balance (or on the newest card, if there were no outstanding balances) fell 3.5 percentage points, to 11.50 percent.

\section{Other Debt}

From 2001 to 2004 , the proportion of families that held other types of debt edged up 0.4 percent, to 7.6 percent ${ }^{42}$ In $2004,0.5$ percent of families had a margin loan, 3.5 percent had a loan against a pension from a current job of the family head or that person's spouse or partner, 1.6 percent had a loan against a cash value life insurance policy, and 2.7 percent had another miscellaneous type of loan (data not shown in the tables).

The use of other debt is spread broadly across demographic groups, but rates of use are notably lower for families headed by those who are 65 years of age or older and by those who are retired. Across income groups, use of such debt fell from 2001 to 2004 only for the lowest group. The median amount owed by families with this type of debt rose 25.0 percent, to $\$ 4,000$, between 2001 and 2004 ; over the same time, the mean fell 9.0 percent. In 2004, 50.4 percent of the total amount of this type of debt was attributable to margin loans, 21.2 percent to loans against a pension from a current job of the family head or that person's spouse or partner, 9.8 percent to loans against cash value life insurance policies, and the remaining 18.7 percent to miscellaneous loans (data not shown in the tables).

\section{Reasons for Borrowing}

The SCF provides information on the reasons that families borrow money (table 12). One subtle problem with the use of these data is that, even though money is borrowed for a particular purpose, it may be employed to offset some other use of funds. For example, a family may have sufficient funds to purchase a home without using a mortgage but may

42. The "other debt" eategory comprises loans on cash walue life insuranes policiss, loans against pension acounts, borrowing on margin accounts, and a miscellaneous category largely comprising personal loans not explicilly calegorized elsewhere. 
12. Amount of debt of all families, distributed by purpose of debt, 1995-2004 surveys

Pistient

\begin{tabular}{|c|c|c|c|c|}
\hline I'urpose al' ditht & 1995 & 1998 & $2 i i i l$ & 20014 \\
\hline \multicolumn{5}{|l|}{ F'rimary residlence } \\
\hline |'urchinise ....... & 70.3 & 67.9 & 70.4 & 701.2 \\
\hline Improvement & 2.1) & 2.1 & 201 & 1.8 \\
\hline OLhar residential preperty ... & 8.2 & 7.8 & 6.5 & 9.5 \\
\hline Investments excluding real estate & 1.1) & 3.3 & 2.8 & 2.2 \\
\hline 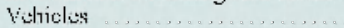 & 76 & 7.6 & $7 . \AA$ & 6.7 \\
\hline Gidods and senvices & 5.7 & 6.3 & 5.8 & 6.0 \\
\hline Education $\ldots \ldots . . .$. & 2.7 & 3.5 & 3. 1 & 3.0 \\
\hline Inelissif fiable loams against & 3 & 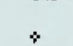 & $*$ & $\Leftrightarrow$ \\
\hline 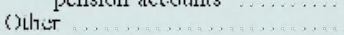 & 2.2 & 1.5 & 1.1 & 6 \\
\hline Total & $1101)$ & 1(II) & 1(II) & 1010 \\
\hline
\end{tabular}

Note: See note to table 7

l'Less than $1 .(15$ percent.

instead choose to finance the purchase to free existing funds for another purpose. Thus, trends in the data can only suggest the underlying use of funds by families.

Although the survey information on use is substantial, it is not exhaustive. Most importantly, for the case of credit cards it was deemed impractical to ask about the purposes of borrowing that might well be heterogeneous for individual families. For the analysis here, all credit card debt is included in the category "goods and services." The surveys before 2004 lack information on the use of funds borrowed through a first-lien mortgage; therefore, for purposes of this calculation, all funds owed on a first-lien mortgage on a primary residence are assumed to have been used for the purchase of the home, even when the homeowner has refinanced and extracted equity.

The great majority of family debt is attributable to the purchase of a primary residence; from 2001 to 2004, the share of debt for this purpose declined a fraction of a percentage point. Borrowing for residential real estate other than a primary residence, the second-largest purpose for borrowing, rose notably. The share of borrowing for vehicles, the third-largest share, fell 1.1 percentage points. The shares of borrowing for other purposes held about steady.

\section{Choice of Lenders}

The survey provides information on the types of lender to which families owe money at the time of the interview (table 13). The share of total family debt held by thrift institutions - savings and loan institutions and savings banks-rose 1.2 percentage points from 2001 to 2004 , reversing a previous trend; the 1.4 percentage point increase in the share for real estate or mortgage lenders continued an earlier pat-
13. Amount of debt of all families, distributed by type of lending institution, 1995-2004 surveys Percent1

\begin{tabular}{|c|c|c|c|c|}
\hline Type of institution & 1955 & 1098 & 2)(11 & $2131) 4$ \\
\hline Ciommercial bank & 34.9 & 32.8 & 34.1 & 35.1 \\
\hline 'Ihorilì instilutism' & 10.8 & 97 & 6.1 & 7.3 \\
\hline Credit union $\ldots . . . . . . .$. & 4.5 & 4.3 & 5.5 & 3.65 \\
\hline Finamec or lom company & 3.2 & 4.1 & 4.3 & 4.1 \\
\hline Brokerage ................ & 1.0 & 3.8 & 3.1 & 2.5 \\
\hline Mortacage ar reil entate lender & 32.8 & 35.6 & $38 . i$ & 39.4 \\
\hline Indivitual lenter $\ldots \ldots \ldots \ldots$ & $5.1)$ & 3.3 & 2.0 & 1.7 \\
\hline Other nontinancial & .8 & 1.3 & 1.4 & 2.1) \\
\hline 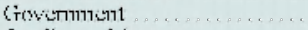 & 1.2 & 6 & 1.1 & .7 \\
\hline Credit card issuer & 3.9 & 3.5 & 3.7 & 3.1) \\
\hline 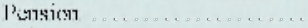 & .2 & 4 & .3 & .3 \\
\hline Other .... & .7 & 3 & .5 & .2 \\
\hline 'listil & 1ill & lilil & $10 i 1$ & $10 i 1$ \\
\hline
\end{tabular}

1. Savingess and loan association or savingess bank.

tern. The share for commercial banks moved up 1.0 percentage point, while the share for credit unions fell 1.9 percentage points. Other smaller changes accounted for the rest of the pattern of changes in 2004

In some cases, loans may have been held at the time of the interviews by institutions other than the ones that originally made the loans. Resale of loans is particularly important for mortgage debt. According to the 2004 survey, 41.5 percent of the first-lien mortgages on primary residences were held by lenders other than the ones that made the original loans, a figure only slightly changed from $2001 .{ }^{43}$ In dollarweighted terms, the results are similar; mortgages with non-originating lenders account for 43.3 percent of the outstanding balances on first-lien mortgages for primary residences in 2004 (data not shown in the tables).

\section{Debt Burden}

The ability of individual families to service their loans is a function of two factors: the level of their loan payments and the income and assets they have available to meet those payments. In planning their borrowing, families make assumptions about their future ability to repay their loans. Problems may occur when events turn out to be contrary to those assumptions. If such misjudgments are sufficiently large and prevalent, a broad pattern of default,

43. Mortgages and other loans may also be serviced by an instilution other than the current lender, and some respondents may mistakcnly report their loan as having becn sold even though it is simply being scrviced by an institution other than the eurrent lender. Because a loan can also be sold withoul changing the servicer, some borrowers may mistakenly report that their loan has not been solt. 
restraint in spending, and financial distress in the wider economy might ensue.

From the third quarter of 2001 to the same period in 2004, inflation-adjusted aggregate household debt reported in the Federal Reserve's flow of funds accounts increased 26.3 percent ${ }^{44}$ At the same time, income was relatively flat, and interest rates tended to be lower at the end of the period. The typical contract periods of various types of loan appear to have been largely unchanged, but borrowers may have substituted longer-term home-secured debt for other debts that typically have shorter contract periods. Thus, whether the growth in debt translated into a change in families' ability to service their debts is not clear a priori. The net consequences of these movements on the ratio of payments to income can only be assessed by looking at how these factors vary together over families.

The Federal Reserve staff has constructed an aggregate-level debt service ratio, defined as an estimate of total scheduled loan payments (interest plus minimum repayments of principal) for all households, divided by disposable personal income. From the third quarter of 2001 to the same period in 2004, the aggregate-level measure edged up about 0.4 percentage point, to 13.2 percent. $^{45}$

The survey data may be used to construct a similar estimate of the debt-burden ratio and to construct such an estimate for various demographic groups (table 14). ${ }^{46}$ The SCF-based estimate is the ratio of

44. See hup iww lederalreserve govireleases 7.1 : Current.

45. Data on this measure, the "debt service ratio;" and a description of the series are awailable at watederalreservegovireleases housedebtidefault.htm. See Karen Dywan, Katlleen Johnson. and Karen Pence (2003). "Recent Changes to a Measure of' t.S. Household Debl Service," Ftoftrat Rosorve Bullotirs, vol. 89 (October). pp. 45160 .

46. The survey measure of payments relative to income may diller from the aggregate-level measure for seteral reasons. First, the debt paynents included in cach nuasure are different. The aggregate-level neasure includes only debts originated by depositorics. finance coinpanies, and other financial institutions, whereas the surtey includes, in principle. debts from all sourees.

Second, the aggregate-level incasure uscs a NIPA estinuate of disposable personal income for the period concurrent with the estimated paymenis as the denominator of the ralio, whereas the survey neasure uses total before-tax incone reported by survey fanilics for the preceding year; the differenees in these two incone ineasures are complex.

Third, the payments in the aggregate-level incasure are estimated using a formula that entails conplex assumptions about minimum payments and the distribution of loan tems at any given tince; the survey measure of paynents is directly asked of the survey respondents but may also include payments of taxes and insuranee on real estale loans.

Fouril, because the survey measures of payments and income are based on the responses of a sample of respondents, they may be aftected both by sampling cror and by various types of response cror: As mentioned earlier in this article the survey income measure tracks the mosi comparable measure of income in the Census Bureatis total debt payments for all families to total family income of all families. From 2001 to 2004, the SCFbased estimate rose more than the aggregate-level measure, increasing 1.5 percentage points, to 14.4 percent; in the previous three-year period, the SCF measure had declined while the aggregate-level measure had risen. If total payments and incomes are computed from the survey data using only families with debt payments, the results for the recent period show a slightly larger increase, from 16.0 percent in 2001 to 17.7 percent in 2004; if the ratio is computed using only families with home-secured debt, the data show a rise from 18.2 percent in 2001 to 20.1 percent in 2004 (data not shown in the tables).

The ability to look at the distribution of payments relative to income at the level of families potentially offers insights that are not available from any of the aggregate-level figures. In particular, the survey allows a detailed look at the spectrum of payments relative to income across all families with debts. Over the recent period, the median of the ratios for individual families that had any debt rose 1.3 percentage points, to 18.0 percent, in 2004; the increase reversed a 1.2 percentage point decline in the ratio over the preceding three years. The median also rose at least slightly in the recent period for all demographic groups shown except for the 65-74 age group and renters, for which groups the ratio fell slightly. ${ }^{47}$

A limitation of the median ratio is that it may not be indicative of distress because it reflects the situation of only a typical family. Unless errors of judgment by both families and lenders are pervasive, one would not expect to see signs of financial distress at the median. Thus, a more compelling indicator of distress is the proportion of families with unusually large total payments relative to their incomes. From 2001 to 2004 , the proportion of debtors with payments exceeding 40 percent of their income edged up 0.4 percentage point, to 12.2 percent; in the preceding three years, the proportion had fallen 1.8 percentage points. The survey shows an interesting pattern of increases and decreases in the proportion of families with debt that had relatively high payments across demographic groups in the recent three-year period. The share fell for families in the lowest and the two highest income and wealth groups and for

Current Population Survey. Over the 2001-04 period, however, the SCF shows more growth in the aggregate level of debt than the licderal Rescrve's flow of funds accounts; timing and conceptual dillerences may explain some of the dillerence. Finally, the survey measure excludes tebt payments of household members who are not menters of the fanily unit analyzed in this article.

47. The nedian of the ratio for families with lone-sceured debt in 2004 was 24.2 percent. up lirom 22.2 percent in 20061 (datal nol shown in the lables). 
14. Ratio of debt payments to family income (aggregate and median), share of debtor families with ratio greater than 40 percent, and share of debtors with any payment past due sixty days or more, 1995-2004 surveys Perét

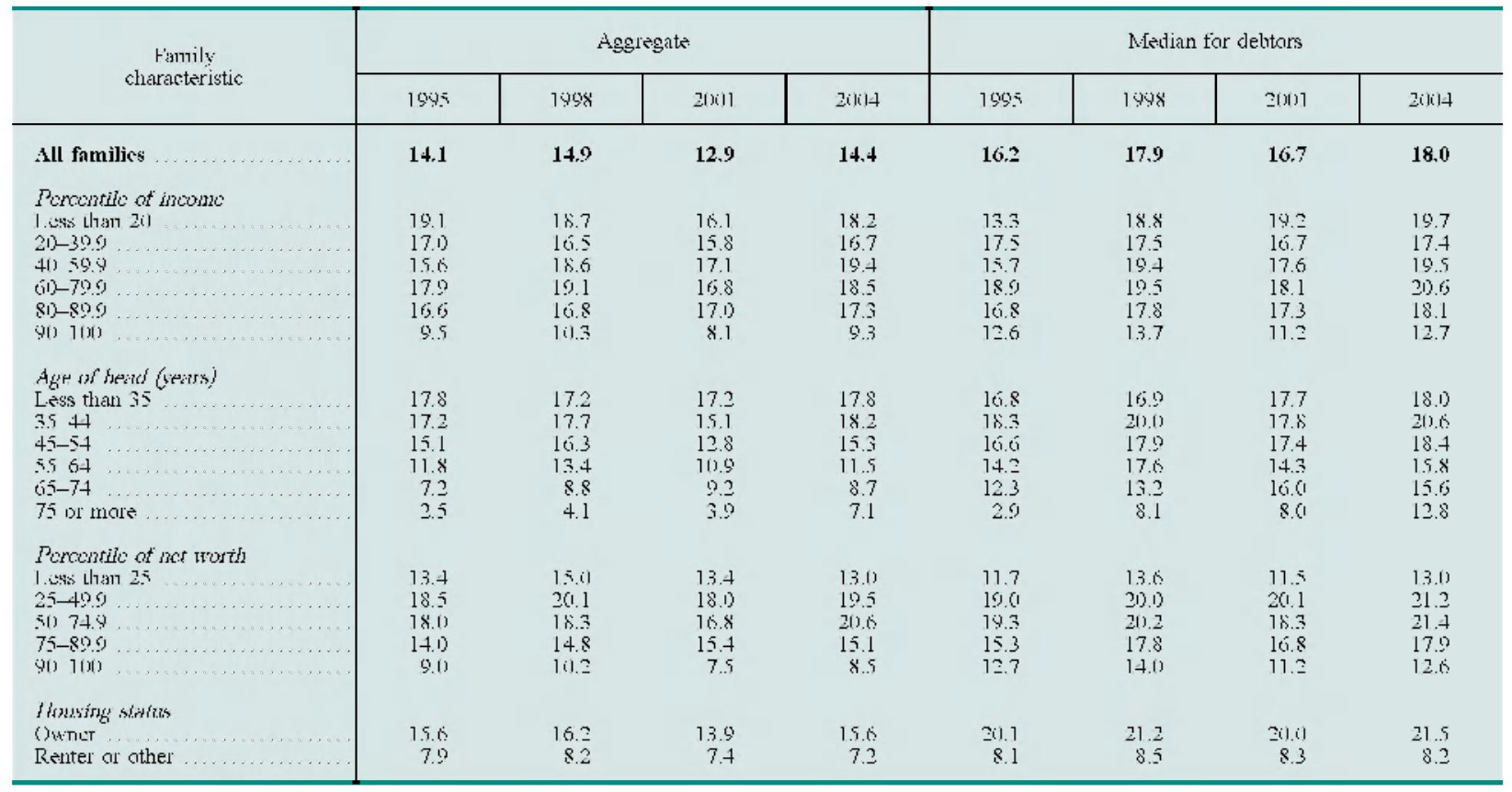

NoTE: The aggregate measure is the ratio of total debt payments to total income for all families. The median is the median of the distribution of ratios calculated for individual families with debt. Also see note to table 1 .

families headed by persons older than 55; it rose for the middle of the income and wealth distributions and for younger families. Both for homeowners and for renters, the proportion with high payments was only slightly changed. ${ }^{48}$

Other commonly used indicators of debtrepayment problems are aggregate delinquency rates, that is, the number of delinquent accounts or the percentage of total balances on which payments are late. The measures based on numbers of delinquent accounts tend to show increases or small declines over the recent three-year period, while the measures based on dollar volumes show a decline. ${ }^{49}$

A related measure is collected in the SCF. Families that have any debt at the time of their interview are

48. Of familiss with hons-sceured debt, the proportion that had total payments of more than 46 percent of their income was 17.1 persent in 2004 , a figure virtually unchanged from that in 2001 (data not shown in the tables).

49. Several measures of credil delincluency are commonly used. Data from lhe Call Report and Koody's Investors Service are based on dollar volumes of delinquent loans. Those data suggest that delincuencies generally declined between 2001 and 2004 on credit carcls. on closed-end consumer credil, and on morlgages. Over the same period, howewer, data from the American Bankers Association on numbers of delinquent acoounts show a smaller decline in delinquencies for closed-end consumer loans, litile change for morlgages, and an increase for credil cards. asked whether they have been behind in any of their payments in the preceding year. This measure differs conceptually from the aggregate delinquency rates in that the survey counts multiple occasions of late payments as one, counts families instead of balances or accounts, and includes all types of loan; because it counts individual families, not their balances, it is closer in spirit to aggregate measures based on the numbers of delinquent accounts than to those based on the amounts of delinquent balances. Over the 2001-04 period, the survey shows an increase of 1.9 percentage points in the proportion of debtors who were sixty or more days late with their payments on any of their loans in the preceding year, to 8.9 percent. This measure showed increases for all the demographic groups except for the highest two income groups, for the third quartile and highest decile of the wealth distribution, and for families headed by persons aged 55-64. ${ }^{50}$ Some of the largest increases were seen by groups that had more modest or even negative changes in the other survey-based measures of debt burden.

50. lior families with home-secured debt. the result is very similar to that for homeowners owerall. The proportion with payments late sixly days or more in 2004 was 5.7 percent, up from 4.5 percent in 2001 (data not shown in the tables). 
14.-Continued

\begin{tabular}{|c|c|c|c|c|c|c|c|c|}
\hline \multirow{2}{*}{$\begin{array}{l}\text { ramily } \\
\text { characteristic }\end{array}$} & \multicolumn{4}{|c|}{ Deltosss with ratio greater than 41) percent } & \multicolumn{4}{|c|}{ Deltors with any payment past due sixty days or more } \\
\hline & 1905 & 1998 & $20 i 11$ & $2 i i i 4$ & 1995 & 1398 & $20(0)$ & $2 i i j 4$ \\
\hline All families & 11.7 & 13.6 & 11.8 & 12.2 & 7.1 & 8.1 & 7.0 & 8.9 \\
\hline 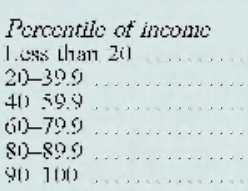 & $\begin{array}{r}27.5 \\
18.1 \\
9.9 \\
7.7 \\
4.7 \\
2.3\end{array}$ & $\begin{array}{r}29.9 \\
18.3 \\
1.58 \\
5.8 \\
3.5 \\
2.8\end{array}$ & $\begin{array}{r}29.3 \\
15.65 \\
12.3 \\
65.5 \\
3.5 \\
2.0\end{array}$ & $\begin{array}{r}27.6 \\
18.65 \\
1.7 .7 \\
7.1 \\
2.4 \\
1.8\end{array}$ & $\begin{array}{r}11.2 \\
1(1.1 \\
8.7 \\
6.6 \\
2.8 \\
1.11\end{array}$ & $\begin{array}{r}12.9 \\
12.3 \\
160.0 \\
5.0 \\
3.0 \\
1.6\end{array}$ & $\begin{array}{r}13.4 \\
11.7 \\
7.9 \\
4.1 \\
2.6 \\
1.3\end{array}$ & $\begin{array}{r}1.5 .9 \\
13.8 \\
10.4 \\
7.1 \\
3.3 \\
.3\end{array}$ \\
\hline 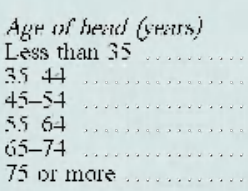 & $\begin{array}{r}12.1 \\
9.9 \\
12.3 \\
1.5 .1 \\
11.3 \\
7.4\end{array}$ & $\begin{array}{l}12.8 \\
12.5 \\
12.5 \\
14.01 \\
18.1 \\
21.4\end{array}$ & $\begin{array}{l}12.1) \\
10.1 \\
11.6 \\
12.3 \\
14.7 \\
14.65\end{array}$ & $\begin{array}{l}12.8 \\
12.6 \\
13.1 \\
10.2 \\
11.65 \\
11.7\end{array}$ & $\begin{array}{l}8.7 \\
7.7 \\
7.4 \\
3.2 \\
5.3 \\
5.4\end{array}$ & $\begin{array}{r}11.1 \\
8.4 \\
7.4 \\
7.5 \\
3.1 \\
1.1\end{array}$ & $\begin{array}{r}11.5 \\
5.9 \\
6.2 \\
7.1 \\
1.5 \\
.8\end{array}$ & $\begin{array}{r}13.7 \\
11.7 \\
7.6 \\
4.2 \\
3.4 \\
3.9\end{array}$ \\
\hline 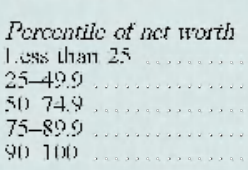 & $\begin{array}{r}10.1 \\
12.0 \\
12.7 \\
0.0 \\
11.6\end{array}$ & $\begin{array}{l}13 . i \\
15.0 \\
13 . i \\
12.2 \\
12.4\end{array}$ & $\begin{array}{r}11.6 \\
14.1 \\
11.3 \\
11.7 \\
8.5\end{array}$ & $\begin{array}{r}10.6 \\
15.8 \\
12.8 \\
9.6 \\
7.6\end{array}$ & $\begin{array}{r}14.5 \\
8.2 \\
4.4 \\
2.4 \\
.7\end{array}$ & $\begin{array}{r}16.1 \\
9.8 \\
5.5 \\
1.17 \\
2.4\end{array}$ & $\begin{array}{r}17.7 \\
7.2 \\
3.6 \\
.7 \\
.3\end{array}$ & $\begin{array}{r}22.9 \\
11.10 \\
3.2 \\
1.1 \\
.1\end{array}$ \\
\hline $\begin{array}{l}\text { Sisusirng sinfins } \\
\text { Ouner } \\
\text { Renter or other }\end{array}$ & $\begin{array}{r}14.3 \\
5.8\end{array}$ & $\begin{array}{r}16.5 \\
6.4\end{array}$ & $\begin{array}{r}14.7 \\
4.2\end{array}$ & $\begin{array}{r}14.9 \\
4.4\end{array}$ & $\begin{array}{r}5.1 \\
11.5\end{array}$ & $\begin{array}{r}6.1 \\
12.8\end{array}$ & $\begin{array}{r}4.3 \\
14.1\end{array}$ & $\begin{array}{r}5.6 \\
18.65\end{array}$ \\
\hline
\end{tabular}

\section{SUMMARY}

Data from the SCF show that despite small changes in real family income over the 2001-04 period-an increase of 1.6 percent in the median and a decline of 2.3 percent in the mean-families overall still saw some increase in their net worth. The median value of net worth rose 1.5 percent, while the mean rose more- 6.3 percent. However, the measured gains in wealth in the 2001-04 period pale in comparison with the much larger increase of the preceding three years; from 1998 to 2001, median net worth rose 10.3 percent and the mean 28.7 percent. In the more recent period, median wealth declined for families in the bottom 40 percent of the income distribution and rose for those higher in the distribution; in contrast, mean net worth rose or held about steady for all income groups.

In the three years after the 2001 survey, interest rates moved generally lower; indexes of equity market performance trended generally downward over the early part of the period but made up the losses with gains in 2004; and residential real estate appreciated strongly. Against this backdrop, the overall share of financial assets in families' portfolios, as defined in this article, declined despite substantial gains in holdings for some groups. Of particular note, the share of families that held stocks either directly or indirectly through an account-type retirement plan or another type of managed asset account fell to about 49 percent in 2004 after having reached an SCF high of almost 52 percent in 2001.

Logically balancing the decline in the share of financial assets in families' portfolios was the rise in the share of their nonfinancial assets. The most important factor in this rise was residential real estate. The homeownership rate went up 1.4 percentage points, and the ownership rate for other residential real estate (including both second homes and investment properties) went up 1.2 percentage points. At the same time, the value of real estate increased dramatically in many areas.

Overall, asset ownership and debt use increased in both prevalence and amount. The net effect was an increase in the proportion of families' assets offset by debts-from about 12 percent in 2001 to 15 percent in 2004. The most important factor in the increase was a rise in the amount of debt associated with residential real estate. The amount of other types of debt also rose.

Even with interest rates lower in 2004 than in 2001, the SCF data show a moderate increase in measures of debt burden. The period saw increases in the proportion of families that had been delinquent with their payments in the year preceding the survey and in the median ratio of loan payments to family income. The increase in delinquencies was somewhat less broadly spread across demographic groups than 
was the increase in the median ratio. At the same time, the proportion of families with high values of the ratio was only marginally higher.

\section{APPENDIX: SURVEY PROCEDURES AND STATISTICAL MEASURES}

Detailed documentation of the SCF methodology is available elsewhere. ${ }^{51}$ The 2004 data used here are derived from the final internal version of the survey information. Data from this survey, suitably altered to protect the privacy of respondents, along with additional tabulations of data from the surveys beginning with 1989 , will be available in February 2006 on the Federal Reserve's website at www.federalreserve.gov/ pubs/oss/oss2/scf2004home.html. Links to the data used in this article for earlier periods are available on that site. Results reported in this article for earlier surveys may differ from the results reported in earlier articles because of additional statistical processing, correction of data errors, revisions to the survey weights, conceptual changes in the definitions of variables used in the articles, and adjustments for inflation.

As a part of the general reconciliations required for this article, the survey data were compared with many external estimates, a few of which are mentioned in the text. Generally, the survey estimates correspond fairly well to external estimates. One particularly important comparison is between the SCF and the Federal Reserve's flow of funds accounts for the household sector. This comparison suggests that when the definitions of the variables in the two sources can be adjusted to a common conceptual basis, the estimates of totals in the two systems tend to be close. The data series in the SCF and in the flow of funds accounts usually show very similar growth rates. ${ }^{52}$ In general, the data from the SCF can be compared with those of other surveys only in terms of the medians because of the special design of the SCF sample.

51. Sec Arthur L3. Kennickell (2000). "Wealth Measurement in the Survey of Consuner linanes: Methodology and Direstions for liuture Research" (Washington: Board of Governors of the Federal Reserve Systen. Hay): Arthur B. Konnickell (2001). "Modeling Wealth with Multiple Observations of lncone: Redesign of the sample for the 2001 Survey of Consumer Finances" (Washington: Board of Crovernors ol the Federal Reserve System, October), www Tederalreserve gowi pubs oss oss 2 method.1ntml; and reforenees sited in these papers.

52. For details on how these comparisons are struclured and the results of comparisons lor earlier surveys, sec Roshelle $I_{\text {. }}$ Antonicwicz (2000), " $A$ Comparison of llow of liunds $A$ cocounts and the Surtey of Consuner linances" (Hashington: Board of Governors of the Federal Reserve System, October), www. lederalreservegovi pubsiossioss 2 imethod.htmi.

\section{Definition of "Family" in the SCF.}

The definition of "family" used throughout this article differs from that typically used in other government studies. In the SCF, a household unit is divided into a "primary economic unit" (PEU) the family - and everyone else in the household. The PEU is intended to be the economically dominant single individual or couple (whether married or living together as partners) and all other persons in the household who are financially interdependent with that economically dominant person or couple.

This report also designates a head of the PEU, not to convey a judgment about how an individual family is structured but as a means of organizing the data consistently. If a couple is economically dominant in the PEU, the head is the male in a mixed-sex couple and the older person in a same-sex couple. If a single individual is economically dominant, that person is designated as the family head in this report.

\section{Racial and Ethnic Identification}

In this article, the race and ethnicity of a family in the SCF are classified according to the self-identification of that family's original respondent to the SCF interview. The questions underlying the method of classification used in the survey were changed in both 1998 and 2004. Starting in 1998, SCF respondents were allowed to report more than one racial identification; in surveys before then, only one response was recorded. For maximum comparability with earlier data, respondents reporting multiple racial identifications were asked to report their strongest racial identification.

Beginning with the 2004 survey, the question on racial identification is preceded by a question on whether respondents consider themselves to be Hispanic or Latino in culture or origin; previously, such ethnic identification was captured only to the extent that it was reported as a response to the question on racial identification. The sequence of these two questions in the 2004 SCF is similar to that in the CPS. When families in the March 2004 CPS are classified in the way most compatible with the SCF, the proportion of Hispanic families is 10.5 percent; the 2004 SCF estimate is 11.2 percent. Differences in these proportions are attributable to sampling error and possibly to differences in the wording and context of the questions.

For greater comparability with the earlier SCF data, the data reported in this article ignore the infor- 
mation on ethnic identification available in 2004, but respondents reporting multiple racial identifications in the surveys starting with 1998 are classified as "nonwhite or Hispanic." For the 1995 survey, only the single recorded response to the racial classification question is used to classify families. In the 2004 $\mathrm{SCF}, 2.3$ percent of respondents reported more than one racial identification, up from 1.5 percent in 2001. Of those who responded affirmatively to the question on Hispanic or Latino identification in 2004, 85.7 percent also reported "Hispanic or Latino" as one of their racial identifications, and 82.1 percent reported it as their primary racial identification. Because the question on Hispanic or Latino ethnicity precedes the one on racial identification in the 2004 survey, the answer to the second of these two questions may have been influenced by the answer to the first. ${ }^{\text {is }}$

\section{The Sampling Techniques}

The survey is expected to provide a core set of data on family income, assets, and liabilities. The major aspects of the sample design that address this requirement have been constant since 1989. The SCF combines two techniques for random sampling. First, a standard multistage area-probability sample (a geographically based random sample) is selected to provide good coverage of characteristics, such as homeownership, that are broadly distributed in the population.

Second, a supplemental sample is selected to disproportionately include wealthy families, which hold a relatively large share of such thinly held assets as noncorporate businesses and tax-exempt bonds. Called the "list sample," this group is drawn from a list of statistical records derived from tax returns. These records are used under strict rules governing confidentiality, the rights of potential respondents to refuse participation in the survey, and the types of information that can be made available. Individuals listed by Forbes magazine as being among the wealthiest 400 people in the United States are excluded from sampling.

Of the 4,522 interviews completed for the 2004 $\mathrm{SCF}, 3,007$ were from the area-probability sample, and 1,515 were from the list sample; the figures for 2001 are 2,917 from the area-probability sample and 1,532 from the list sample. The 2004 survey repre-

53. For a rewien of the effects of warious approaches to measuring rase and cthnicity: sec Clyde Tucker, Ruth MeKay: Lrian Kojetin, Roderick Harrison, Manuel de la Puente, Jinda Stinson, and Fd Robinson (1996), "Testing Methods of Collecting Racial and F.thnic sents 112.1 million families, and the 2001 survey represents 106.5 million families. ${ }^{54}$

\section{The Interviews}

The survey questionnaire has changed in only minor ways since 1989, except in a small number of instances in which the structure was altered to accommodate changes in financial behaviors, in types of financial arrangements available to families, and in regulations covering data collection. In the 2004 survey, the most important changes were made in the way data are collected on pensions associated with current jobs and in the way information is solicited about the racial and ethnic identification of families. In these cases and in all earlier ones, every effort has been made to ensure the maximum degree of comparability of the data over time. Except where noted in the article, the data are highly comparable over time.

The generosity of families in giving their time for interviews has been crucial to the SCF. In the 2004 $\mathrm{SCF}$, the median interview length was about eighty minutes. However, in some particularly complicated cases, the amount of time needed was substantially more than two hours. The role of the interviewers in this effort is also critical. Without their dedication and perseverance, the survey would not be possible.

The SCF interviews were conducted largely between the months of May and December in each survey year by NORC, a social science and survey research organization at the University of Chicago. The majority of interviews were obtained in person, although interviewers were allowed to conduct telephone interviews if that was more convenient for the respondent. In the surveys beginning with 1995, each interviewer used a program running on a laptop computer to administer the survey and collect the data.

The use of computer-assisted personal interviewing has the great advantage of enforcing systematic collection of data across all cases. The computer

Inlormation: Results ol the Current Population Survey Supplement on kase and lithnicity," BLS Statistical Notes 40. C'PS Publications (Washington: Lurcau of Labor Statistics, Junc), wrw bls.census.gov/ cps:racelhn 1995 istat40rp.him

54. In the development of weiglnts for the SCli. population estimates of the Bureal of the Census are a key input. $A$ fter the data for the 2001 SCF were processed, the Bureau of the Census allered its population estimates in a way that increases the number of family units relevant for the 2001 SCli to 108.2 million. Pending a more detailed investigation into the change in the population estimate, the $2001 \mathrm{SCF}$ estinales reported in this article are calculaled with weights based on the original. lower C'ensus population figure. The use of a different number of families does not affect the incdian and mean estimates reported in this article. The 1998 survey represents 102.6 million families, and the 1995 survey represents 99.0 million lamilies. 
program developed to collect the data for the SCF was tailored to allow the collection of partial information in the form of ranges whenever a respondent either did not know or did not want to reveal an exact dollar figure.

The response rate in the area-probability sample is more than double that in the list sample. In both 2001 and 2004, about 70 percent of households selected for the area-probability sample actually completed interviews. The overall response rate in the list sample was about 30 percent; in the part of the list sample likely containing the wealthiest families, the response rate was only about 10 percent.

\section{Weighting}

To provide a measure of the frequency with which families similar to the sample families could be expected to be found in the population of all families, an analysis weight is computed for each case accounting both for the systematic properties of the sample design and for differential patterns of nonresponse. The SCF response rates are low by the standards of other major government surveys, and analysis of the data confirms that the tendency to refuse participation is highly correlated with net worth. However, unlike other surveys, which also almost certainly have differential nonresponse by wealthy households, the SCF has the means to adjust for such nonresponse. A major part of SCF research is devoted to the evaluation of nonresponse and adjustments for nonresponse in the analysis weights of the survey ${ }^{55}$

\section{Sources of Error}

Errors may be introduced into survey results at many stages. Sampling error-the variability expected in estimates based on a sample instead of a census-is a particularly important source of error. Such error can be reduced either by increasing the size of a sample or, as is done in the SCF, by designing the sample to reduce important sources of variability. Sampling error can be estimated, and for this article we use replication methods to do so.

Replication methods draw samples, called replicates, from the set of actual respondents in a way that incorporates the important dimensions of the original sample design. In the SCF, weights were computed for all the cases in each of the replicates ${ }^{56}$ For each statistic for which standard errors are reported in this article, the weighted statistic is estimated using the replicate samples, and a measure of the variability of these estimates is combined with a measure of the variability due to imputation for missing data to yield the standard error.

Other errors include those that interviewers may introduce by failing to follow the survey protocol or misunderstanding a respondent's answers. SCF interviewers are given lengthy, project-specific training to minimize such problems. Respondents may introduce error by interpreting a question in a sense different from that intended by the survey. For the SCF, extensive pretesting of questions and thorough review of the data tend to reduce this source of error.

Nonresponse- either complete nonresponse to the survey or nonresponse to selected items within the survey - may be another important source of error. As noted in more detail above, the SCF uses weighting to adjust for differential nonresponse to the survey. To address missing information on individual questions within the interview, the SCF uses statistical methods to impute missing data; the technique makes multiple estimates of missing data to allow for an estimate of the uncertainty attributable to this type of nonresponse.
55. The weights used in this article are adjusted for differential rates of nonresponse across racial and elhnic groups by homeownership status. See Arthur B. Kennickell (1999), "Revisions of the SCli Weighting tisthodology: Accounting for Racolithnicity and Ilomeownership" (Washington: lioard of Governors of the federal Reserve System, December), www. Federalreserve.govipubsiossoss 2 i method.lituml.
56. See Arthur B. Kennickell (2000). "Revisions to the Varianes Listimation Procedure for the SCl" " (Washington: Board of Governors of the Feteral Reserve System, Oclober), www lederalreserve.gov: puls:ossioss2:melhod.htıml. 